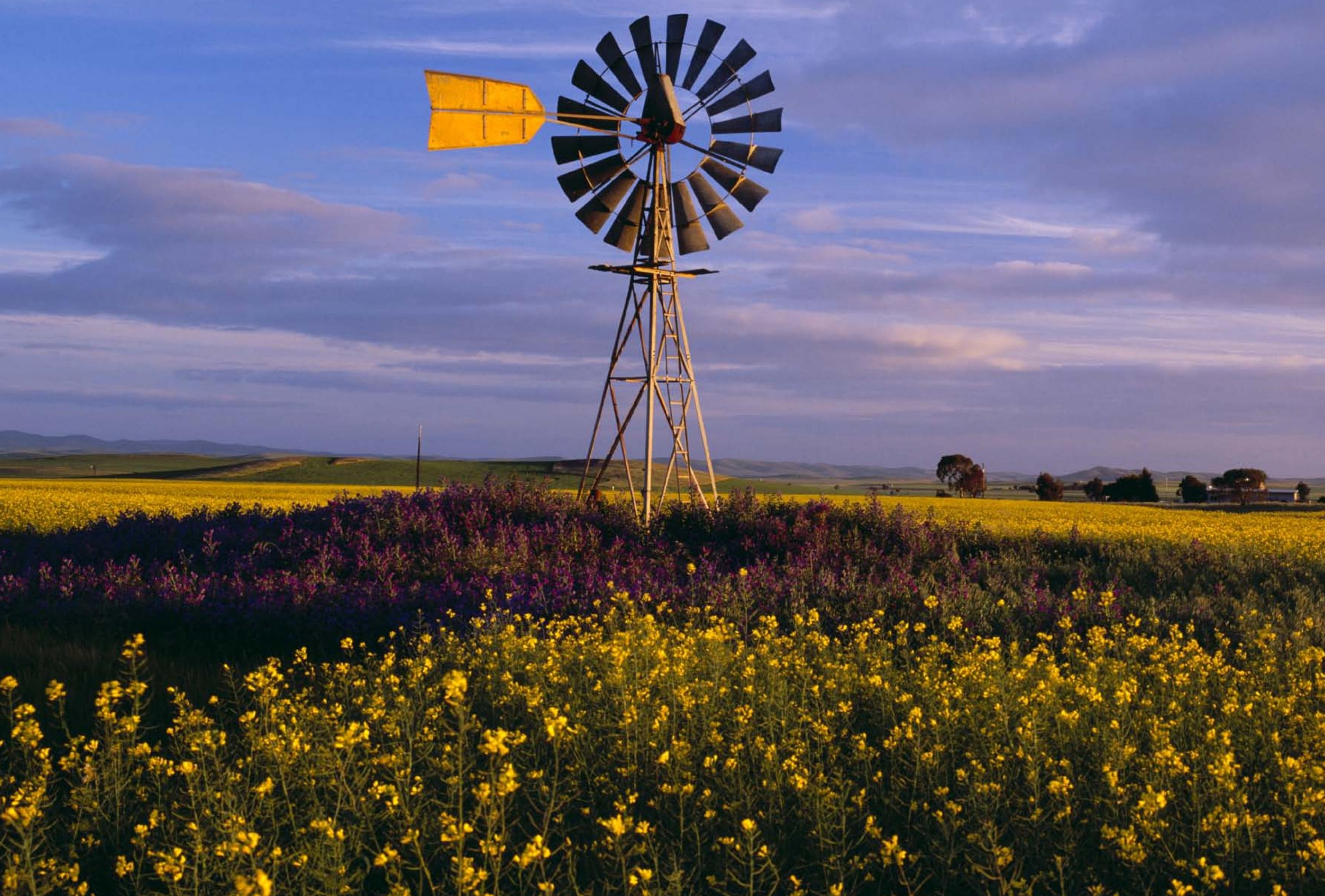




\section{Groundwater-lifeblood of the continent}

This chapter explores the journey of the development and use of Australia's groundwater resources, from the first Australians, to the frontier settlers, to the present day. Over this time, some $50 \mathrm{ka}$, the changes to groundwater systems in Australia have been profound. Water availability has shaped life and society in many ways, with aridity shaping the landscape and soils and determining where we live, grow our crops, raise animals and build our cities in this, the driest inhabited continent. Recognising the connections that groundwater can have with rivers, wetlands and ecosystems means understanding groundwater processes, and this, underpinned by the knowledge of geology, is fundamental to resolving many of Australia's natural resource management problems. Our understanding of these connections has improved, and emerging technologies have helped with management of Australia's groundwater for people, now and in the future.
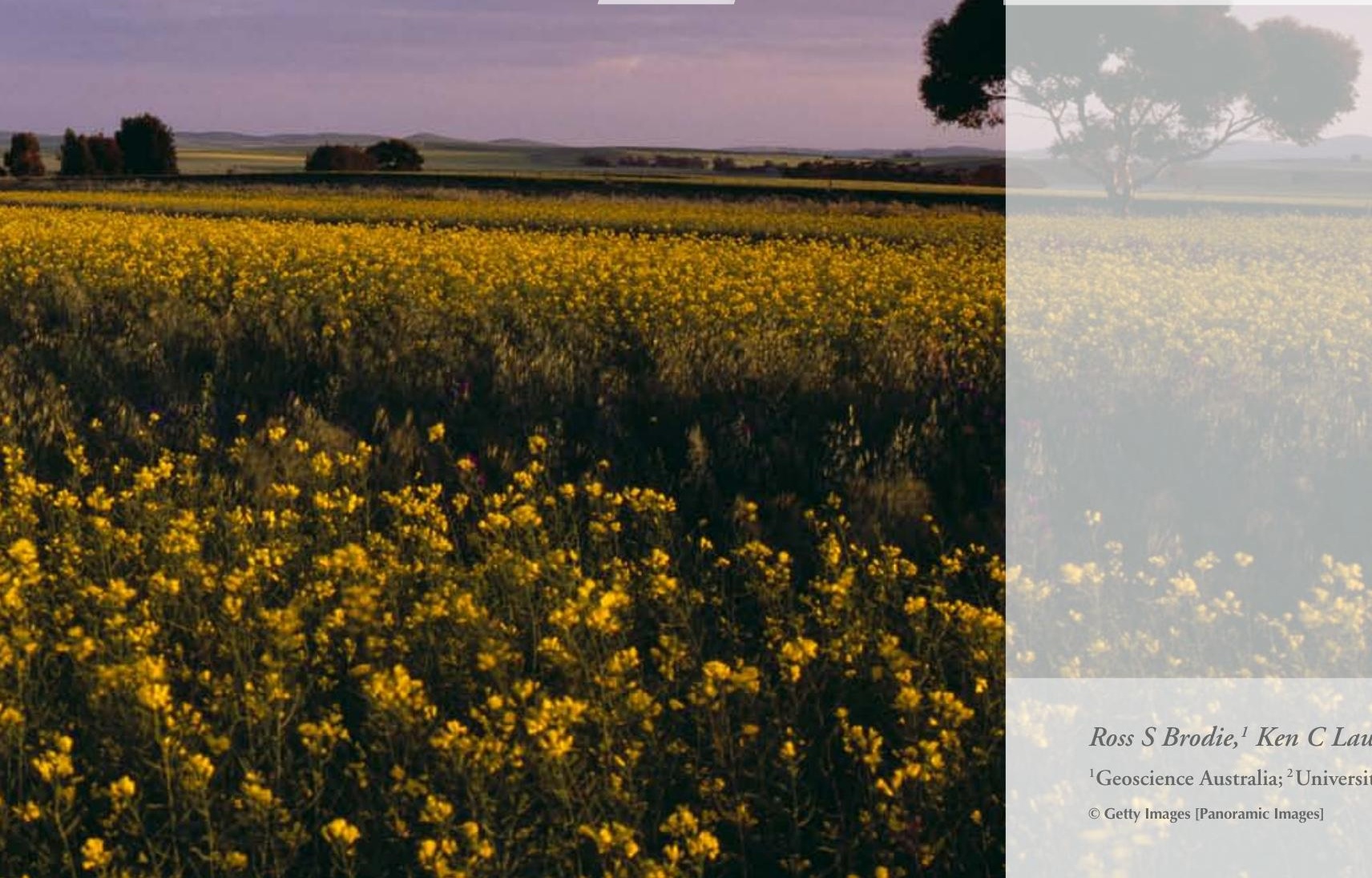

Ross S Brodie, ${ }^{1}$ Ken C Lawrie ${ }^{1}$ and D Philip Commander ${ }^{2}$

${ }^{1}$ Geoscience Australia; ${ }^{2}$ University of Western Australia

o Getty Images [Panoramic Images] 


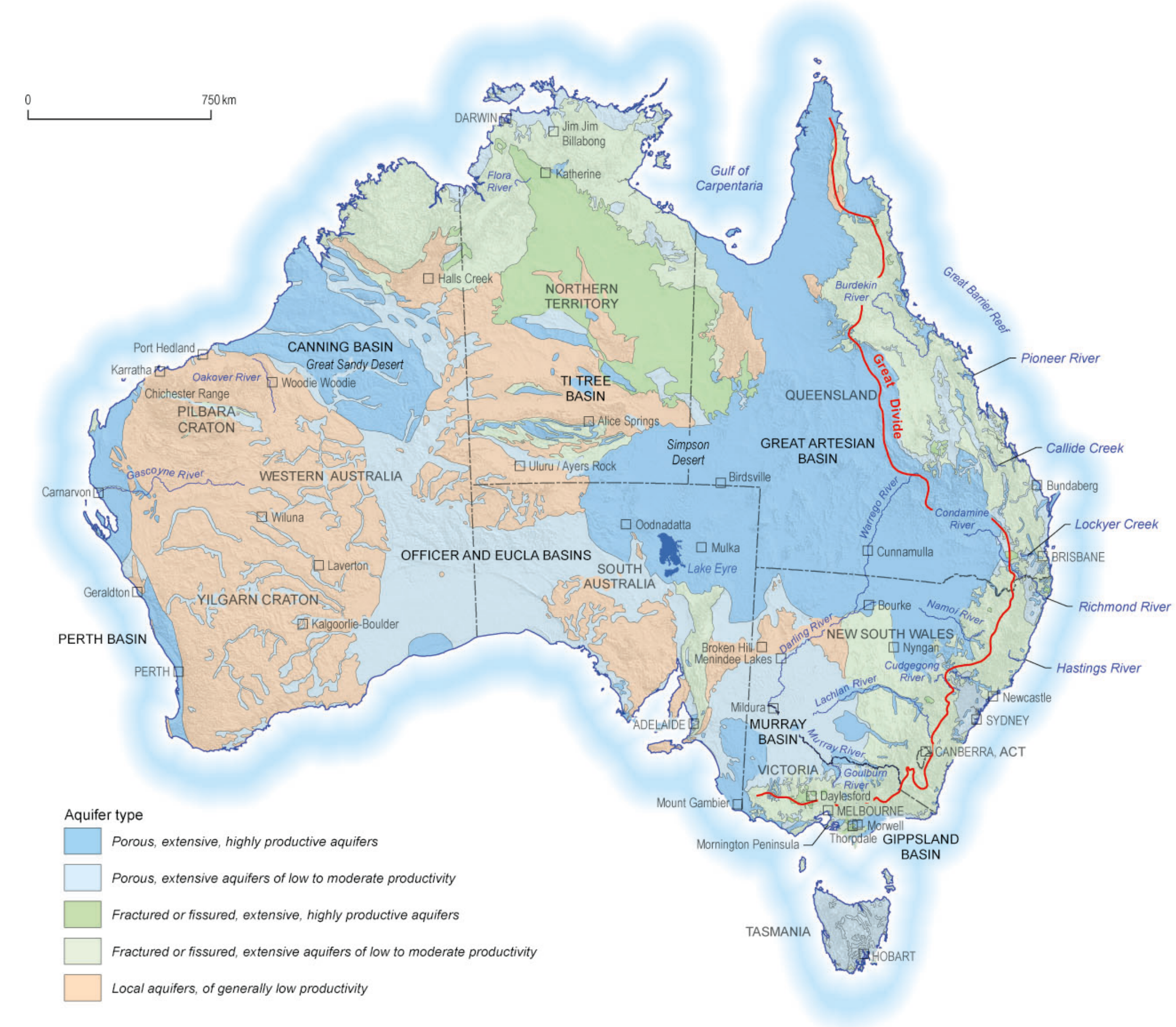




\section{Real dry}

In the driest inhabited continent, Australia's environment and people face the persistent challenge of securing water. Although groundwater may be less than one-fifth of the total accessible freshwater resource, it provides nearly a third of the water that is consumed. With a growing population and growing economy, this amount is increasing. Groundwater is the only source of water for many regional towns and remote Indigenous communities, and for many of the mining operations in the country's interior that underpin the national economy. Groundwater also provides almost a third of the high-security water that is vital for agriculture and towns during droughts. It could be said that groundwater is the lifeblood that sustains communities, industries and habitats, particularly during the tough times.

Geology, landscape and climate dictate the nature and extent of Australia's groundwater resources. The geological history (Chapter 2) provides the underlying architecture of aquifers and aquitards that define groundwater reservoirs and seals. The national hydrogeology map highlights the intrinsic relationship between the groundwater resource and the geological fabric (Figure 7.1).

What is groundwater? Groundwater is water that is found underground in cracks and pore spaces in soil and rock. There is a finite supply of water on Earth that is continually recycled naturally via the hydrological cycle (Figure 7.2). The hydrological cycle describes the constant movement of water above, on and below (groundwater) Earth's surface. Groundwater travels underground by percolation driven by gravity and pressure until the water-table intersects the ground surface. Water can then be discharged at springs or any other body of surface water (such as rivers, lakes and oceans). Once returned to the surface, this water can be used by plants, stored on the surface or evaporated. The percolation or flow of groundwater occurs through aquifers, which are bodies of permeable rock that can store and transmit significant quantities of water. Aquitards are bodies of less permeable rock that seal or contain groundwater resources or minimise the flow from an aquifer.

The ancient cratons of the Yilgarn and Pilbara (WA) tend to yield only limited groundwater from fractures and the weathered profile (Figure 7.1). Instead, the alluvial sands, gravels and calcretes associated with Cenozoic palaeodrainage tracking across the landscape provide the water supply for people, stock and mines. The sedimentary basins that border these cratons, such as the Canning, Officer and Eucla basins to the east, and the Perth and Carnarvon basins to the west, represent significant groundwater stores. In particular, the breakup of Gondwana and initiation of the Perth Basin in the Permian has left a legacy of extensive aquifers in a sedimentary pile up to $15 \mathrm{~km}$ thick in which freshwater can extend to depths of $2 \mathrm{~km}-\mathrm{a}$ fortunate resource for the state capital.

In central Australia, the consequences of the Ordovician Larapintine Seaway and subsequent deformation during the Devonian-Carboniferous Alice Springs Orogeny are reflected in the complex configuration of the Neoproterozoic to Devonian Amadeus, Georgina, Wiso, Daly and Ngalia basins (Figure 2.9). This further Gondwanan legacy
Figure 7.1: (opposite): National Hydrogeological Map of Australia, showing the type and productivity of the principal aquifer and the linkage with regional geology. The map also shows the key localities referred to in this chapter. The large dark-blue areas highlight significant groundwater resources in sedimentary basins, such as the Great Artesian Basin and the Canning Basin. Fractured rock aquifers, in the Yilgarn and Pilbara cratons in the west and along the Great Divide paralleling the eastern seaboard, tend to be local scale and of low-moderate productivity. Significant groundwater resources are hosted in largely Cenozoic alluvial deposits. (Source: Jacobson \& Lau, 1987) 


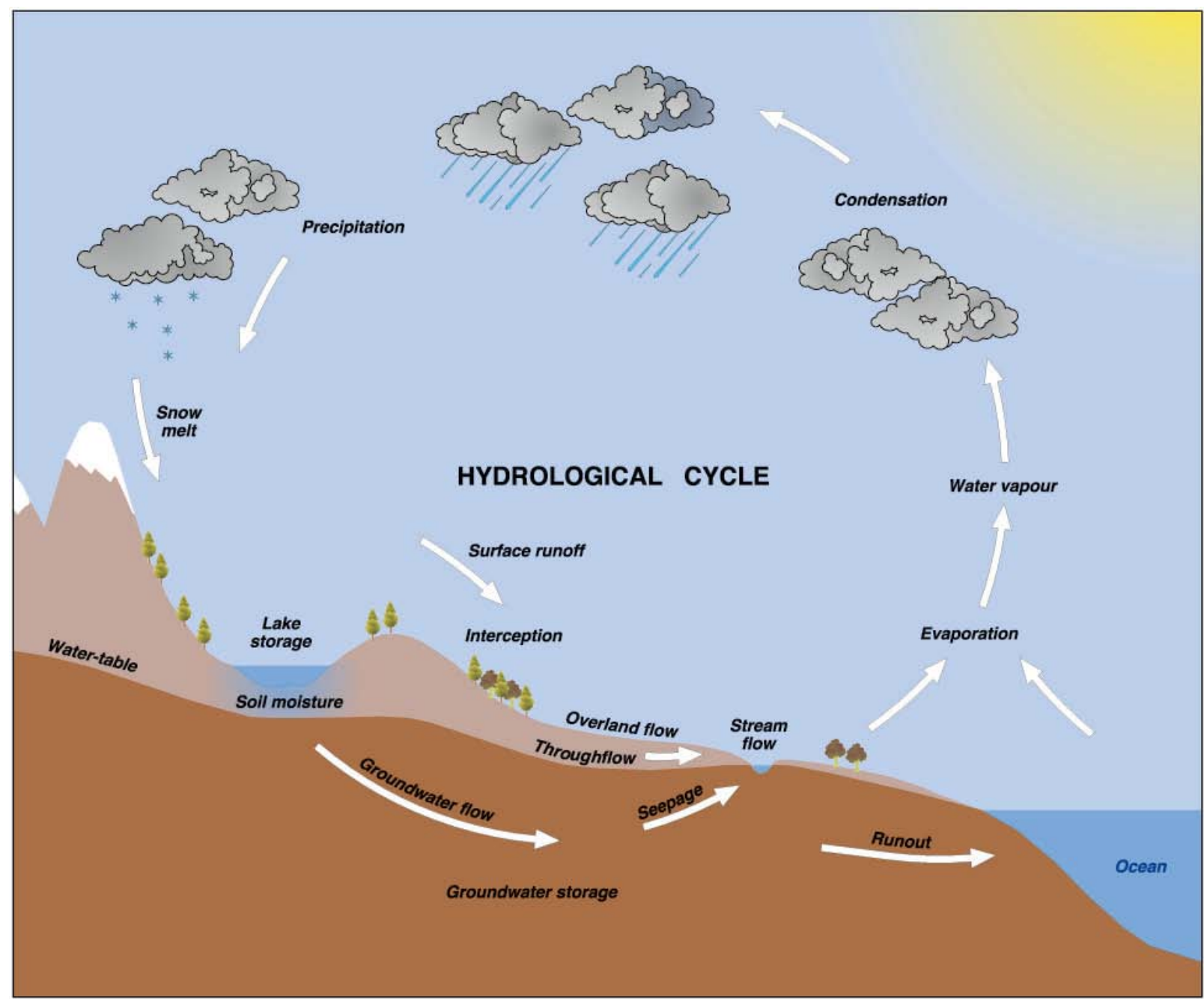

Figure 7.2: Hydrological cycle, showing the key role groundwater plays in the cycle. (Source: University of Texas) includes the Amadeus Basin, hosting the Mereenie Sandstone aquifer tapped by the Alice Springs borefield, and the principal karstic and fractured carbonate aquifers of the Daly Basin, the Oolloo Limestone and Tindall Limestone, which are used for stock, irrigation and town water supply, and provide important baseflow to the Daly River. In South Australia, the most productive aquifers are limestone found in Cenozoic basins such as the Otway and Murray.
In eastern Australia, the sheer size of the Great Artesian Basin dominates the National Hydrogeological Map (Figure 7.1). During the Jurassic, quartzose and volcanic detritus was deposited by major river systems, followed by marine sediments from the Early Cretaceous shallow sea (Box 4.3). The end product is a vast geological construct of extensive aquifers that crop out and receive recharge along the elevated basin margins, partnered with bounding aquitards that enable pressurised conditions and the blessing of flowing artesian water. In stark contrast, the patchwork of Paleozoic metamorphic, sedimentary and igneous rocks along the Great Divide tends to host relatively local-scale and low-yielding fractured rock aquifers (Chapters 2 and 5).

Dotted along the Great Divide is the chain of the Cenozoic mafic Newer Volcanic Group (Chapter 2), a legacy of continental drift over a mantle hotspot and valued for its combination of productive soils and aquifers. However, the true significance of the eastern highlands from a groundwater perspective is the rivers that drain from it. These include the Cenozoic alluvial aquifers of westerly flowing rivers, such as the Condamine, Namoi and Lachlan, and easterly flowing rivers, such as the Burdekin, Pioneer and Lockyer (Figure 7.1). Coastal sedimentary basin aquifers are also important in the east. For example, in the aquifers of the Gippsland Basin east of Melbourne, the freshwater wedge can extend up to $40 \mathrm{~km}$ offshore. Sand dune deposits along the coast can also be regionally important; for example, the Tomago Sandbeds, formed during a Pleistocene sea highstand, provides water security for the coastal city of Newcastle. 


\section{Groundwater: a critical resource}

\section{The first Australian use of water}

Aboriginal Australians have inhabited this land for millennia, navigating the changes in climate as it has cycled from wet to dry periods through at least 50 or 60 kyr. How has the longest continuous surviving human culture prevailed throughout much of the land, particularly when the interior was so arid? The answer may lie in three enduring strategies of traditional knowledge, oral instruction and stylised mapping.

Traditional knowledge of the location and nature of water supplies has accumulated by keen observation over thousands of years. Precise classification of water sources in terms of location, volume, quality and duration of supply provided a critical survival strategy and shaped daily life. Aboriginal languages distinguish various water sources: gnammas or rockholes holding temporary supplies after rain; intermittent claypan depressions; riverine waterholes; or soaks and perennial springs supplied by groundwater. The Karijini people of the West Canning Basin, for instance, have a concept of 'top' water and 'bottom' water, roughly corresponding with rain-fed and groundwater-fed features. Aboriginal terminology can also extend to differentiating between groundwater provinces. In the Jawoyn language (NT), maminga is water carbonated or high in lime, igilarrang is a similar 'light water' hosted in sandstone, and yiman wiyan is 'heavy water' hosted in basalt.
After rain in desert areas, Aboriginal groups could venture out to the country around the temporary water points, secure in the knowledge that they had a perennial source to which to retreat. Hence, permanent habitation of the desert was really only made possible by the more reliable groundwater supplies that acted as critical refuges. These regions were also refuges for the biota (Chapter 3) that provided the food supply for the Indigenous people. The sand dunes of Australian deserts can conceal an extensive palaeodrainage system representing buried remnants of Eocene rivers, and they are a good example of groundwater refuge. Many of these palaeovalleys are occupied now by salt lakes, which have fresh springs discharging around the edges. In places, caves and excavated wells in calcretes have also provided access to shallow groundwater. In the Simpson Desert (SA and NT), the Wongkamala and Wangkangurru people were able to survive by digging wells known as mikari. These are located in interdunal depressions, and are dug into gypcrete to depths of $4-6 \mathrm{~m}$ in a landscape where there are no surface clues as to the presence of groundwater. Geology has shaped tribal boundaries; in the Geraldton area, for instance, distinction is made between the 'rockhole' people of the inland fractured rock terrain, and the 'well' people of the Perth Basin.

Oral instruction, through storytelling and ceremonies, allows the knowledge base on water supplies to be passed on from generation to generation (Box 7.1). Such stories relate to the Dreaming, the time when the Ancestral Beings traversed the land, creating life and significant landscape features along the way. The Dreaming,

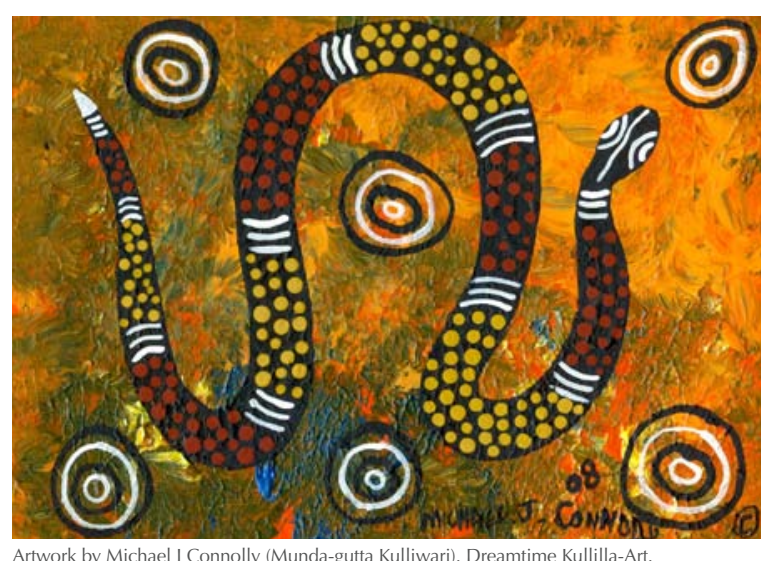

Artwork by Michael J Con
www.dreamtime.auz.net

The Rainbow Serpent is a highly significant cultural entity of the Dreaming, connecting many Aboriginal tribal groups across Australia and always associated with water. 


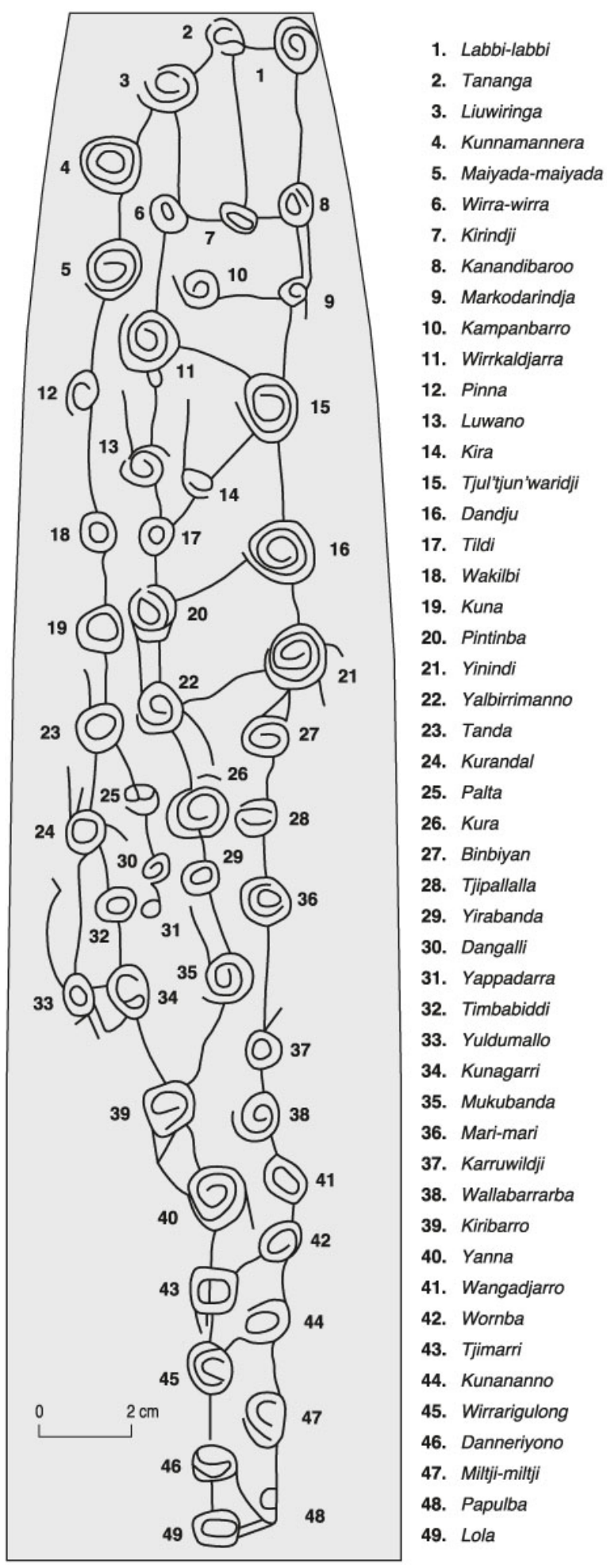

or Tjukurrpa in the Arrernte language around Alice Springs, also means 'to see and understand the law', emphasising the role of Dreaming stories in conveying traditional knowledge and cultural boundaries. The Rainbow Serpent is a highly significant cultural entity of the Dreaming, connecting many Aboriginal tribal groups across Australia and always associated with water. The Rainbow Serpent can journey across the sky, on land and underground. The water cycle is neatly encapsulated in this powerful and not entirely benign creator ancestor. Water, as represented by this mythological serpent, is the dimension that connects the Earth and sky, with groundwater the underground home and tracks of these beings. In the Wardaman language (NT), barlba is the term used to describe these underground travels and pathways to the surface. Groundwater-fed springs are so entwined with the Rainbow Serpent that, if one dries up, this is attributed to the Rainbow Serpent being disturbed and moving on.

Storytelling also takes on an important spatial dimension. For example, the journeys of Dreaming ancestors such as the Rainbow Serpent may be recounted as a strict sequence of short songs, each relating to a particular place. An oral map of ancestral travels is built up, allowing Aboriginal people to navigate between strategic water supplies using the paths defined in this way. Such 'songlines' or 'dreaming tracks' can create a network many thousands of kilometres long and connecting

Figure 7.3: A stylised map of the regional water resources of the Bindibu (Pintupi) people of the Great Sandy Desert, Western Australia, carved into the back of a spear thrower. (Source: drawn by Bayly (1999) from a photograph of Thomson (1962)) many tribal groups. Geology can play a role-for example, in the Perth Basin, the songlines tend to follow the sedimentary geological features, which give rise to springs and soaks.

Stylised mapping can be used to supplement the oral tradition of communicating water knowledge. These maps were portrayed in many forms, including decorated weapons or domestic implements, rock engravings, body paintings or sand drawings. Concentric circles typically represent the water supply, and these are connected with lines, perhaps in the appropriate compass direction, but not to scale in terms of distance. Most importantly, these maps are placed into context by detailed narrative, with each water source named and described. This allowed the transfer of detailed water resource knowledge from generation to generation. The anthropologist Donald Thomson gives an account of how this was managed by the Bindibu of the Great Sandy Desert. Thomson suddenly realised that, through such oral instruction, a carved spear thrower (Figure 7.3) was in fact a highly conventionalised map of the regional water resources.

\section{British colonies and pastoral expansion}

The early coastal fingerholds of British settlement struggled to secure a perennial water supply in a land very different from the homeland (see Did you know? 7.1). Fortunately, sand dunes can contain fresh groundwater lenses, so this was a ready supply for many coastal settlements. Also, groundwater discharge to wetlands and streams allowed water supply to persist during dry times. 
Hydrogeology and groundwater processes can be seen embedded in certain Dreaming stories, reflecting Aboriginal affinity with the Australian landscape. Here are two examples from very different geological settings.

The first is set in the Mt Gambier volcanic complex and Australian Geopark (SA):

Craitbul, the giant ancestor of the Boandik people, and his family had only one tool, a wooden digging stick, and their bare hands to dig out underground tubers. This was their daily food, which they cooked in an earth oven. They happily established their first camps at Mt Muirhead and Mt Schank until the bird spirit Bullin warned them of the evil spirit Tennateona. They fled to safer refuge at Mt Gambier where they again dug their earth oven. One day, water bubbled up into the bottom of the oven and put out the fire. They dug other ovens, but each time the water rose and extinguished the fire. This occurred four times. Disgruntled, Craitbul and his family finally settled in a cave on the side of a nearby peak. (Roberts \& Mountford, 1979)

These volcanoes are about $4.5 \mathrm{ka}$; the youngest in mainland Australia. The eruptions would have been a compelling experience for the Boandik people. The dry crater floor of Mt Schank is above the regional water-table. In contrast, there are four groundwater-fed volcanic craters at Mt Gambier: Valley Lake, Blue Lake, Browne's Lake and Leg of Mutton Lake. An interesting feature of the Mt Gambier volcanism is the occurrence of
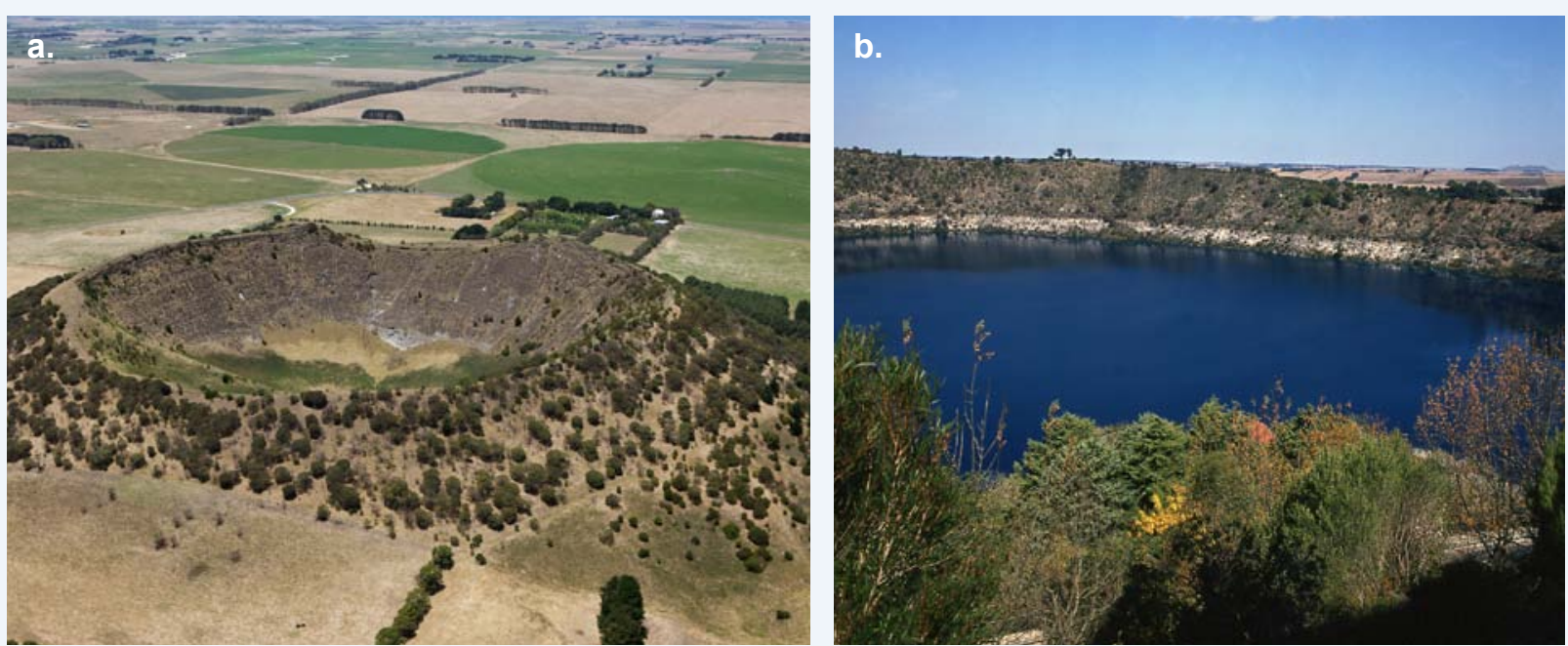

remnant blowholes caused by steam discharge from superheated groundwater, which would fit with the steam hissing as the oven fire was put out in the story.

The second example is a Wardaman Rainbow Serpent creation story for the Flora River, about $135 \mathrm{~km}$ southwest of Katherine (NT):

The black-headed python Walujapi created the Bulkbulkbaya spring in the Flora River by thrusting a digging stick into the ground. Walujapi pushed the digging stick through until it reached the spring water near Mataranka and the water flowed back, creating Bulkbulkbaya. (Cooper \& Jackson, 2008)

Modern hydrogeological mapping has confirmed that baseflow in the Flora River is from the Tindall Limestone Aquifer, with regional groundwater flow in a westerly direction from the Mataranka area.

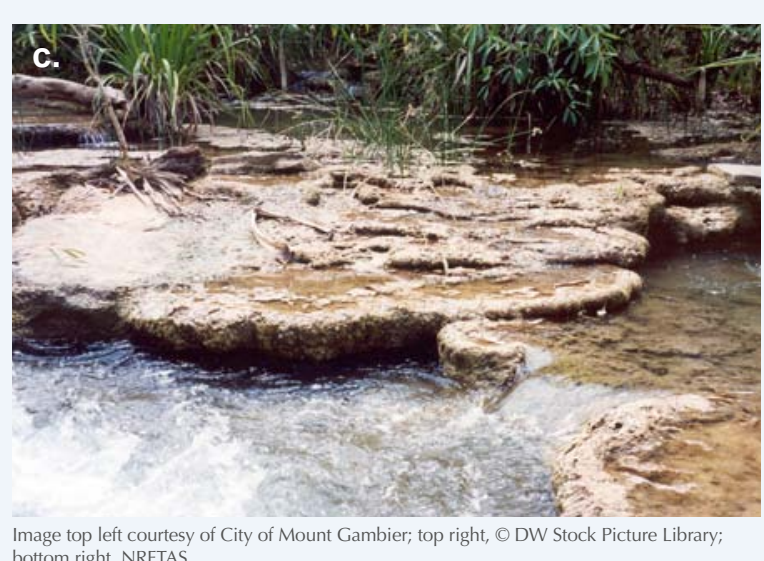

bottom right, NRETA

Figure B7.1: (a) Mt Schank, South Australia, is around $4.5 \mathrm{ka}$ the dry crater floor sits above the water-table. (b) The spectacular Blue Lake near the city of Mt Gambier in South Australia. It is one of the groundwater-fed volcanic crater lakes mentioned in the Craitbul Dreaming story of the Boandik people. (c) Tufa dams on the Flora River, Northern Territory. These are formed during the dry season when river flow is mostly groundwater from springs discharging upstream. The water is saturated with $\mathrm{CaCO}_{3}$ that precipitates with evaporation to form the dams. Local Aboriginal Dreaming stories acknowledge the provenance of the groundwater baseflow. 


\section{Did know?}

\section{1: Groundwater and early} European settlement

- Sydney's water supply for the first 40 years, the iconic but now buried Tank Stream, was fed from springs near what is now King and Spring Streets. The Tank Stream was replaced as a water supply by Busby's Bore, which was actually a tunnel to gravity feed water from the Lachlan Swamps (now Centennial Park); the swamps were fed by groundwater from the Botany Sands aquifer.

- The initial attempt to settle the Port Phillip area was not at Melbourne, but at Sullivan's Bay, $60 \mathrm{~km}$ to the south. A shallow well, constructed from six wooden barrels sunk into the sand, was the only water source for the 467 convicts, marines and free settlers.

- Captain James Stirling reported on the prospects in 1827 of founding a city on the Swan River: 'supply of fresh water from springs and lagoons is abundant ... it may be confidently assumed that water is plentiful all over this territory'. This may have been an optimistic assessment, but Perth's early groundwater supply is still commemorated by Spring Street in the city.

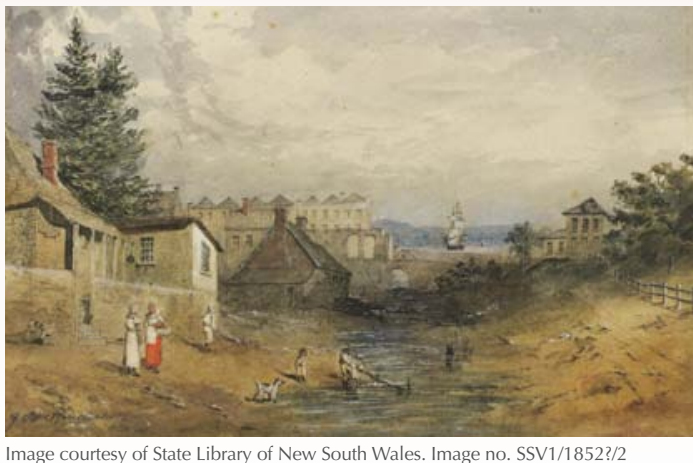

Old Tank Stream Sydney, 1852; watercolour by John Black Henderson.
European 'taming' of the land fanned inland from these coastal enclaves. This was encouraged by reports of favourable grazing lands in the journals of early explorers and surveyors who finally managed to cross the Great Divide west of Sydney (Chapter 5). Pastoralists and farmers followed the rivers, but utilisation of the land away from permanent watercourses involved the sinking of wells. Some of the first New South Wales government expenditure on rural water conservation works was the allocation of $£ 2900$ (around $\$ 300 \mathrm{~K}$ today) in 1866 to sink wells along a stock route from the Darling to the Lachlan and Warrego rivers.

Grazing in many areas is totally dependent on the ability to obtain groundwater. Throughout the extensive pastoral country of Western Australia's Precambrian bedrock, limited supplies of water can be obtained from the overlying surficial deposits, or the weathered bedrock itself. Such is the widespread occurrence of groundwater that station paddocks are laid out in a grid pattern with regular spacing of water points at paddock corners. In this way, European order could prevail over an ancient Australian landscape. The ubiquitous windmill, or more correctly windpump, was transformed from its North American origins in 1854 into a symbol of Australia.

\section{The Canning Stock Route}

The vast ranges and plains of Australia ensured, as was the case in the Americas, that 'cowboys' played a role in the development of the country. One theme of the bush is that of the drover, wandering from one waterhole to the next with his 'mob' of cattle.
By the turn of the 19th century, stock routes were needed to drive the herds of cattle from vast outback stations to markets at the coast. These stock routes became colloquially known as the 'long paddock' (long field). One of the most famous was the Canning Stock Route in Western Australia.

Established in 1910 as a $1850 \mathrm{~km}$-long route to drive cattle from Halls Creek in the Kimberley to Wiluna in the south, the Canning Stock Route traverses four deserts and is the longest historic example of its kind in the world. Of paramount importance to Alfred Canning's initial 1906 expedition was to locate water supplies at regular intervals along the route. The desert terrain is mostly underlain by Permian to Jurassic sandstones, and the water-table is generally deep. The surveyed route utilises Cenozoic palaeovalley aquifers in which the groundwater is shallow, and where groundwater discharges to salt lakes (Figure 7.4). Good groundwater supplies could also be obtained from surficial calcretes.

Canning did not use geological knowledge to choose the route. Instead, he captured local desert people and forced them to lead him to traditional watering points. Of the 54 water sources staged along the route, 48 are constructed wells of which 37 are on or near Aboriginal jumu (soakwaters) or jila (springs). The crude and illegitimate methods Canning used to find water were the subject of a Royal Commission. The enmity between Aboriginal inhabitants and the Europeans was reflected in the fatal spearing in 1911 of three drovers at Well 37, and subsequent reprisal shootings. By 1917, nearly half of the wells had 
been damaged or destroyed and, by 1931, only eight mobs of cattle had used the route. Although the wells were reconditioned, changing markets and a shipping alternative eventually resulted in the demise of the stock route, with the last cattle run in 1959.

Today, the route is busier than it has ever been, used not by drovers but by $4 \mathrm{WD}$ travellers keen to experience the landscape's beauty and remoteness and learn more of the art and culture of the traditional Aboriginal owners.

\section{The Great Artesian Basin: Australia's largest groundwater resource}

The Great Artesian Basin is Australia's largest groundwater resource and underlies one-fifth of the nation's land surface (Figures 7.1 and 7.5). European pastoral settlement of the Australian interior would not have been complete without this water. With pumping equipment being expensive and difficult to maintain, the tapping of free-flowing groundwater in the basin would have been manna from heaven for the early pastoralists (Figure 7.6). The first flowing bore was unintentionally drilled in 1878 when a shallow well was reconditioned and deepened to $53 \mathrm{~m}$, on remote Kallara station, southwest of Bourke (NSW). This bore was adjacent to the Wee Wattah mud springs, prompting the drilling of similar shallow bores with small flows near other springs across the basin.

A number of scientists independently predicted the potential for artesian bores in different parts of the basin. In 1879, pioneering South Australian

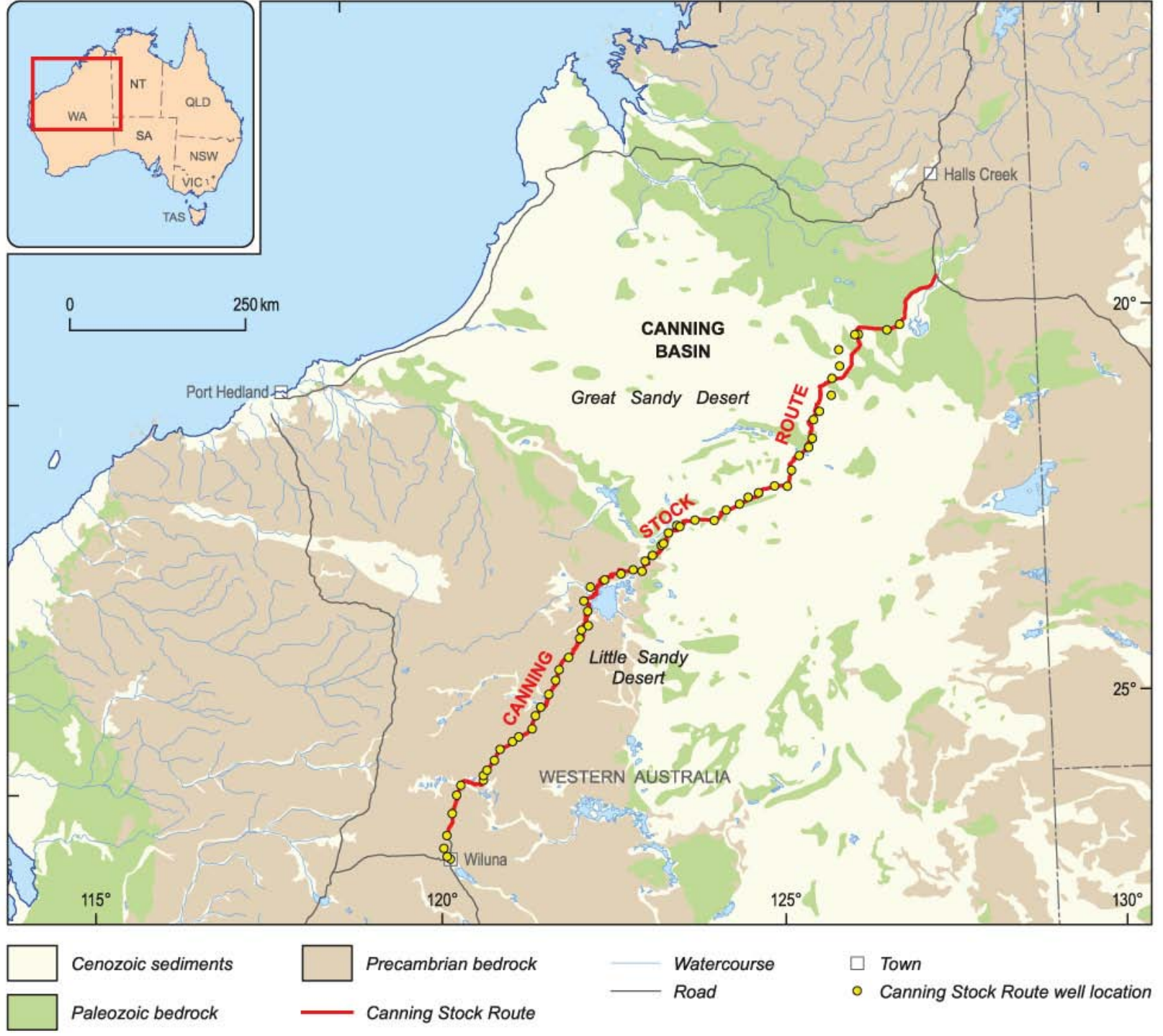

geologist Ralph Tate inferred this from the mound springs near Lake Eyre. In 1880, the first New South Wales Government Geologist, Charles Wilkinson, used the Kallara flowing bore to come to the same conclusion for the vast surrounding plains. His counterpart in Queensland, R Logan Jack, also made favourable reports for artesian conditions in the western interior of that state.
Figure 7.4: The Canning Stock Route between Halls Creek and Wiluna, Western Australia. The water points along the route took advantage of shallow groundwater resources hosted in calcretes and palaeochannel alluvials. 
Incidentally, on the other side of the continent, Western Australian Government Geologist ET Hardman had pronounced the artesian prospects in the Perth Basin as poor, owing to the lack of upturned sediments, although he was later proved wrong. The very first known artesian bore in Australia, albeit brackish, was a $51 \mathrm{~m}$-deep coal exploration hole in the Perth Basin in 1871 (See Did you know? 7.2).

The advent of the Canadian pole-tool technology suddenly brought drilling capability to depths exceeding $300 \mathrm{~m}$. Application resulted in spectacular successes in 1887 with the Thurralgoona bore near Cunnamulla (Qld) and the Kerribree bore near Bourke (NSW). By 1899, a total of 524 flowing artesian bores had been drilled in Queensland alone. On the eve of the 20th century and Australian federation, artesian water had become part of the Australian psyche, with the belief that free-flowing groundwater could be obtained if only one drilled deep enough. An assured water supply distributed by thousands of kilometres of bore drains brought manifest change to the people and ecology across the vast inland plains, none more so than the Great Artesian Basin.

The Great Artesian Basin is an exemplar for continental-scale confined groundwater systems, being one of the world's largest. It contains sandstone aquifers spanning across the Triassic, Jurassic and Cretaceous with combined thicknesses

Figure 7.5: Map of the Great Artesian Basin and localities. Also shown is the extent of the groundwater flow paths, the springs and the spring groups. (Source: Radke et al., 2000)

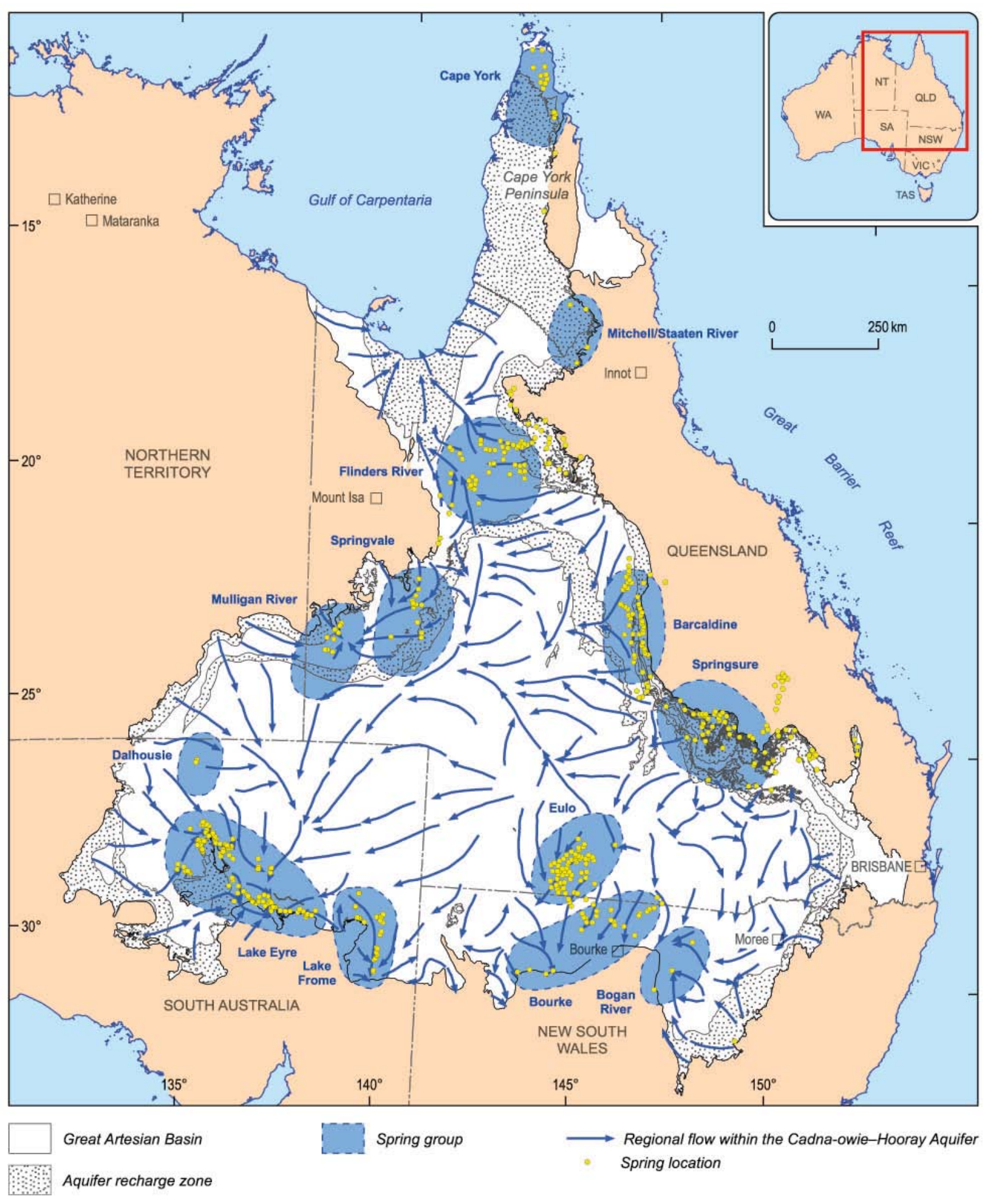


between $100 \mathrm{~m}$ and more than $3000 \mathrm{~m}$. The Great Artesian Basin is also an aggregate of sedimentary basins, most notably the Eromanga, Surat and Carpentaria (Figure 2.8).

Potentiometric contours are lines of equal hydraulic head, and these, together with hydrochemistry, reveal that the Great Artesian Basin aquifers are recharged by rainfall and river leakage through exposed intake beds along the basin margins, particularly to the east (Figure 7.5). The relatively high topographic elevation of these recharge beds is the key hydraulic driver of the basin. Conditions become pressurised down-gradient in the basin, where the aquifers become confined by overlying marine siltstones and mudstones. Isotope analyses $\left({ }^{36} \mathrm{Cl}\right.$ and $\left.{ }^{14} \mathrm{C}\right)$ show a progression in groundwater age, some exceeding $2 \mathrm{Ma}$ in the southwest part of the basin. Groundwater velocities have been estimated at $1-5 \mathrm{~m} /$ year. These rates may appear to be slow, but over time they translate to potential flowpaths exceeding $2000 \mathrm{~km}$ in $2 \mathrm{Myr}$. Groundwater from the commonly exploited confined aquifers is typically a sodium-bicarbonate type with salinities of $500-1000 \mathrm{mg} / \mathrm{L}$.

Groundwater storage in the basin is estimated to be about $65000 \mathrm{~km}^{3}$. The basin, however, is not managed in terms of extraction volumes but in terms of aquifer pressure. More than 4700 flowing artesian bores have been drilled in the basin since the 1870s. Basin outflow peaked at more than $2 \mathrm{GL} /$ day in 1918, with aquifer pressures declining ever since. Such a decline has meant that groundwater flow in many natural springs and artesian bores has decreased or even ceased. Also, water use has been inefficient due to uncontrolled flows and the leaky open-earth drains commonly used to distribute water (Figure 7.6). Secondary problems have been caused, such as salinisation,

\section{Song of the Artesian Water}

As the drill is plugging downward at a thousand feet of level, If the Lord won't send us water, oh, we'll get it from the devil; Yes, we'll get it from the devil deeper down.

But it's hark! the whistle's blowing with a wild, exultant blast, And the boys are madly cheering, for they've struck the flow at last; And it's rushing up the tubing from four thousand feet below, Till it spouts above the casing in a million-gallon flow.

And it's down, deeper down -

Oh, it comes from deeper down;

It is flowing, ever flowing, in a free, unstinted measure

From the silent hidden places where the old earth hides her treasure -

Where the old earth hides her treasures deeper down.

\section{AB Paterson (1896)}

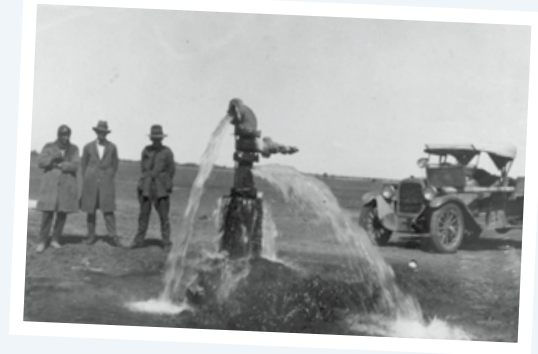$$
\text { Image courtesy of John Oxley Library, State Library of Queensland, Neg: } 50456
$$

\section{Did know?}

\section{2: First attempt}

Drilling in the Great Artesian Basin was not the first attempt to find 'artesian' water in Australia. In 1850, the New South Wales Governor established the Artesian Well Board 'for the purpose of considering and reporting as to the best means of conducting an undertaking for endeavouring to obtain an abundant supply of pure water for the City of Sydney, by boring on the Artesian principle within the walls of Darlinghurst Gaol'.

The gaol was selected because its elevated position allowed water to be distributed by gravity, and hard-labour convicts could be used on a treadmill to power the boring plant. The chairman of the gaol board, geologist Reverend WB Clarke was not overly confident of the venture, estimating that it would take three years to bore to $500 \mathrm{ft}(150 \mathrm{~m})$. His pessimism proved justified, as the hole was abandoned at $75 \mathrm{ft}$, not because of any geological reason, but because (unpaid) convicts sabotaged the equipment.

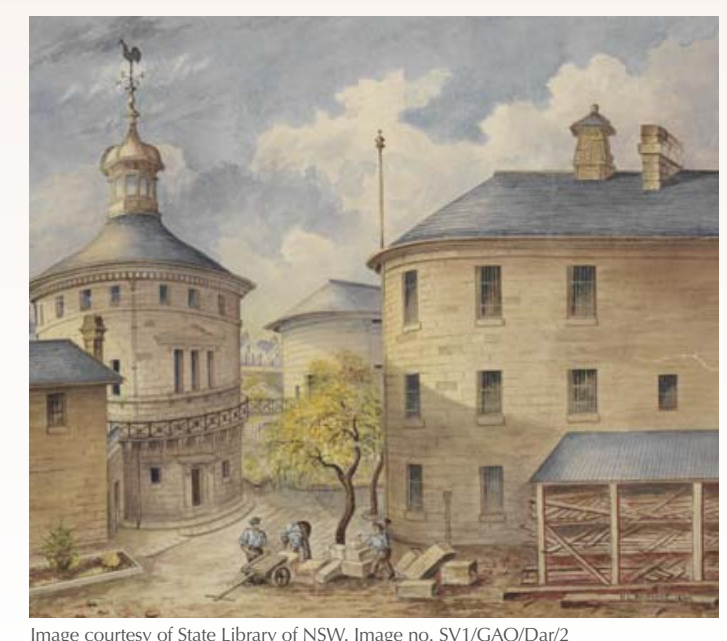

Watercolour of Darlinghurst Gaol by HL Bertrand (1891). 


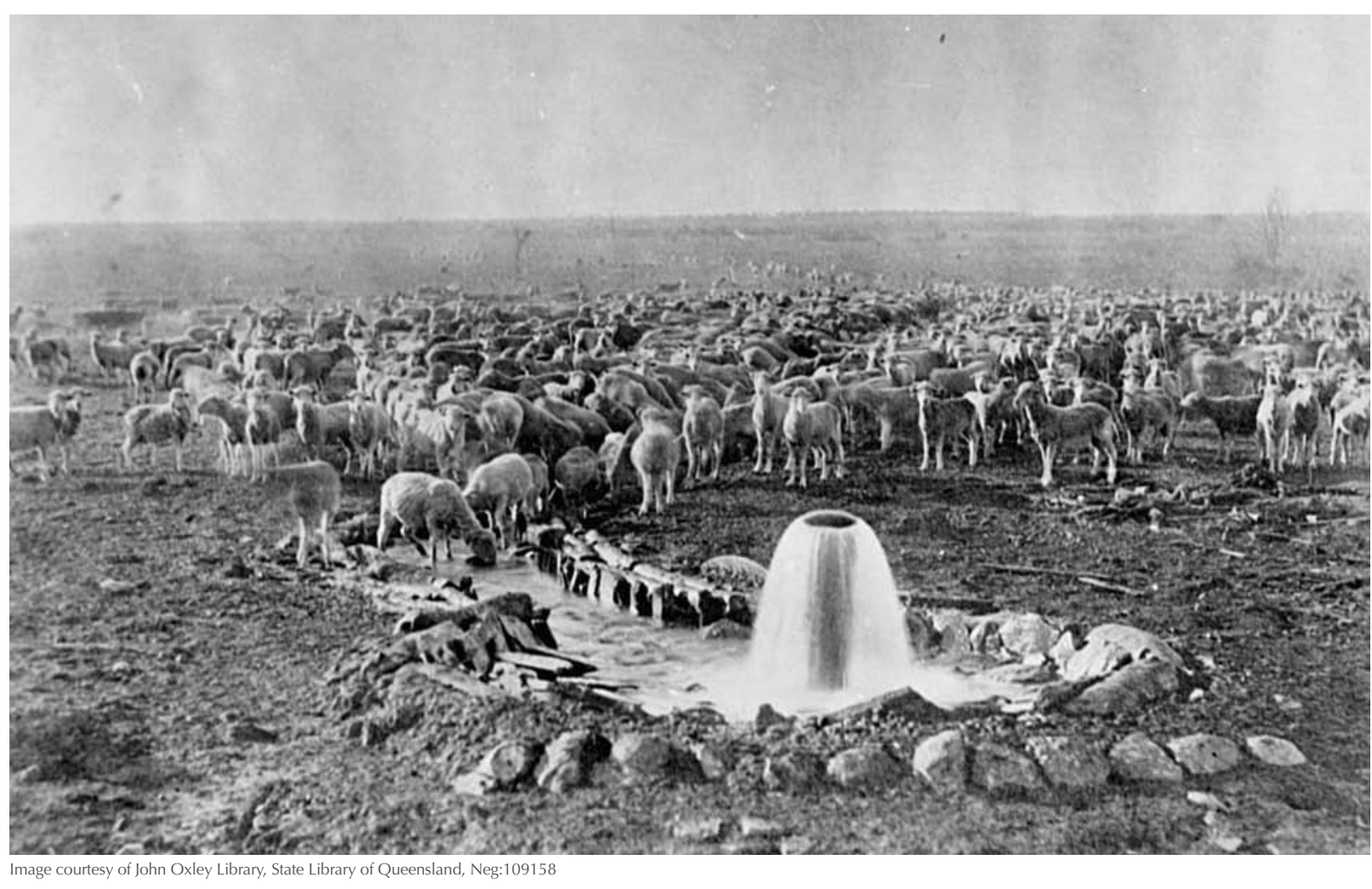

Figure 7.6: Historical photograph of a flowing artesian bore in the Queensland part of the Great Artesian

Basin. (Source: John Oxley Library, Great Artesian Basin Coordinating Committee) erosion and the spread of weeds and feral pests. These problems are being addressed in part by a basin-wide program of capping or reconditioning of bores and replacement of open drains with reticulated pipelines.

The decline in aquifer pressures that followed the initial exploitation of the Great Artesian Basin stirred scientific enquiry into its groundwater origins. Even before 1900, it was widely recognised that groundwater had a meteoric origin —namely, sourced by recharge from rainfall. The main protagonist for this majority view for the Great Artesian Basin was the New South Wales Government Geologist, Edward Pittman. However, a protracted scientific debate was sparked when JW Gregory, Professor of Geology at Melbourne University, advocated an alternative plutonic origin-groundwater sourced from the cooling of deep-seated igneous rocks. His views were first revealed in a lecture in 1901 and later expanded upon in his book The dead heart of Australia (1906), following his travels to the mound springs near Lake Eyre.

One of the many lines of evidence used by Pittman for a meteoric source came from a 19th century equivalent of a catchment water balance. Government Astronomer HC Russell estimated that less than $1.5 \%$ of the rain falling in the upper Darling River catchment flowed past Bourke, and concluded that a significant proportion of rainfall neither evaporated nor became surface drainage. The civil engineer TE Rawlinson had appealed for an enquiry in 1878 :

into the cause of the disappearance of the vast bodies of river water which collect on the inner water-shed of the coast ranges of Australia

and considered that the interior of Australia would

ultimately be proved to be the storage reservoir where are conserved the rain and river waters which other theories fail to account for.

Pittman also cited overseas geologists, including TC Chamberlin of the University of Chicago, who had developed a list of the necessary geological prerequisites for artesian conditions. These included surface exposure of permeable intake beds, inclined strata, and both underlying and overlying impervious beds, features that were mirrored in the emerging understanding of Great Artesian Basin geology. 
Gregory, although recognising the existence of meteoric water, asserted that the Great Artesian Basin waters were mostly ancient, plutonic, deep-seated crustal water. He claimed that relatively high temperatures and enrichment of sodium $(\mathrm{Na})$, potassium $(\mathrm{K})$ and zinc $(\mathrm{Zn})$ in certain artesian bores were characteristic of such a source. The corrosion of bore casing he thought was due to elevated concentrations of boric acid, which was claimed as another indicator of plutonism. This interpretation was refuted by Pittman, who demonstrated that high $\mathrm{Zn}$ concentrations could simply be attributed to corrosion of the Zn-galvanised bore casing pipes.

Although Pittman and Gregory had an amiable professional relationship, this did not prevent them from engaging in vigorous public debate. It was evident that the whole matter required careful investigation and review, and to this end the New South Wales Government invited other states to form a consultative board and the first, of what ultimately was to be five, Interstate Conferences on Artesian Water. The official statement from this 1912 conference in Sydney concluded that the artesian water 'is almost, if not entirely, derived from rainfall' (Figure 7.7).

\section{Water and mining: the thirsty work of industry}

The year 1851 marked the transformation of a nation. Gold was found by a waterhole near Bathurst, about $200 \mathrm{~km}$ inland from Sydney, quickly followed by Victorian discoveries in Ballarat and Bendigo. Over the next two decades, the population of Australia increased four-fold

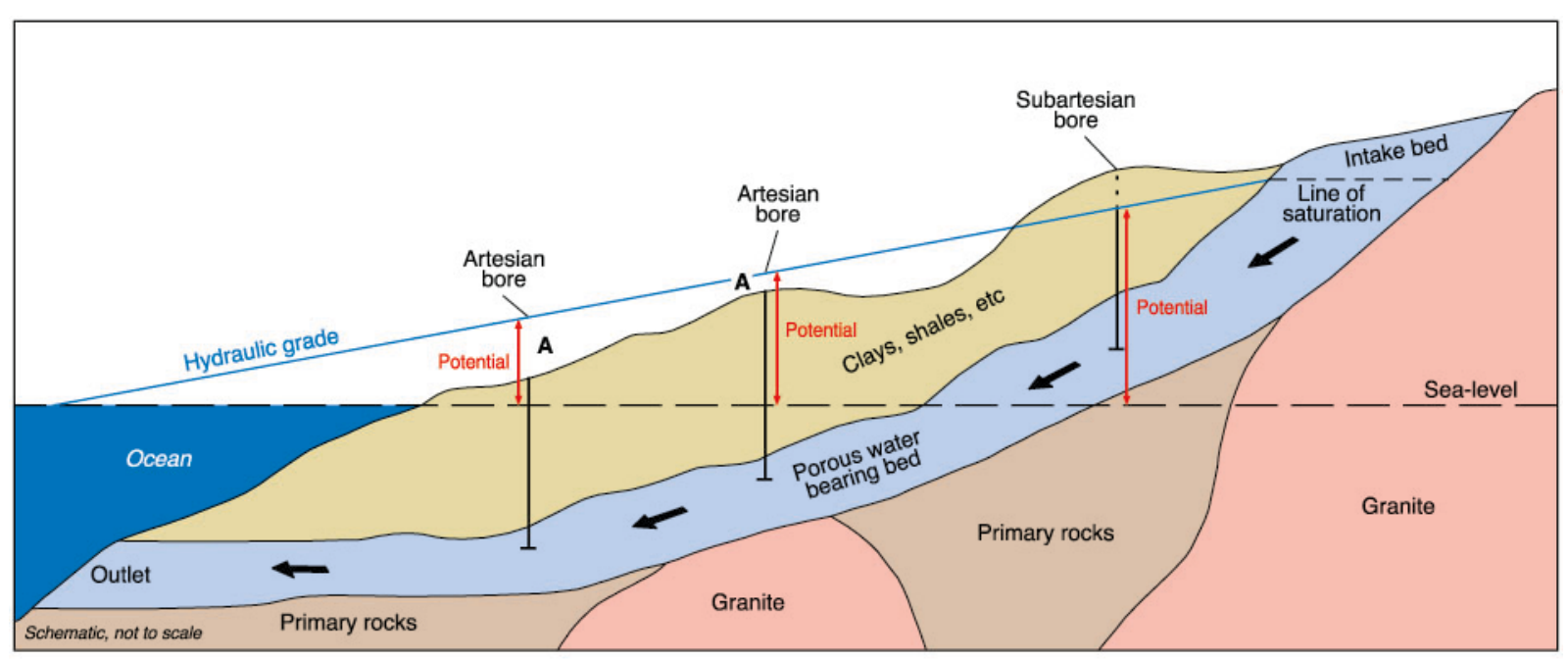

(Chapters 1 and 8). Reported finds across Australia were inevitably followed by a rush, involving thousands of ill-prepared would-be miners. The location of hastily erected inland settlements could not necessarily be chosen by the presence of permanent water. Some fields had to be evacuated by the authorities when water supplies ran out, and many miners died of thirst and waterborne disease.

The Eastern Goldfields (WA), discovered in the 1890s (Chapter 8), present a classic study of the trials and tribulations of securing water. According to the young Herbert Hoover (later United States president), the area around Leonora was 'red dust, black flies and white heat'. Reliable sources of local water were difficult to secure. Wood-fired condensers were initially used to desalinate the local groundwater, but these were responsible for deforesting the surrounding region. The distilled water was also outrageously expensive, with the price for less than 15 litres being the equivalent of an unskilled worker's weekly wage. The government even wasted a large sum of money
Figure 7.7: Redrawn historical depiction of an artesian basin with an outlet to the ocean, based on the Artesian Water Report of the Second Interstate Conference on Artesian Water, Brisbane, 1914. By the start of the 20th century, the geological and hydrological principles driving artesian groundwater condition in confined sedimentary aquifers had been firmly established. (Source: modified from Faggion, 1995) 


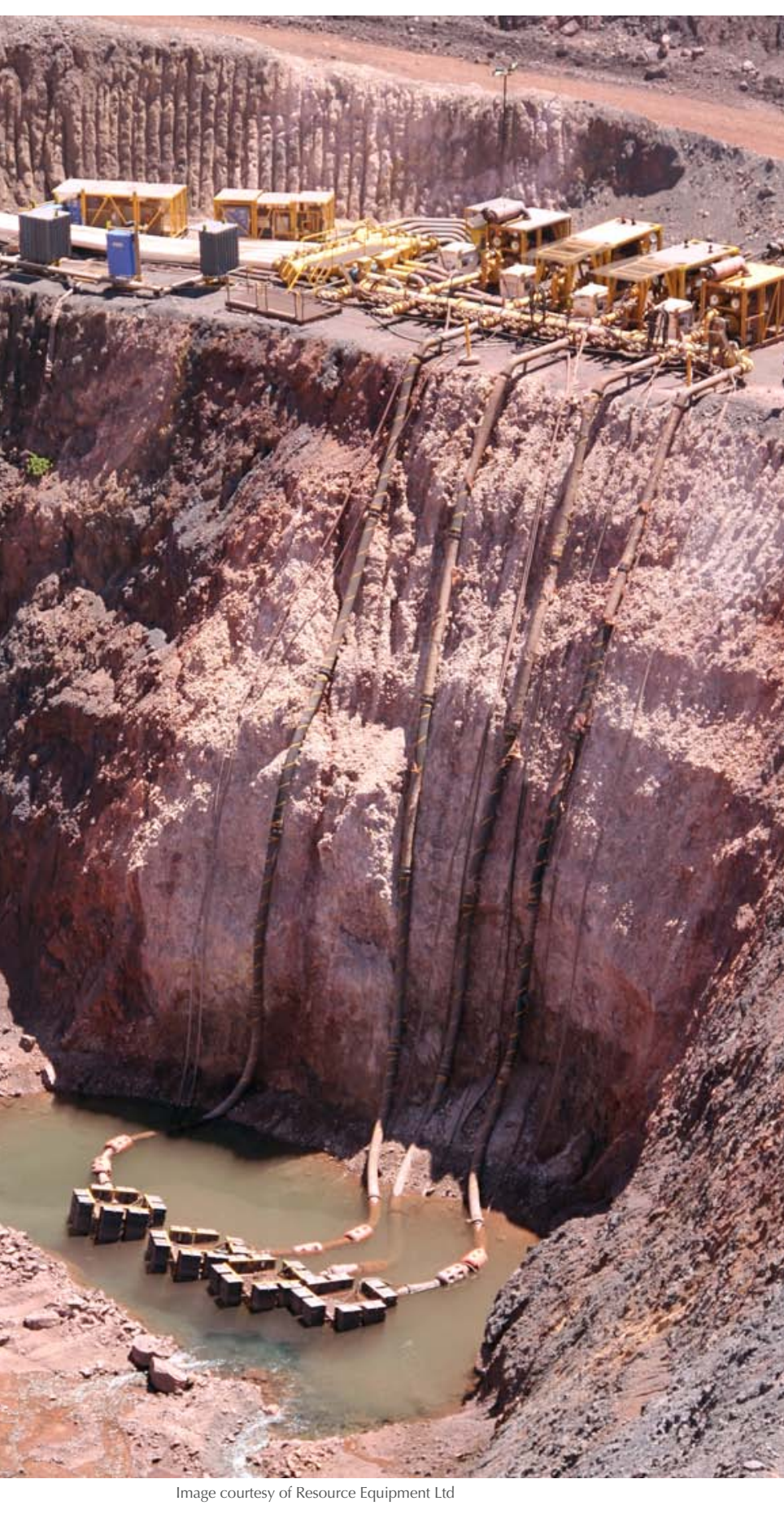

Figure 7.8: Mines that enter below the water-table need to be dewatered. Pumping water is energy intensive, and the water needs to be disposed of in an environmentally sustainable way. in drilling to $900 \mathrm{~m}$ for 'artesian water' in solid granite, ignoring the Government Geologist's adverse advice. It was only with the construction of engineer CY O'Connor's epic $600 \mathrm{~km}$ pipeline from Mundaring Weir near Perth that a viable water supply was finally delivered to the goldfields in 1903. In 1904, the daily water consumption on the goldfields was more than $5.5 \mathrm{M}$ litres. Eighty years later, there was a resurgence of interest in the saline groundwater, with the introduction of carbon-in-pulp gold processing that could utilise the resource (Chapter 8). Drilling discovered a network of palaeochannels in basal Eocene sands that proved to be excellent aquifers. Bores typically spaced $1 \mathrm{~km}$ apart along the palaeochannels now access the saline groundwater for ore processing.

Some goldfields encountered the opposite problem of too much (ground) water. The Victorian deep-lead gold $(\mathrm{Au})$ deposits are hosted in Cenozoic alluvials, commonly buried by basalt flows, which are also important aquifers. Mine dewatering proved to be a major challenge. For example, it was reported that in its heyday 170 horse-drawn winches (called whims) were used to dewater the gravel-hosted alluvial Au at the Majorca field in Victoria.

Mine dewatering has continued to be a significant issue across Australia. Since the 1990s, most of the major iron ore mines in the Pilbara have extended their operations to depths below the water-table (Figure 7.8). Mining is on a truly gigantic scale in the Pilbara. Some $400 \mathrm{Mt}$ of iron ore are exported annually (Chapter 9), and this involves pumping millions of tonnes of groundwater to allow the ore to be mined from open pits. Total allocation for mining extraction in the region is $268 \mathrm{GL} /$ year, of which about half is for dewatering. Much of the groundwater is hosted in Miocene-aged channel-iron deposits, which are porous and permeable pisolitic iron accumulations in the bottom of valleys in the Hamersley Range. Today they form major freshwater aquifers, recharged periodically by rapid runoff caused by cyclonic rain. The mining involves removing the whole aquifer, and water pumped to dewater the pits is either discharged to normally dry creek beds, creating perennial flow and a new ecosystem that will collapse when dewatering ceases, or is reinjected in the aquifer further downstream.

Groundwater is also a major consideration in mining the Chichester Range deposits of Marra Mamba Iron Formation, adjacent to the Fortescue Marsh in the central Pilbara, where the underlying groundwater is saline. This presents a challenge in dealing both with fresh groundwater and with hypersaline groundwater, which cannot be discharged to the surface or used for processing. At one mine, $24 \mathrm{GL} /$ year needs to be pumped, with much of this water reinjected into the aquifer.

In the East Pilbara, on the edge of the Great Sandy Desert, $16 \mathrm{GL} /$ year of fresh groundwater is discharged to the Oakover River from the Woodie Woodie manganese $(\mathrm{Mn})$ mine. Proposals to use the dewatering to supply the water-deficient coastal towns of Karratha and Port Hedland have been considered, but the distances of hundreds of kilometres, and the transient nature of dewatering, militate against finding a use for this mining by-product. 


\section{Food for the nation and beyond: Australian irrigation}

Making the desert bloom was a deeply held yearning for European settlers to Australia, and it would only be a matter of time before the free-flowing Great Artesian Basin bores were investigated for irrigation development. In the 1890s, the New South Wales Government subdivided about 700 acres (280 ha) around the Pera Bore near Bourke for this purpose. However, the Great Artesian Basin groundwater is enriched in $\mathrm{Na}$ relative to calcuim (Ca) and magnesium $(\mathrm{Mg})$, even though overall salinity is low. This meant that it was not long before difficulties were experienced, with local soil structure degrading after irrigation. It took 14 years until the irrigation scheme finally had to be abandoned.

Most irrigation schemes using groundwater in Australia were established following World War II. Governments actively promoted the development of groundwater resources by providing technical advice, drilling rigs and financial assistance to farmers. By 1950, the New South Wales Government was operating 20 drill rigs throughout the state. Attention was drawn to the inland alluvial deposits of the Murray-Darling drainage system, with early drilling investigations focusing on the Lachlan and Namoi valleys. Shallow groundwater had been used for stock and domestic purposes, but, with the discovery of deeper and more productive aquifers, graziers became irrigators.

This groundwater development was replicated to varying degrees in the other states. Major irrigation of sugar cane and horticultural crops now occurs

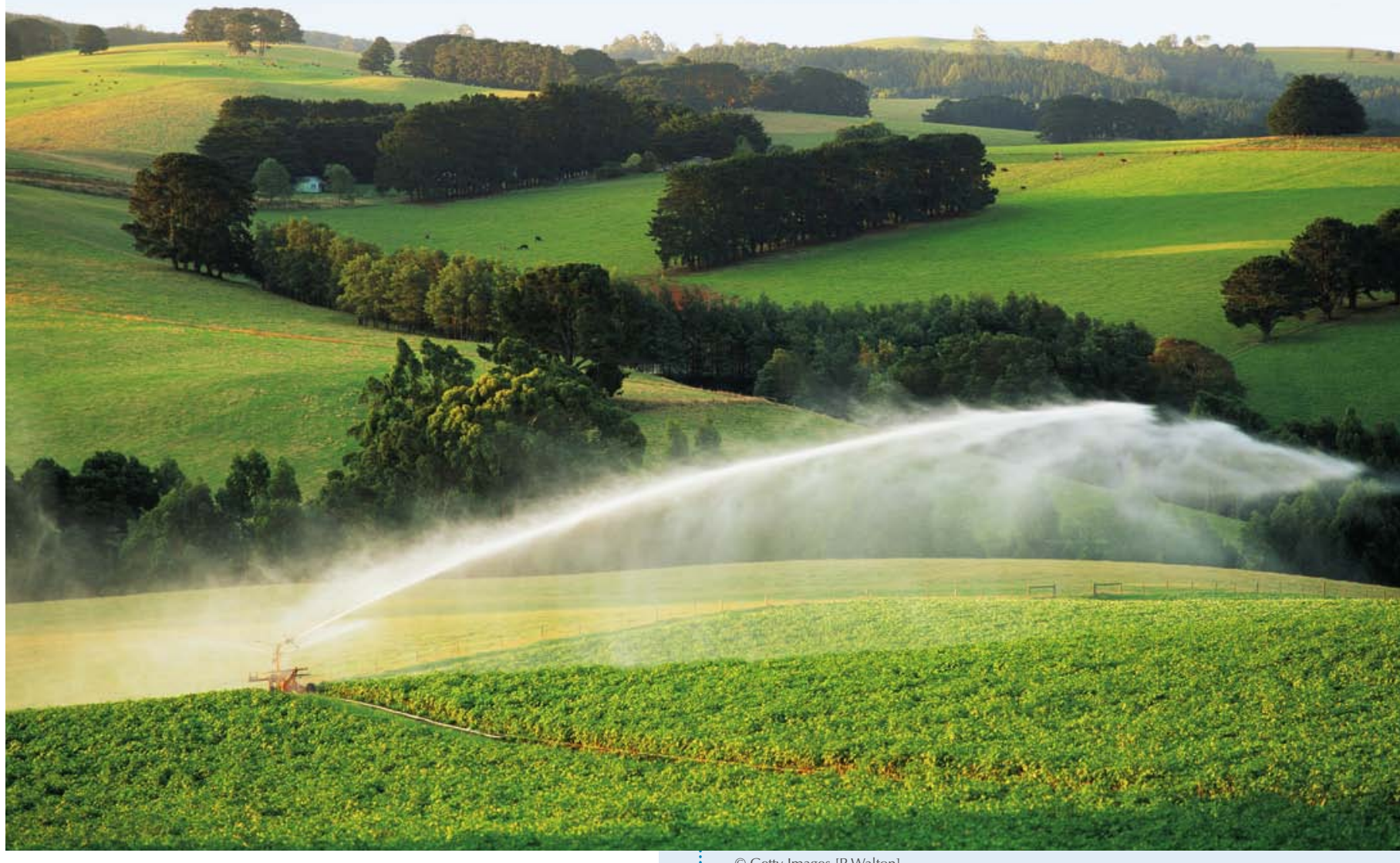

along the Queensland coast, such as in the Burdekin and Bundaberg districts, which use groundwater accessed from alluvial and deltaic aquifers. Near Alice Springs in central Australia, early-season table grapes are grown using groundwater from the Cenozoic Ti Tree Basin. Alluvial aquifers of the Gascoyne River near Carnarvon are used to irrigate fruit and vegetable crops for the Perth market, $1000 \mathrm{~km}$ to the south. In South Australia, groundwater is turned into wine in grape-growing regions such as McLaren Vale, Langhorne Creek and the Barossa Valley (Chapter 5). 


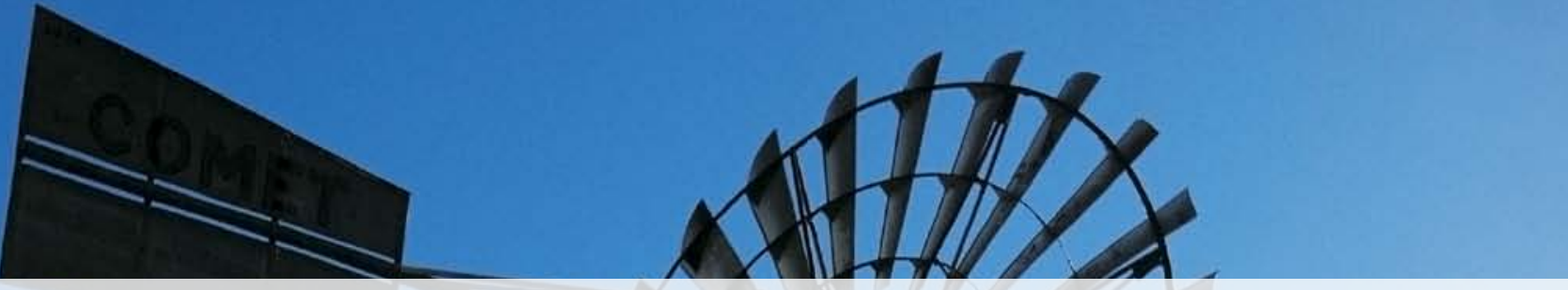

WHAT ARE GROUNDWATER MANAGEMENT UNITS (GMUs)?

\section{(BOX 7.2}
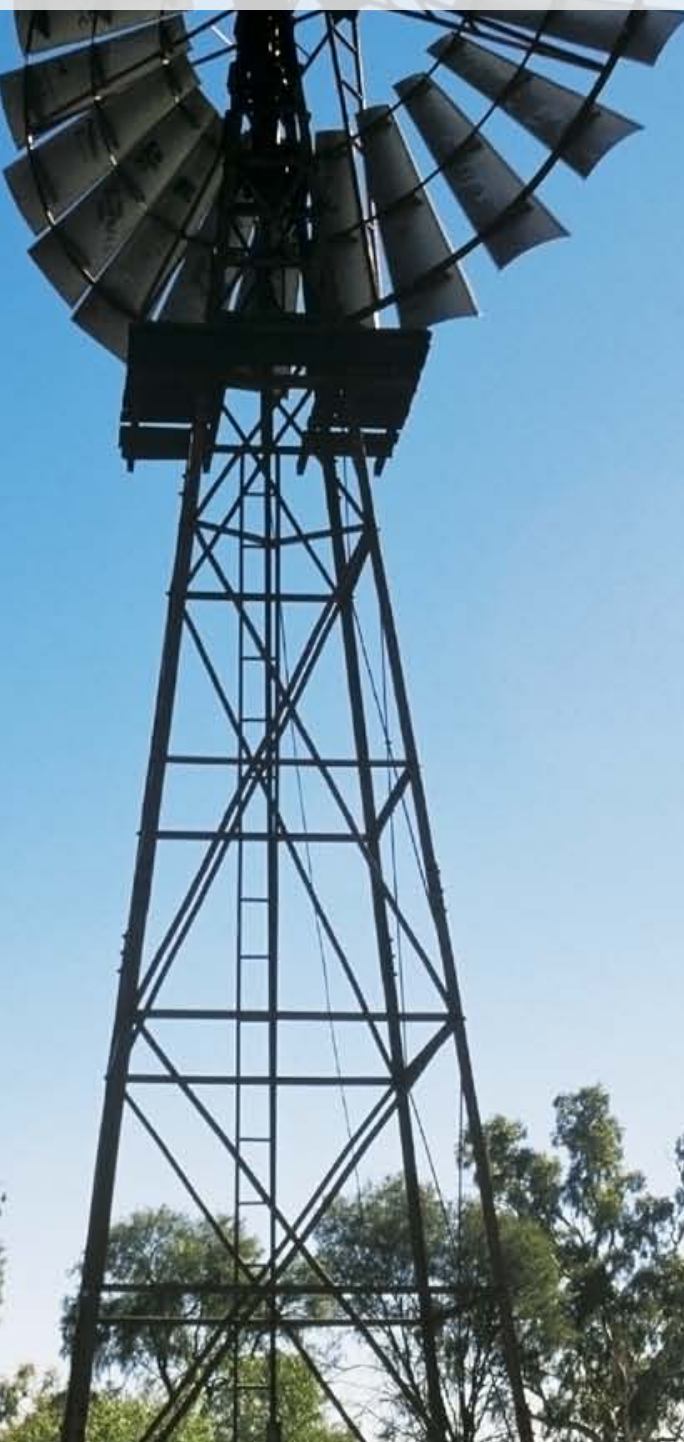

In Australia, groundwater resources and their management are the responsibility of the states and territories. From the early 1900s, the main groundwater management focus was on the regulation of artesian water, because it was realised very early on that uncontrolled flows would lead to pressure reduction and essentially resource depletion (Figure B7.2). The Interstate Conferences on Artesian Water, held between 1912 and 1924, were the first national attempts to discuss groundwater management. Conference proceedings also collated the first bore databases, albeit only for deep 'artesian' bores.

From the 1950s, a boom in groundwater use, mainly for irrigation, was followed by concerns that certain aquifers were becoming stressed, as indicated by falling groundwater levels. This prompted state governments to define management boundaries around areas of interest so that groundwater use could be controlled. For example, in Western Australia, the first groundwater management areas were proclaimed in the 1970s, and virtually the whole state was proclaimed within two decades. Different states use different terminology for these management areas, but nationally they are referred to as groundwater management units (GMUs).

State agencies undertake activities such as exploratory drilling, groundwater assessments and maintenance of monitoring networks as part of their management responsibilities. Intergovernmental coordination is facilitated through the Council of Australian Governments (COAG). This enables development of reforms of national significance, such as the National Water Initiative and the Murray-Darling Basin Plan. It also provides for national overviews, such as Australian Water

- Outback water storage tank and windpump near Alice Springs, Northern Territory. o Getty Images [P Walton] 
Resources 2005, which indicated the following for Australia:

- There are 367 groundwater management units, for which $33 \%$ have a draft or final management plan in place.

- About $5 \%$ of groundwater management units are overallocated, meaning that the total groundwater volume that can be extracted exceeds the environmentally sustainable level that has been defined (Figure B7.2). Although only a small proportion of the total groundwater management units are overallocated, these do include some of Australia's major groundwater resources. A further $23 \%$ of groundwater management units are classified as highly developed.

- There are areas of particular groundwater development, such as near-urban areas in the nation's west-Alice Springs and Darwin (NT), Perth (WA); irrigated alluvial valleys in the east, such as the Namoi and Lachlan (NSW); and key areas with limited or episodic surface water, such as the Great Artesian Basin.

A new injection of funding from the Australian Government was initiated in 2008, principally under the National Water Commission's \$82 M Groundwater Action Plan. Also, under the Commonwealth Water Act 2007, the Bureau of Meteorology is charged with the national compilation and delivery of water information, and is currently building capacity to store national statistics on groundwater use from metered bores and groundwater levels from monitoring bores.

Groundwater managers are facing increasing complexity in fully allocated systems, with the advent of trading, integration of surface-water and groundwater management, extension of metering and consideration of water resource management charges to be levied on users. The need for complex numerical models to assist in determining sustainable yields, and tools to assess trading

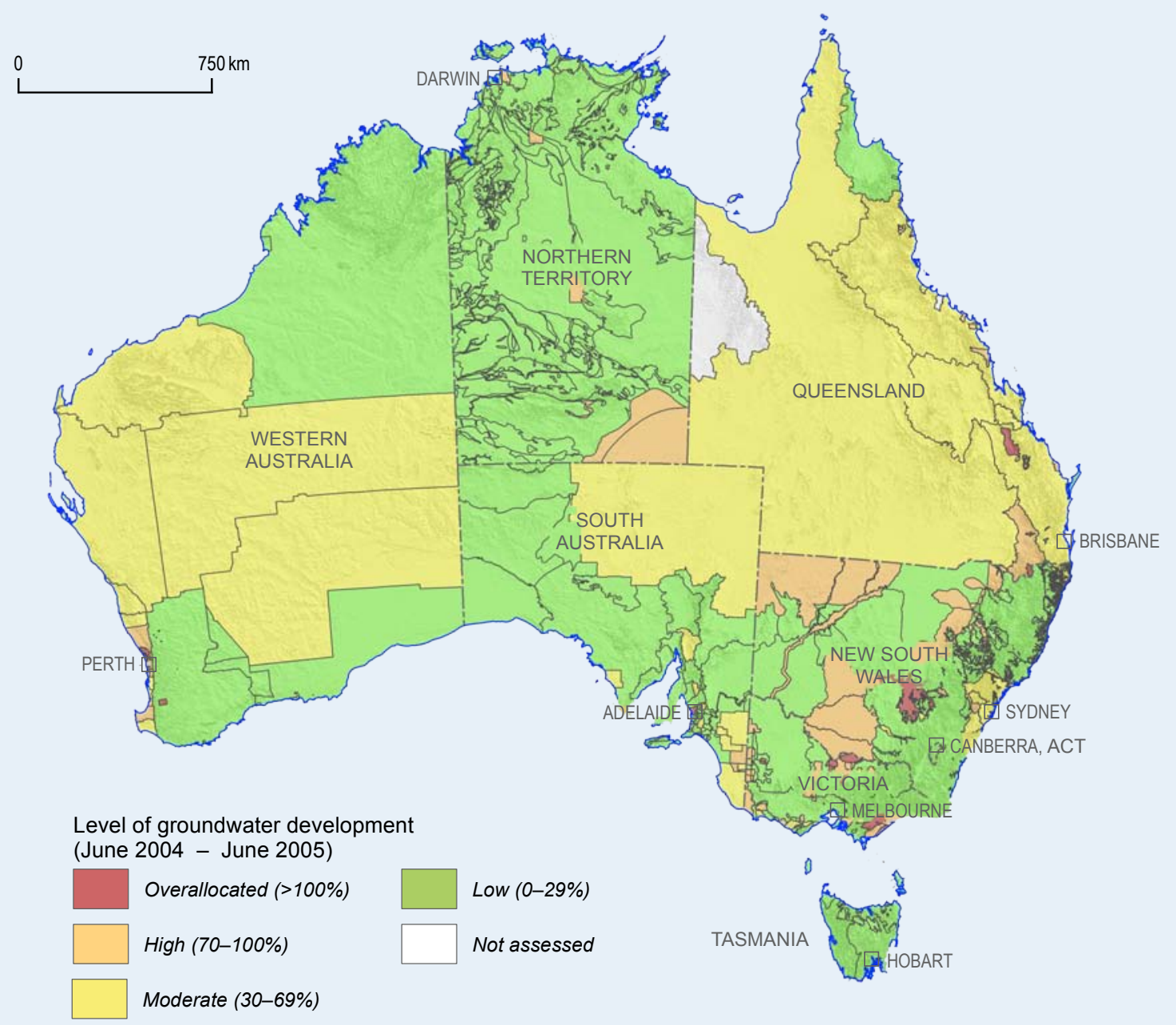

of groundwater allocations means increased demand for hydrogeologists and groundwater managers. This need was recognised by the funding, from 2009, of a new National Centre for Groundwater Research and Training, based in Adelaide. The challenge for the next generation of hydrogeologists is to improve understanding of the geology of aquifers, aided by 3D geological models, to build better numerical representations reflecting heterogeneity, and to better understand recharge processes and climate change impacts.
Figure B7.2: National map of level of groundwater development, as sourced from the Australian Water Resources 2005 national assessment. The level of development within groundwater management units is classified by comparing entitlements with the defined sustainable extraction limits. Dark-orange areas are overallocated groundwater management units, and light-orange areas are highly developed groundwater management units. (Sources: National Water Commission, 2006; Geoscience Australia 


\section{Did know?}

\section{3: Aussies like to drink!}

Australians are large users of water, consuming $920 \mathrm{~kL}$ of water per capita in 2004-05. This figure includes water used in agriculture, by other industries and by households. On a per-person basis, the 2004-05 water consumption was $18 \%$ lower than in 2000-01 (1100 kL per capita). Agricultural water consumption per person also decreased over this time, from $772 \mathrm{~kL}$ per capita in 2000-01 to 598 kL per capita in 2004-05.

Average domestic (household) water use also declined from $117 \mathrm{~kL}$ per capita in 2000-01 to $103 \mathrm{~kL}$ per capita in 2004-05. In 2008-09, the Water Services Association of Australia calculated domestic water use in the capital cities at $43.6 \mathrm{~kL}$ per capita. The lowering of per-capita (and total) water use coincided with prolonged drought, which resulted in the introduction of tough water restrictions and reduced availability of water for agricultural purposes.

\begin{tabular}{|c|c|c|c|c|c|c|c|c|}
\hline & 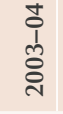 & $\begin{array}{l}\text { Lo } \\
\text { ț } \\
\text { ồ }\end{array}$ & 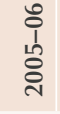 & $\begin{array}{l}\text { ô } \\
\text { dे } \\
\text { ڤે̀े }\end{array}$ & $\begin{array}{l}\text { o } \\
1 \\
\hat{1} \\
\hat{े}\end{array}$ & 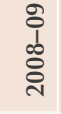 & ڤัँ & 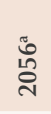 \\
\hline Adelaide & 105 & 101 & 101 & 102 & 84 & 83 & 85 & 71 \\
\hline Brisbane & 102 & 104 & 73 & 60 & 51 & 53 & 84 & 84 \\
\hline Canberra & 97 & 94 & 104 & 95 & 76 & 79 & 93 & 78 \\
\hline Melbourne & 77 & 74 & 75 & 68 & 60 & 57 & 63 & 59 \\
\hline Perth & 111 & 107 & 105 & 110 & 104 & 106 & 87 & 76 \\
\hline Sydney & 83 & 78 & 75 & 74 & 68 & 74 & 70 & 63 \\
\hline
\end{tabular}

Residential water use per capita ( $k \mathrm{~L})$

a Projected water use

(Sources: Australia Bureau of Statistics 2010; Water Services Association of
Groundwater use, particularly for irrigation, has rapidly expanded over the past three decades. This reflects the prolonged periods of drought over this time, combined with the transfer of demand due to capping of surface-water licences. In the Murray-Darling Basin, groundwater extraction has practically doubled since the 1990s. In 2009, nearly 2500 GL of groundwater was used across Australia to irrigate crops and pastures, which represents a third of the total use. The regulation of water in Australia is linked to the country's federation. Water is a state or territory responsibility, but the flow of water of course does not know of these political boundaries (see Box 7.2).

\section{The people's groundwater: supply for cities, towns and communities}

Many rural and remote communities across inland Australia rely on groundwater for their water supply. The discovery of the Great Artesian Basin was a boon for inland town water supplies, with artesian bores serving 24 towns in Queensland by 1900 . Alice Springs is strategically located in the geographical centre of Australia and is an important Indigenous, pastoral, mining, tourist, transport and communications hub. Most of the town water supply is from the Roe Creek borefield, accessing the Devonian Mereenie Formation in the Amadeus Basin. More than $250 \mathrm{GL}$ of groundwater have been pumped since the establishment of the borefield in 1964, to service an average consumption of $1000 \mathrm{~L} /$ person/day-a considerable amount for a region with average annual rainfall only $286 \mathrm{~mm}$. Groundwater has also played a long-established role for communities closer to the coast. For example, by 1910, some
40 artesian bores had been drilled for public or institutional supply for the Western Australian capital, Perth.

Extraction from Roe Creek borefield now exceeds modern recharge, as the groundwater levels in the borefield continually drop by more than $1 \mathrm{~m} /$ year. This is because the groundwater supply is essentially 'fossil water' or palaeowater, being derived from a previous wet period, and not now significantly being recharged. Such aquifers can be found in most arid regions and may not have been replenished for thousands or even millions of years, depending on the palaeoclimatic record. Australia is not alone in its reliance on groundwater. Depletion of fossil water is effectively mining the resource, with notable examples in the United States, the Middle East, North Africa and parts of Asia. It is acknowledged that long-term dewatering will occur in the Mereenie aquifer, and management is focused on reducing operating costs and delaying major investments such as a new borefield.

For most of the 20th century, however, there has been a surface-water focus to service the needs of the $80 \%$ of Australians who live on the coastal fringe (Chapter 6; Did you know? 7.3). This was through the construction of major dams in the hinterland catchments around the Australian capitals. The 2009 National Water Accounts estimated that surface water made up 96\%, or nearly 9000 GL, of the water supply for Australians. Long drought conditions through the 1990s-2000s and rising average temperatures have provided a renewed impetus to bring groundwater back into the provision of urban water supplies. This impetus came early for the southwest corner of Western 
a.

Trend in mean annual temperature $\left({ }^{\circ} \mathrm{C} / 10\right.$ years $)$

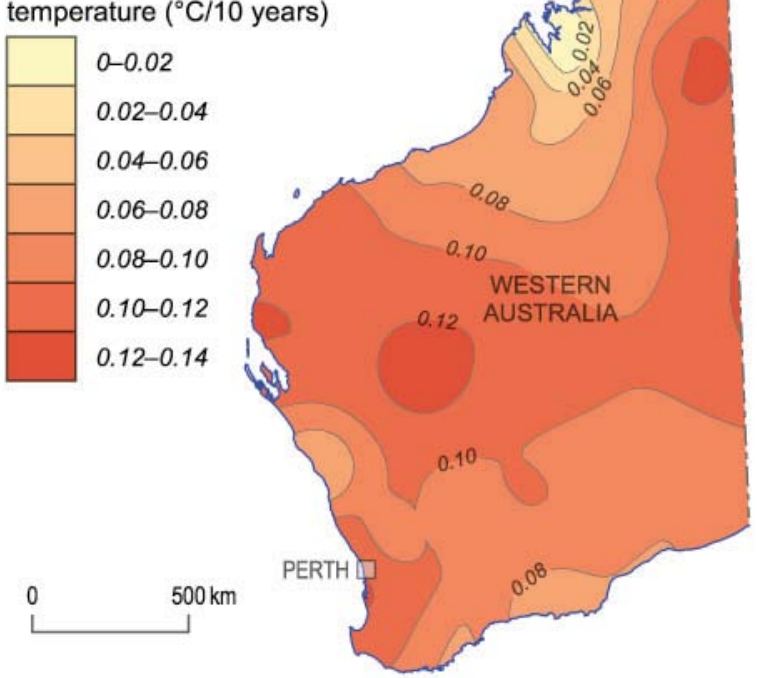

Australia (Figure 7.9a and b). Since 1975, there has been a $15 \%$ decline in winter rainfall, reflected in runoff into Perth metropolitan dams being reduced by $75 \%$ (Figure $7.9 \mathrm{c}$ ). To make things even worse, climate models predict further rainfall declines, in the order of $20 \%$ by 2030 .

A more diversified and integrated approach to urban water supply has been the response. Surface-water reservoirs are still vital, but $35-50 \%$ of urban supply is derived from groundwater and 15-20\% from seawater desalination. Perth is blessed with a favourable distribution of coastal plain sandy sediments that, combined with the structure and sedimentology of underlying Mesozoic rocks (Figure 7.10), provides a number of significant fresh groundwater resources, including:

- the Gnangara Mound, a 70-m thick water-table mound within Quaternary sands north of Perth, which is the single biggest contributor to the city's urban water supply b.

Trend in annual total rainfall (millimetres/10 years)

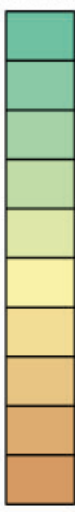
20-30

15-20

$10-15$

5-10

$0-5$

0 to -5

-5 to -10

-10 to -15

-15 to -20

-20 to -30

0 $500 \mathrm{~km}$

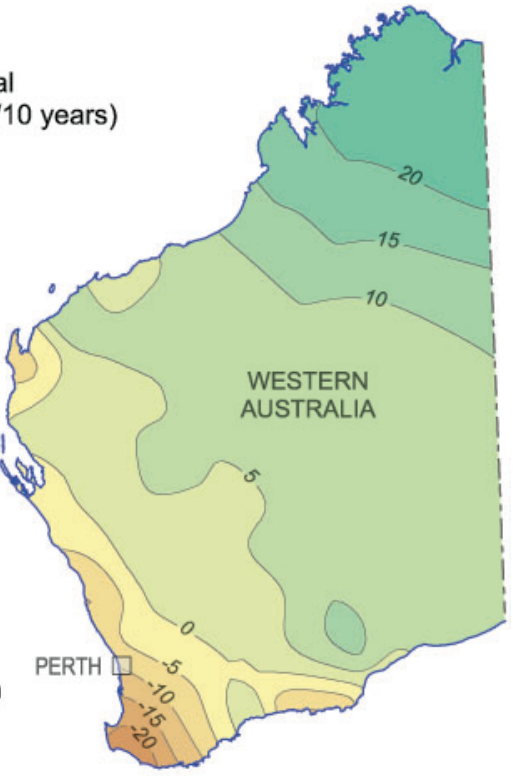

- the Jandakot Mound, a similar but smaller shallow unconfined groundwater resource to the south of Perth

- the Leederville Aquifer, formed within Early Cretaceous marine sandstones in the Perth Basin and about $500 \mathrm{~m}$ thick

- the Yarragadee Aquifer, a significant Jurassic confined freshwater aquifer in the Perth Basin and underlying the Leederville Aquifer. Groundwater in the Yarragadee Aquifer has been dated at $>40 \mathrm{ka}$, and fresh groundwater extends well offshore, reflecting the period when sea-level was lower and the continental shelf was emergent land (Chapter 1). Current annual extraction for urban water supply is about $45 \mathrm{GL} /$ year.

As Perth is built on sandy Quaternary coastal plain sediments, this shallow unconfined aquifer has long been used by householders for garden watering during the hot, dry summers. It is

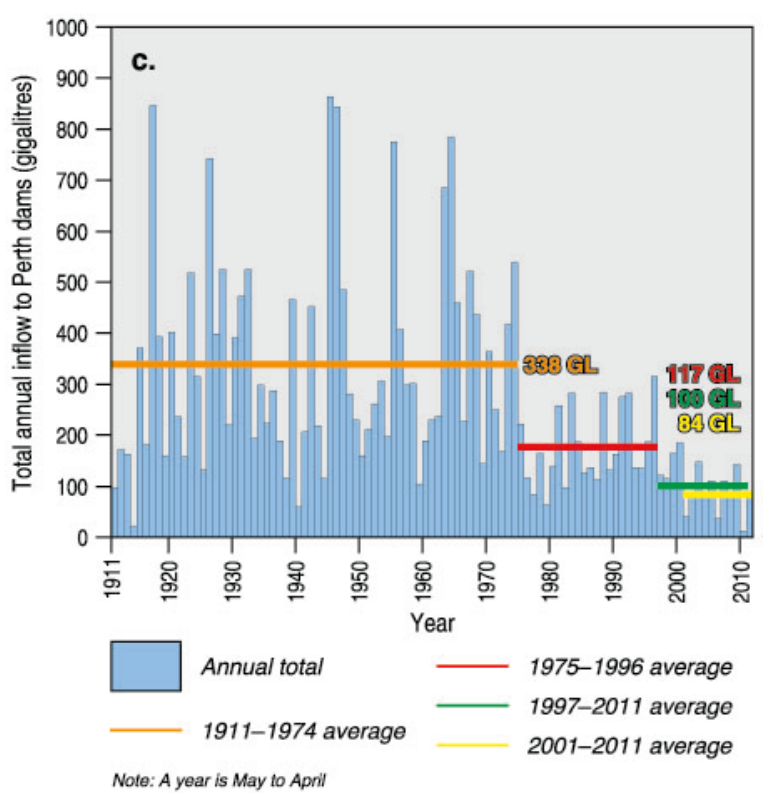

Figure 7.9: Changing climate in Western Australia. The most dramatic changes are occurring in the southwest of the state, where most of the population lives (Figure 1.3). (a) Increasing trends in mean annual temperatures, Western Australia. (b) Downward trend in mean annual rainfall, Western Australia. (c) Declining annual streamflow into Perth dams. (Sources: Western Australia State Water Plan, 2007; Bureau of Meteorology, 2011) 

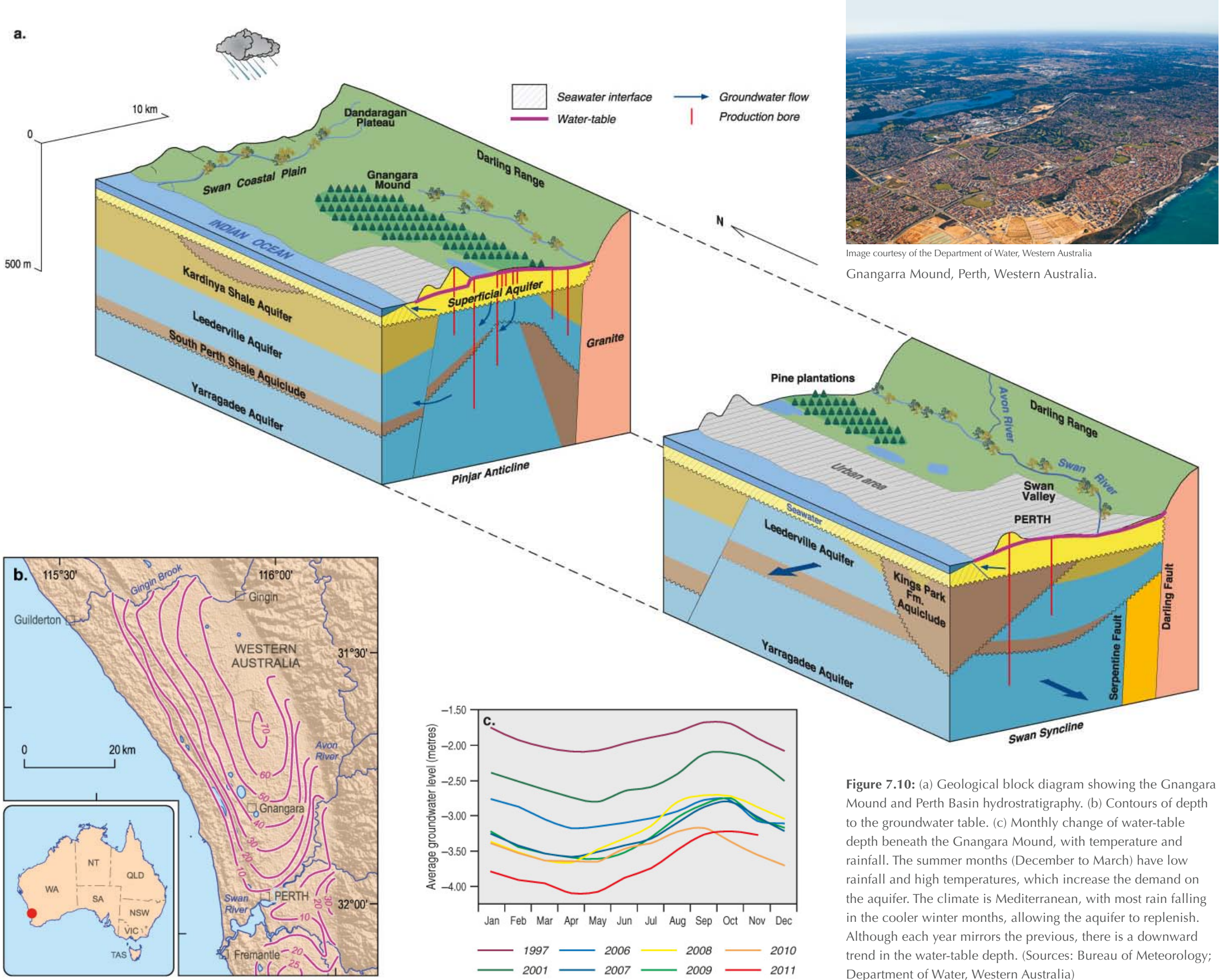

Gnangarra Mound, Perth, Western Australia.

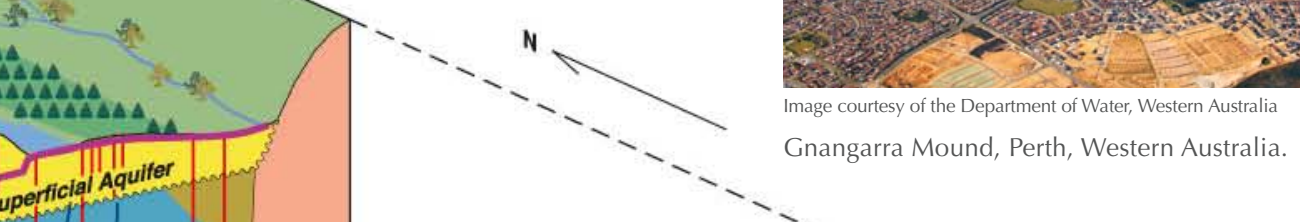




\section{Did know?}

\section{4: Rain doesn't necessarily follow the plough}

One story-just one phrase-can acquire exceptional prominence and power as a description of a place, if not a determinant of its future. 'Rain follows the plough' is one example from the late 19th century. At that time, there was intense debate in Australia over whether clearing of native forest (trees, 'bush') for pastoralism or agriculture increased or reduced rainfall. One side had a potent phrase; the other did not. The result of this linguistic imbalance, almost certainly, was more clearing, as 'rain follows the plough' became a mantra that encouraged often unsustainable agriculture and enduring environmental cost.

Popular enthusiasm for irrigation as a basis for agriculture was intense, with the poet Henry Lawson (Chapter 8) one of its keenest advocates. Now, as irrigation assumes proportions Lawson never imagined, its impact is arousing increasing concern. 'When the river runs backwards' is phrase still gaining life-a powerful warning that natural processes are being overturned, putting the environment in jeopardy.

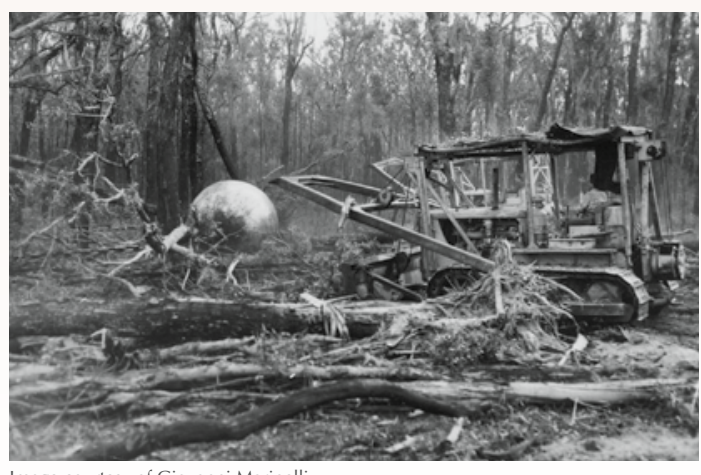

Clearing trees in the 1950s, southwest Western Australia. substituting $20 \mathrm{ML} /$ day of its surface-water supply, locating a number of small to moderate groundwater supplies. About $100 \mathrm{~km}$ inland, authorities in Toowoomba drilled bores into the Jurassic Helidon Sandstone of the Great Artesian Basin as the water situation became critical.

\section{Bore water, mineral water: it's all groundwater}

Groundwater can be many things to many people. Mention 'bore water' to Australians and the response may be somewhat negative. Memories can be triggered of trying to shower or launder using hard bore water. The smell of hydrogen sulfide or taste of iron may return. These concerns can be legitimate as groundwater contains a range of dissolved constituents. Salinity is the major water-quality factor, usually reflected in high $\mathrm{NaCl}$ contents, but there are other natural constituents that may preclude certain uses, in spite of the overall salinity. For example, throughout inland Australia, nitrate, even in fresh groundwater, frequently exceeds the drinking water guideline of $50 \mathrm{mg} / \mathrm{L}$. This imbalance is a health concern due to the possibility of methemoglobinaemia (blue baby syndrome). The elevated nitrate levels are not due to agricultural contamination, but reflect bacterial activity in the arid soils.

Compare this with the response when 'mineral water' is mentioned to Australians. A smorgasbord of images may come to mind-pure and natural, exotic and sophisticated, health and vigourdepending on the demographic being targeted by the bottling companies. Drinking mineral water was not a British heritage, but began with brands from many European countries being imported for migrant communities and then promoted widely through restaurants. Bottled water, for both bulk and individual consumption, started to become popular in the 1980s. By 2010, it had evolved into a \$560 M industry serving 19\% of Australians. However, public concerns are emerging about the environmental impact of producing, transporting using and disposing of plastic water bottles. In 2009, the town of Bundanoon, $150 \mathrm{~km}$ inland of Sydney, became the first Australian town to ban the sale of bottled water. This was followed by the University of Canberra in the nation's capital, which became the first university to place such a ban

The other traditional use of groundwater is for baths (see Box 7.3).

\section{Groundwater: a geological agent of change}

European settlement has clearly brought profound change to the Australian landscape. In the previous section, we described some of the history and implications of groundwater resource development across Australia. However groundwater is part of the hydrological cycle (Figure 7.2); it is intrinsically connected to the land, rivers, ecosystems and, therefore, people. Modifications to groundwater systems can have broad and sometimes unanticipated implications and, as such, groundwater can be viewed as a geological agent of change. 


\section{TAKING THE WATERS (воx 7.3)}

The Daylesford-Hepburn Springs area located in central Victoria is known as Spa Country, famous for its carbonated water springs. In 1864, its citizens petitioned the Victorian Government for the mineral springs to be protected from the impacts of mining. Many of the town residents were from European countries with a spa heritage, including Switzerland, Italy, Germany and England. The residents appreciated the water's intrinsic value, above that of gold, which led to the creation of the Hepburn Mineral Spring Reserve. The area was a popular destination for Melburnians to 'take the waters' after the arrival of the railway in 1880, but patronage of the spas declined from the 1920s. There has been a resurgence in recent decades, with facilities upgraded to accommodate a renewed interest in 'wellness': natural healing, hydrotherapy and spa relaxation.
There are more than 100 documented springs in the area, typically located in river valleys and streambeds. The spring waters are naturally effervescent and mildly acidic, and have low chloride $(<80 \mathrm{mg} / \mathrm{L})$ and high bicarbonate $(>1400 \mathrm{mg} / \mathrm{L})$. Their ambient temperature suggests a shallow water circulation in the order of hundreds of metres, supported by the silica geothermometry. The groundwater is sourced from local rainfall recharge, but carbon isotope data link the $\mathrm{CO}_{2}$ to volcanic activity. The area has the highest concentration of eruption points in the Newer Volcanic Group.

The Victorian Spa Country is not the only place in Australia to visit spas. The Japanese-themed Peninsula Hot Springs geothermal complex on the Victorian Mornington Peninsula uses groundwater at $50^{\circ} \mathrm{C}$ from a $637 \mathrm{~m}$ deep artesian bore (Figure B7.3). Further afield, artesian baths dotted across the vast expanse of the Great Artesian Basin provide a truly unique outback spa experience. Hot mineralised artesian groundwater is used in public baths and swimming pools in some of the country towns-the Moree Hot Artesian Pool Complex (NSW) uses artesian groundwater at $40^{\circ} \mathrm{C}$ from an $868 \mathrm{~m}$ deep bore to create this town's major tourist attraction and the focus for its annual Healing Waters Festival. In other parts of Australia, there are examples of hot springs providing pleasure for tourists and locals alikethe Mataranka, Katherine and Tjuwaliyn springs (NT), Hastings Cave (Tas.), Zebedee Springs in the Kimberley (WA) and Innot hot springs (QId) (Figure B7.3).

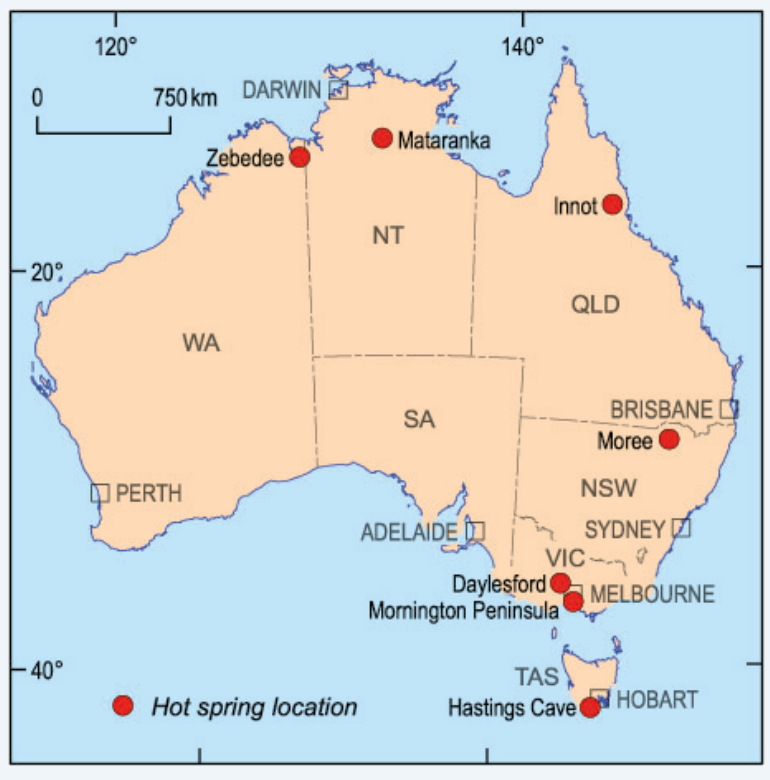

Figure B7.3: Location of some Australian hot springs.

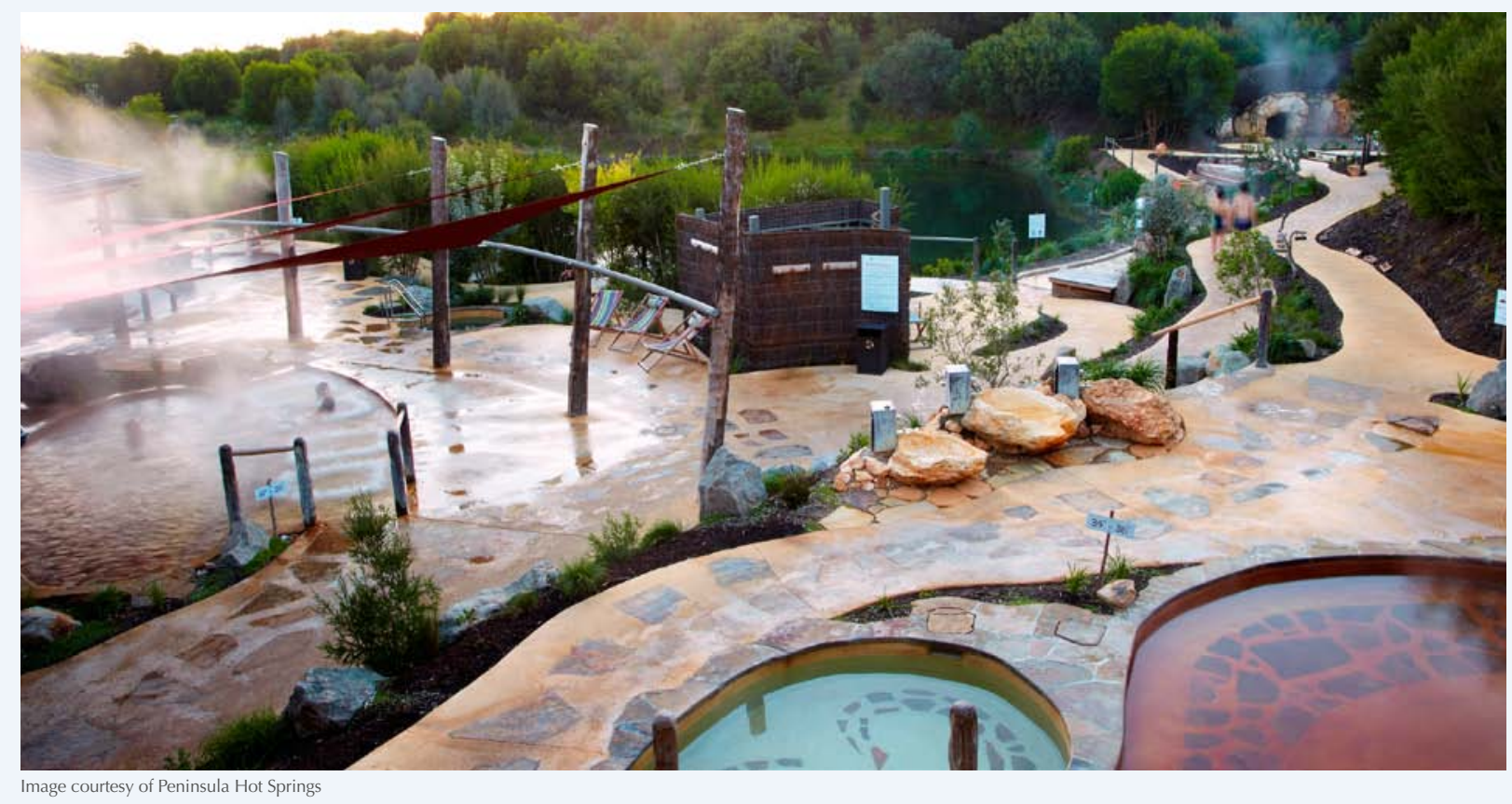




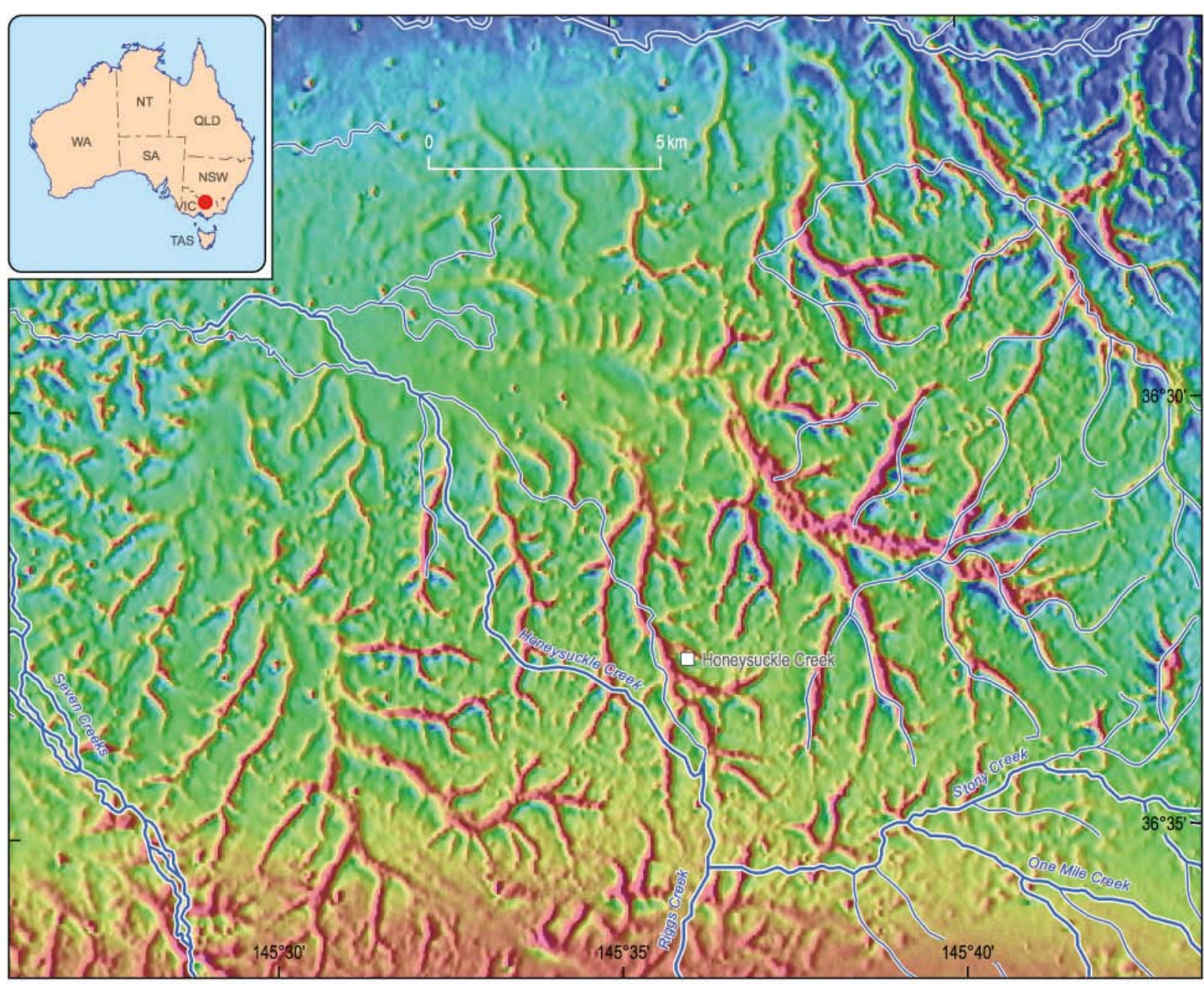

Figure 7.11: Total magnetic intensity (1st vertical derivative) of the Honeysuckle Creek area of the southern Murray Basin, near Shepparton (Vic.). The red colours are magnetic highs; blue colours are magnetic lows. The dendritic pattern mapped by the magnetic data is caused by clasts containing maghemite that were deposited in a Plio-Pleistocene palaeodrainage network. These palaeodrainage networks are the 'deep leads' that may contain rich accumulations of alluvial Au (Chapters 5 and 8), as well as groundwater. They are now covered by young alluvium. The present-day drainage follows some of these old paths, but deviates markedly in many places. (Source: Gibson \& Wilford, 2002) baseflow can be critical to maintaining river flow and aquatic ecosystems during dry periods. Further downstream, the river may actually lose water to the underlying alluvial aquifer; this should not necessarily be viewed as a 'loss' as it can replenish a significant groundwater resource.

A geological understanding of the catchment, therefore, is a precursor to understanding the interactions between groundwater and surface water. Mapping the distribution of restrictive clay layers (aquicludes or seals) or, alternatively, palaeochannels (aquifers) that act as preferential pathways is important (Figure 7.1). Also important is identifying geological structures such as faults or basement highs that control the geometry and hydraulic properties of aquifers (Figure 7.10a). For example, in the Cudgegong Valley, $250 \mathrm{~km}$ inland of Sydney, bedrock highs or faulting constrict groundwater throughflow in the alluvial aquifer, resulting in shallower water-tables and gaining conditions in the river. Away from these geological features, the regulated Cudgegong River is largely a losing stream.

Surprisingly, the importance of river-aquifer connectivity to water allocation has only recently been recognised in Australia (Figure 7.12). Water management in the Murray-Darling Basin is symptomatic of this. In 1997, a cap was placed on the volume of surface water diverted from the river system; however, basin groundwater use was not constrained. Combined with drought conditions, groundwater use increased steeply with migration of demand. Groundwater now accounts for 16\% of total water use in the basin, but a far greater 
proportion during droughts. By 2030, groundwater could make up more than $25 \%$ of total average basin water use. Of concern is how current and projected increases in groundwater extraction will decrease baseflows to rivers, particularly during low-flow conditions, so impacting on the integrity of the surface-water cap. It is also estimated that $25 \%$ of current groundwater use will eventually be sourced from river 'leakage' induced by the water-table declines from groundwater pumping. As recently as 2005 , double accounting, where the available resource is counted as both a surface-water and a groundwater stock, was occurring in the national audit because of a failure to understand the extent of the connectivity. A conjunctive approach is required, in which groundwater and surface-water resources are managed in a coordinated way.

\section{Change and the groundwater- wetlands connection}

Colonial settlers in Australia typically considered wetlands as unsanitary and of little value, and as a consequence wetlands were drained, progressively filled in, or used as refuse tips. Fortunately, public perception has changed with increasing environmental consciousness, and the signing of the 1971 intergovernmental UNESCO Ramsar Convention for the 'conservation and wise use of wetlands and their resources'. Public interest has spurred the need to better understand wetland hydrology, including groundwater linkages.

The wetlands of the Gnangara Mound, north of Perth, are a classic example of groundwater and surface-water interaction (Figure 7.10). Here, an elevated dune plain is the surface expression of

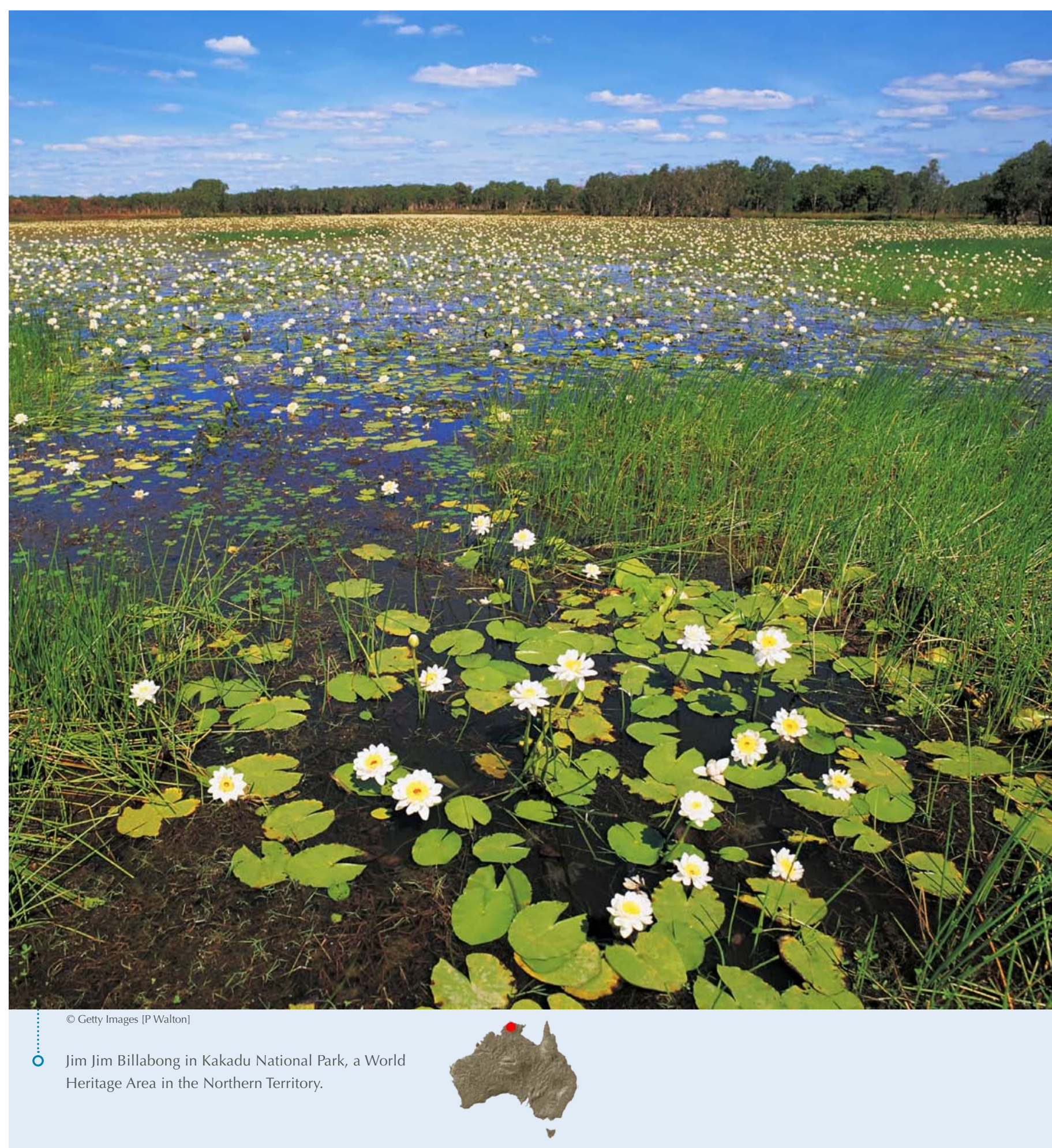




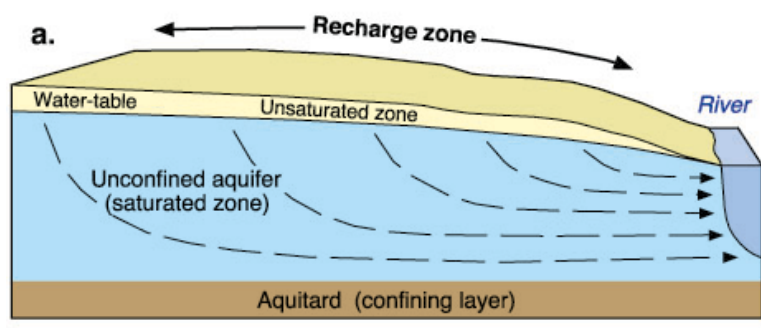

b.

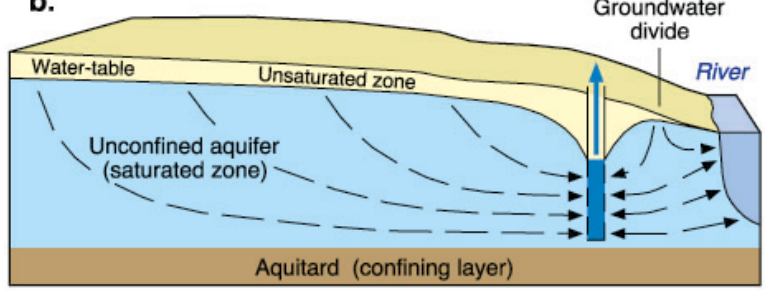

c.

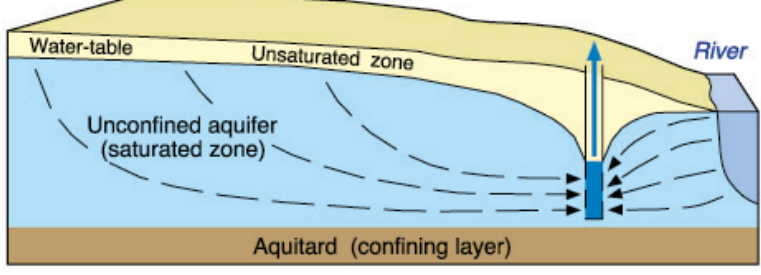

Figure 7.12: Impact of shallow groundwater extraction near rivers. (a) Pre-extraction state of groundwater and river water, where groundwater flows towards the river. (b) Drilling of a bore adjacent to a river will deflect the groundwater flow towards the bore. (c) Ongoing extraction may eventually draw water from the river into the bore. Note the lowering of the water-table around the bore- - this is called a cone of depression. (Source: Winter et al., 1998)
Quaternary coastal sands hosting a groundwater mound, some $70 \mathrm{~m}$ thick. Wetlands occur in the interdune depressions and are windows to the shallow water-table. As such, the wetland hydrology is defined by the groundwater trends, which reflect medium-term rainfall cycles. The rainfall record, expressed as the cumulative departure from the mean, shows that until 1914 there was a relatively dry period, followed by a wet period from 1915 to 1975 , before another dry period (Figure 7.9c). Groundwater trends are shown by the change from swamps to lakes around 1920, and the reversion to swamps in the late 1970s. Also, the water balance of the Gnangara Mound is controlled by the wetlands. At high water levels, evapotranspiration is increased, and this is diminished when groundwater levels fall and wetlands dry up.

\section{The offshore realm: change and submarine groundwater discharge}

Aquifers can extend offshore, allowing the opportunity for submarine groundwater discharge. This flow can influence the distribution of freshes (low-salinity zones), nutrients and contaminants in the marine environment. The existence of submarine discharge of groundwater has long been recognised in Australia. In the local language of the Guggu Yimithirr of eastern Cape York Peninsula, freshwater is buiur, and buiur bindi is a spring in the ocean, referring to groundwater discharge in the intertidal zone. In 1896, Queensland Government Geologist RL Jack, when examining the water budget for the Great Artesian Basin, pondered that:
The bores and springs combined do not give out the tithe of the water absorbed every wet season, and, as the water does not escape by land, and can hardly be supposed to find a hiding-place in the centre of the Earth, the only alternative is that it must escape where the absorbing strata crop out beneath the floor of the ocean. I have been informed by a thoroughly reliable shipmaster that there is a spot far out in the Gulf of Carpentaria where almost fresh water can be taken up in a bucket.

Direct evidence of submarine groundwater discharge can be found along the lagoon of the Great Barrier Reef (Chapter 6). Fresh groundwater emanates from seafloor depressions, called 'wonky holes' by the local fisherman because they are a hazard to trawling equipment. These features are circular, $10-30 \mathrm{~m}$ across, and found in about $20 \mathrm{~m}$ of water depth within $10 \mathrm{~km}$ of the Queensland coastline (Figure 7.13). They are interpreted to be associated with palaeochannels incised into the shelf during sea-level lowstand that are filled with coarse sediment and capped by finer terrestrial material during later Holocene sea-level rise. Sea life is relatively prolific near these holes, but there are concerns that these springs are also conduits for agrochemicals, excessive nutrients or acid waters from the land, which could have a negative impact on the World Heritage coral reef (Chapter 6).

\section{Changing groundwater impacts on Australia's unique ecosystems}

There is increasing awareness of the groundwater dependency of many of Australia's unique ecosystems. As aquifers can contribute to rivers, 
wetlands and estuaries, many aquatic ecosystems can have at least a partial reliance on groundwater. Groundwater can provide critical baseflow to rivers during dry periods and thus sustain life. The platypus needs perennial stream flow or refuge pools, making it a signature species in this regard. Discrete springs within rivers can provide a stable environment for unique and specialised biota. This is also the case for the hyporheic (mixing) zone between surface water and groundwater found in the permeable riverbed sediments. This mixing encourages biological and chemical activity, creating a greater diversity of microfauna than in the river itself.

More broadly, many Australian vegetation communities also rely on shallow groundwater sources, particularly in periods of prolonged drought. The river red gum forests of the MurrayDarling Basin and the Banksia woodland on the Gnangara Mound of Perth are just two examples. Root access to the water-table via the capillary zone can be permanently, seasonally or opportunistically important. The depths to which trees send down their roots in search of water can be surprising. Rooting depths of $40 \mathrm{~m}$ have been observed for jarrah trees in Western Australia, and studies of bloodwoods in central Australia showed groundwater uptake from $20 \mathrm{~m}$ depth. The true extent of the groundwater dependency of Australia's flora has yet to be discovered.

As the links between groundwater and ecology are many and varied, there is a veritable groundwater menagerie. Here are just some examples of Australian fauna that have a dependency on groundwater:
- Native animals of the semi-arid interior have a groundwater reliance because springs and soaks are critical refuges, particularly during droughts. This is the case also for the diversity of birdlife, so much so that Aboriginal people sighted and tracked the more sedentary species, like zebra finches, pardalotes and various pigeons, using them as desert water diviners.

- Investigations at the Mon Repos beach turtle rookery near Bundaberg (Qld) suggest that groundwater conditions can influence the breeding cycle of loggerhead turtles. Eggs are laid in chambers about $0.5 \mathrm{~m}$ into the moist sand, within the capillary zone above the shallow water-table. This provides ideal conditions for incubation, including high humidity, low salinity and adequate ventilation. Too wet and the eggs become inundated; too dry and the chamber collapses while being dug.

- Groundwater can have an influence on dugongs, the 'cows of the sea' that graze offshore seagrass beds. Submarine groundwater discharge can be an important contributor of nutrients to such offshore habitats, particularly where marine upwelling or river discharge is limited. For example, studies of seagrass and kelp beds north of Perth estimated that half of the nitrogen required for growth came from groundwater discharge.

- Groundwater conditions can obviously have an overriding influence on cave ecosystems. On the southwest tip of Western Australia, eucalypt tree roots access groundwater within the caves of the Leeuwin-Naturaliste Ridge. In turn,
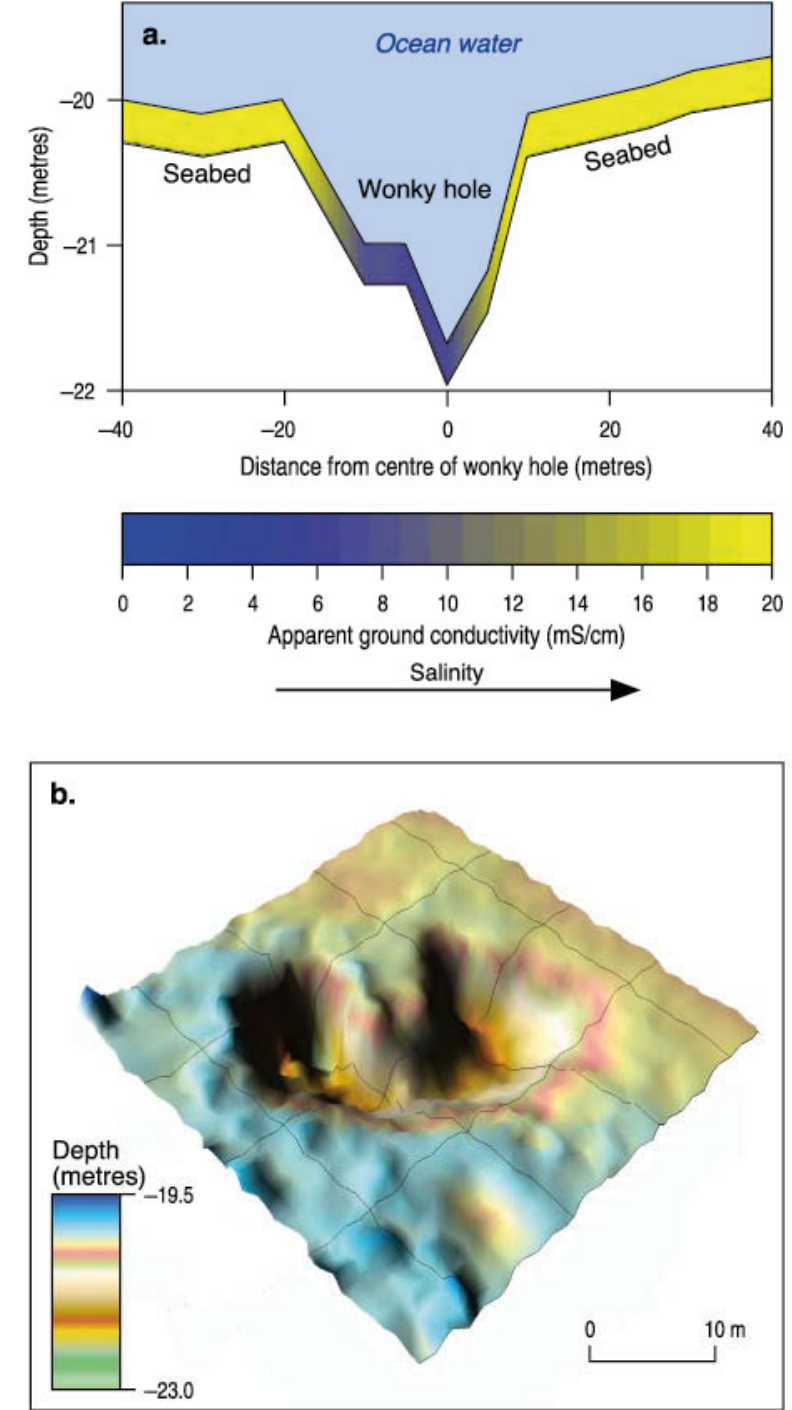

Figure 7.13: Example of a 'wonky hole' associated with submarine groundwater discharge in the lagoon of the Great Barrier Reef. (a) Apparent ground conductivity transect, showing significantly reduced conductivity due to the freshwater from the 'wonky hole' depression. (b) Mapping of the seafloor depression by acoustic multibeam imagery. (Source: Dr Thomas Stieglitz, School of Engineering and Physical Sciences, James Cook University, Townsville, 2005 


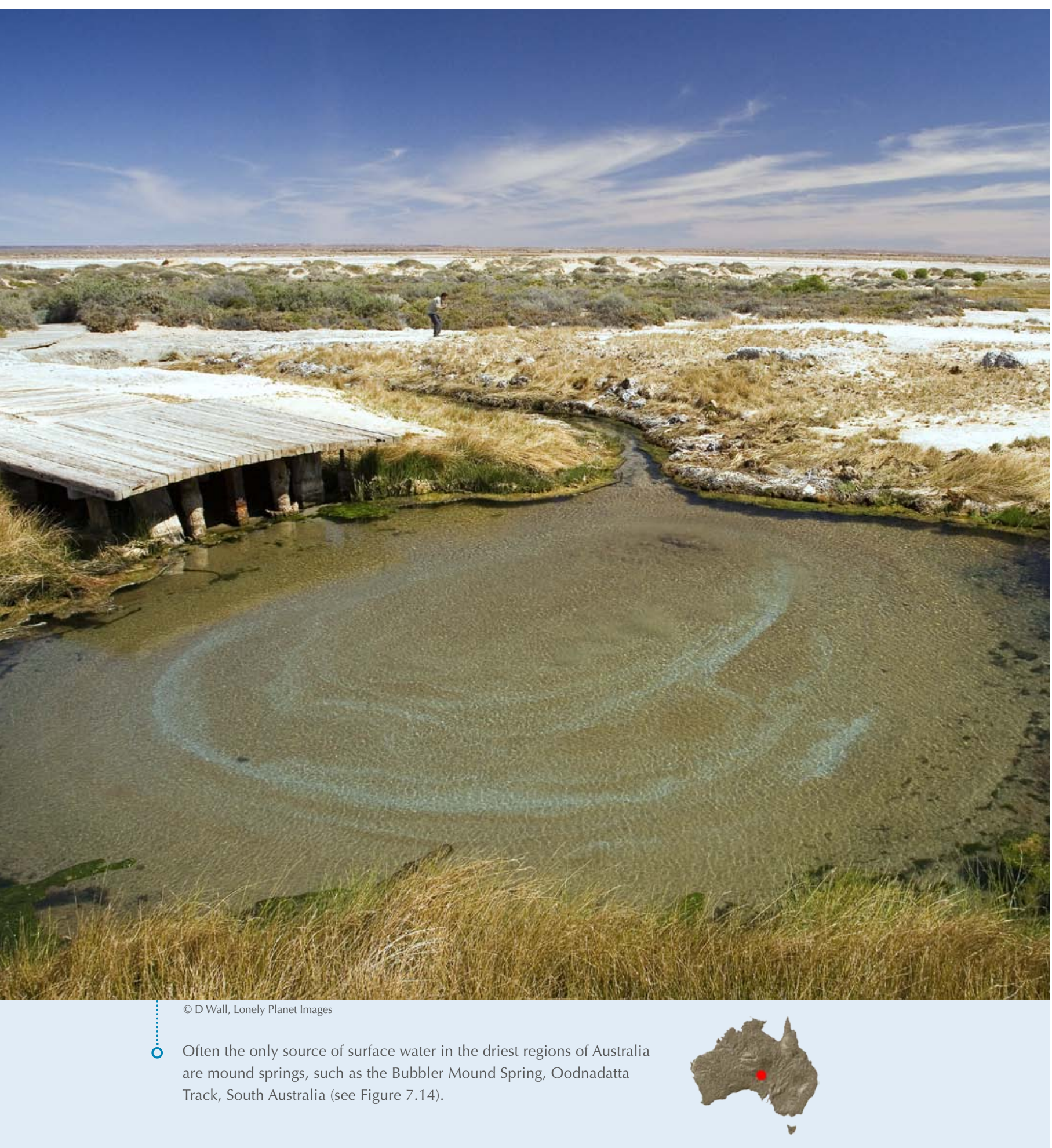

the root-mat and fungal growths support a complete food web and one of the richest cave fauna communities in the world. This ecology is threatened by declining groundwater levels, thought to be a consequence of lower rainfall (Figure 7.9b). A similar situation prevails for root-mat ecosystems found in caves near Yanchep, about $50 \mathrm{~km}$ north of Perth, which rely on groundwater of the Gnangara Mound. Sprinkler systems have been installed to maintain moisture for the root mats.

- Animals have been found to be living in the void spaces within aquifers. Such 'stygofauna' are mostly crustaceans, but also include insects, worms, gastropods and mites. These animals display the evolutionary features of a subterranean existence, including no or limited eyes or pigment, enhanced non-optic senses and a worm-like body form. A diverse array of endemic species has been found within shallow calcrete aquifers associated with Cenozoic palaeovalleys in Western Australia.

\section{The mound springs of arid Australia: a unique ecosystem}

Near Lake Eyre in the arid northern part of South Australia, you will find that the most reliable water supply is not the lake but on top of the hills (Figure 7.14). Groundwater discharge from the Great Artesian Basin has precipitated carbonates and other minerals, which, when combined with windborne sediments, have created conical mounds that dot the flat, arid landscape. The active mound springs typically range up to $10 \mathrm{~m}$ in height, but there are ancient relict spring deposits that rise 
$40 \mathrm{~m}$ above the surrounding plains. About $60 \%$ of the estimated total spring discharge across the basin of $1500 \mathrm{~L} / \mathrm{s}$ occurs in South Australia.

The mound springs have great heritage significance (see Did you know? 7.5). They represented reliable drought refuges for local Aboriginal people and were an important part of a continent-wide Indigenous communication and trading route. The Witjira-Dalhousie Mound Springs, $350 \mathrm{~km}$ north of Lake Eyre (Figure 7.14), for example, are renowned for the extent and volume of Aboriginal artefacts. These springs feature strongly in the Wangkangurru people's song-lines and story-lines.

The mound springs were also important for the Europeans. The springs were used by explorer John McDouall Stuart, the first European to cross the continent from south to north in 1862 . He defined the route for the Overland Telegraph between Adelaide and Darwin, which, when completed in 1872, revolutionised communication with Britain and the rest of the world.

Mound springs are emblematic for groundwaterdependent ecosystems. They represent island habitats in a desert 'sea', and contain many rare and endemic species of plants, fish, snails, isopods, amphipods and ostracodes. Living in the WiljiraDalhousie Mound Springs are four endemic fish species (Dalhousie catfish, Dalhousie hardyhead, Dalhousie mogurnda and Dalhousie goby), as well as unique snails and crustaceans. In 2001, all Great Artesian Basin discharge springs were collectively listed under the Commonwealth Environment Protection and Biodiversity Conservation Act 1999 as an endangered ecological community.
The complex of mound springs extends over an area of approximately $400 \mathrm{~m}$ by $500 \mathrm{~m}$. This complex has groundwater flow that deposits $\mathrm{Ca}$ and other salts from the mineral-rich waters, and these deposits, combined with windblown sand, mud and accumulated plant debris, settle around the spring outflow, forming mounds that resemble small volcanoes. Elizabeth Springs was added to the National Heritage List in August 2009 as it is a significant refuge for a number of plants and animals that, due to the springs' isolation, have evolved into distinct species not found anywhere else in the world, including a freshwater hydrobiid snail and the threatened Elizabeth Springs goby.

\section{Change and the geological inheritance of salinity}

In southern Australia, groundwater salinity can be high as a result of interior drainage and high salt storage in the unsaturated zone. Both these factors have contributed to the salinisation of farmland and surface waters. The link between land clearing and salinisation was first documented in 1924 by railway engineer Walter $\mathrm{E}$ Wood in Western Australia. In the steam age, the quality of water used in boilers was critical; Wood noticed that the water in the Mundaring reservoir was becoming saltier, and he correctly identified the cause as the ringbarking of trees to provide more surface-water yield from the catchment. The subsequent rise in the water-table and the mobilisation of salts stored in the unsaturated zone ultimately resulted in saltier runoff. Although this recognition led to the replacement of the trees in the Mundaring catchment, the expansion of agriculture across

\section{Did know?}

\section{5: Heritage springs and endemic species}

Artesian springs are the natural outlets of the extensive artesian aquifer from which the groundwater of the Great Artesian Basin flows to the surface. The first systematic survey of the basin's springs was by JA Griffiths (1896-98). Today, only 20 of the 107 spring groups identified more than 100 years ago remain active. Lowering of aquifer pressure caused by groundwater extraction from the thousands of bores is thought to be responsible for this decline. The environmental impact is enormous, with the loss of springs leading to the extinction of endemic biota.

Springs can range in size from only a few metres across to large clusters of freshwater pools known as 'supergroups'. Elizabeth Springs, situated approximately $300 \mathrm{~km}$ south-southeast of Mt Isa in western Queensland, forms part of the Springvale supergroup of springs, which that are largely extinct with the exception of this last one (Figure 7.5). The Elizabeth Springs goby is endemic to these waters.

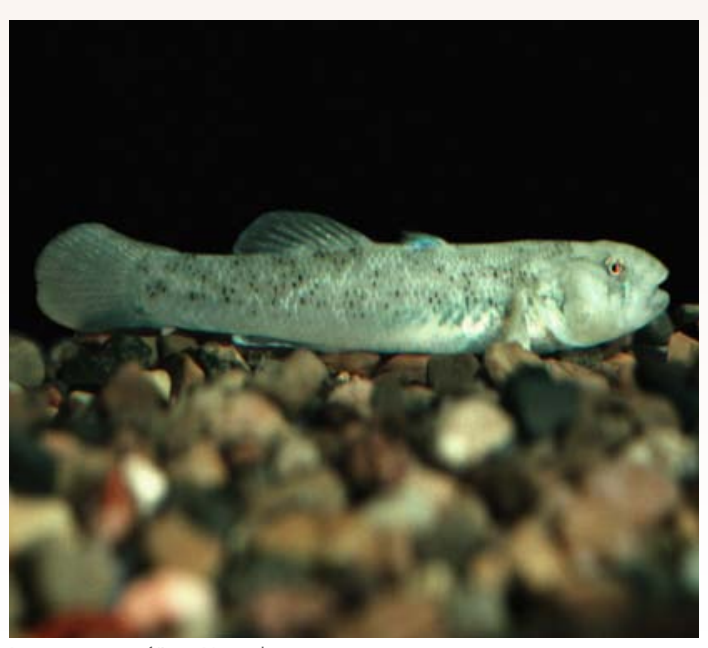




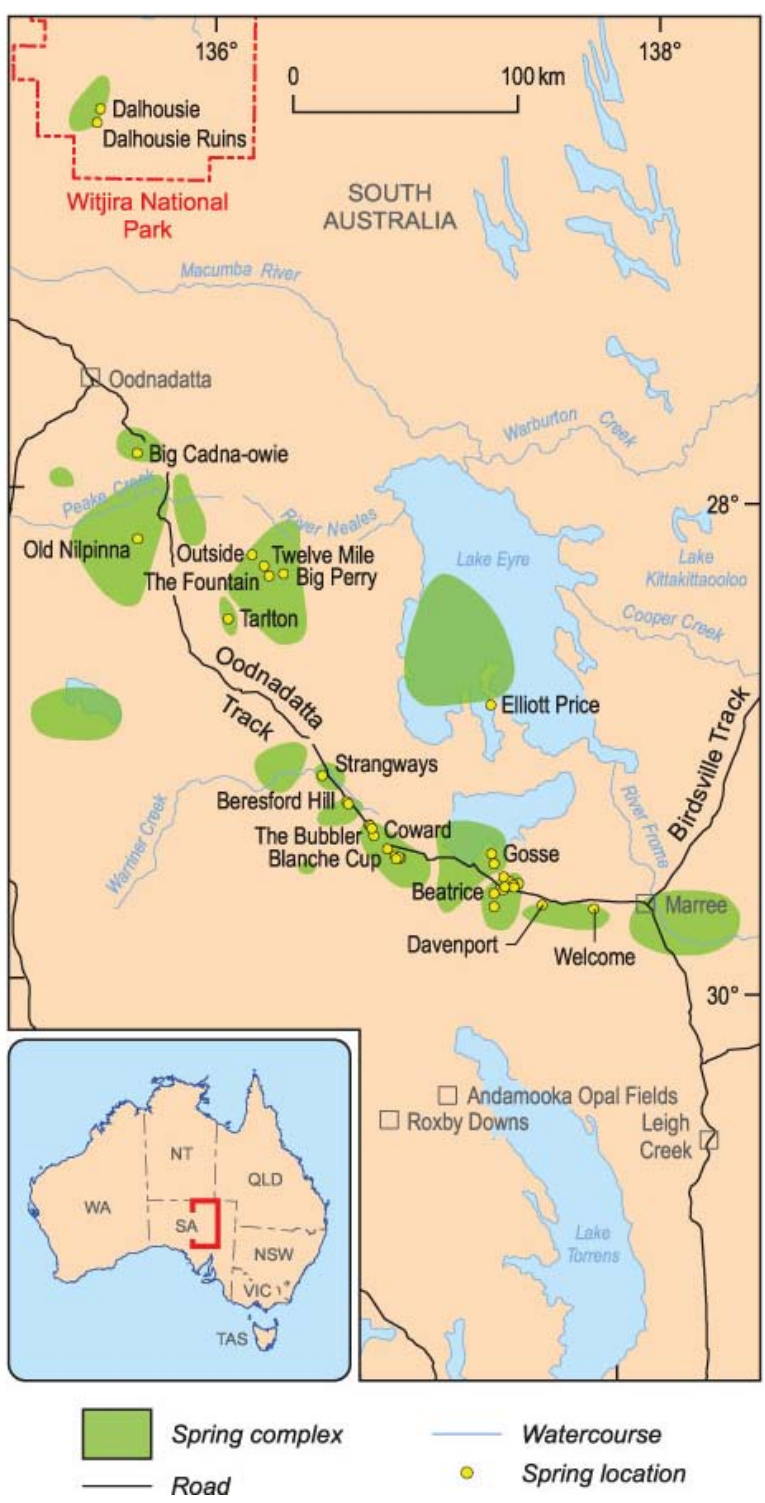

Figure 7.14: Mound springs of south and west Lake Eyre in South Australia. The Oodnadatta Track follows the route taken by the explorer McDouall Stuart, who in 1862 followed the ancient Aboriginal path that linked this arid region's mound springs. One of the largest mound springs is The Bubbler, which formed by groundwater discharge from the Great Artesian Basin. Such wetlands are unique groundwater-dependent ecosystems in an otherwise arid landscape.
Australia has largely ignored the dangers of salinisation (Figure 1.10). In the Western Australian wheatbelt, wells that were once fresh became salty and unusable.

Land and stream salinisation, commonly known as 'salinity', began to be recognised as a serious problem only in the 1960s. The 1990s was the Australian Decade of Landcare, and many farming communities were involved in regenerating the land, to address issues such as salinity. Much effort was directed to reducing groundwater recharge by tree planting, embraced enthusiastically by the younger generation, but not necessarily by their grandfathers who had spent much backbreaking effort on clearing the land in the first place.

Salt is part of the Australian landscape, and there are many sources (Chapter 5). Ocean or 'cyclic' salt is delivered inland with rainfall or as dryfall, as much as $300 \mathrm{~kg} / \mathrm{ha} /$ year near the coast to less than $15 \mathrm{~kg} / \mathrm{ha} /$ year hundreds of kilometres into the interior. Flushing is limited in the extensive areas of old, weathered soils, low rainfall and subdued topography, and salt accumulates over time in the soil and groundwater. Also, a geological history involving the advance and retreat of the sea (Chapter 2) has led to deposition of marine sediments with their (connate) salts, which may eventually become remobilised. Along the coastal margin, ingress of 'marine' salt can occur by intrusion of seawater into aquifers, as well as surface inundation during rare extreme tidal or tsunami events (Chapter 6). Rock weathering also releases 'mineral' salts. 'Aeolian' salt can be imported into a catchment with dust deposited by wind from the arid interior. Windborne sediment and salt deposition can be significant (Chapter 5). A dust storm in December 1987 was estimated to have eroded about $6 \mathrm{Mt}$ of topsoil with subsequent deposition rates of $2 \mathrm{t} / \mathrm{km}^{2} /$ day. On the Southern Alps of New Zealand, the same dust tinged the snow red.

Widespread removal of native vegetation has led to a fundamental change in the water balance within cleared catchments. Soil loss, combined with the removal of deep-rooted water-efficient native vegetation and replacement with European cropping systems, has fundamentally increased groundwater recharge rates. This has been magnified in irrigation areas, where the water balance has been even more dramatically altered. Significant water-table rises and the mobilisation of salts that were stored in the subsurface is manifested in land and water salinisation.

Indeed, national assessments published in 2000 presented a grim picture of the extent of dryland salinity, with $4.7 \mathrm{M}$ ha estimated at risk, projected to rise to $6.4 \mathrm{M}$ ha by 2050 . However, this forecast is now considered to be overly pessimistic, partly because subsequent work has revealed that hydraulic equilibrium has already been reached for certain cleared catchments across Australia. This means that water-table depths and the extent of saline scalds largely vary with trends in rainfall. For example, in upland New South Wales catchments, groundwater levels (and incidence of salt scalds) rose following the transition to a wetter phase after 1947 and declined with the return to relatively dry conditions in 2000 . 


\section{O KEEPING SALT OUT OF THE MURRAY}

\section{(BOX 7.4)}

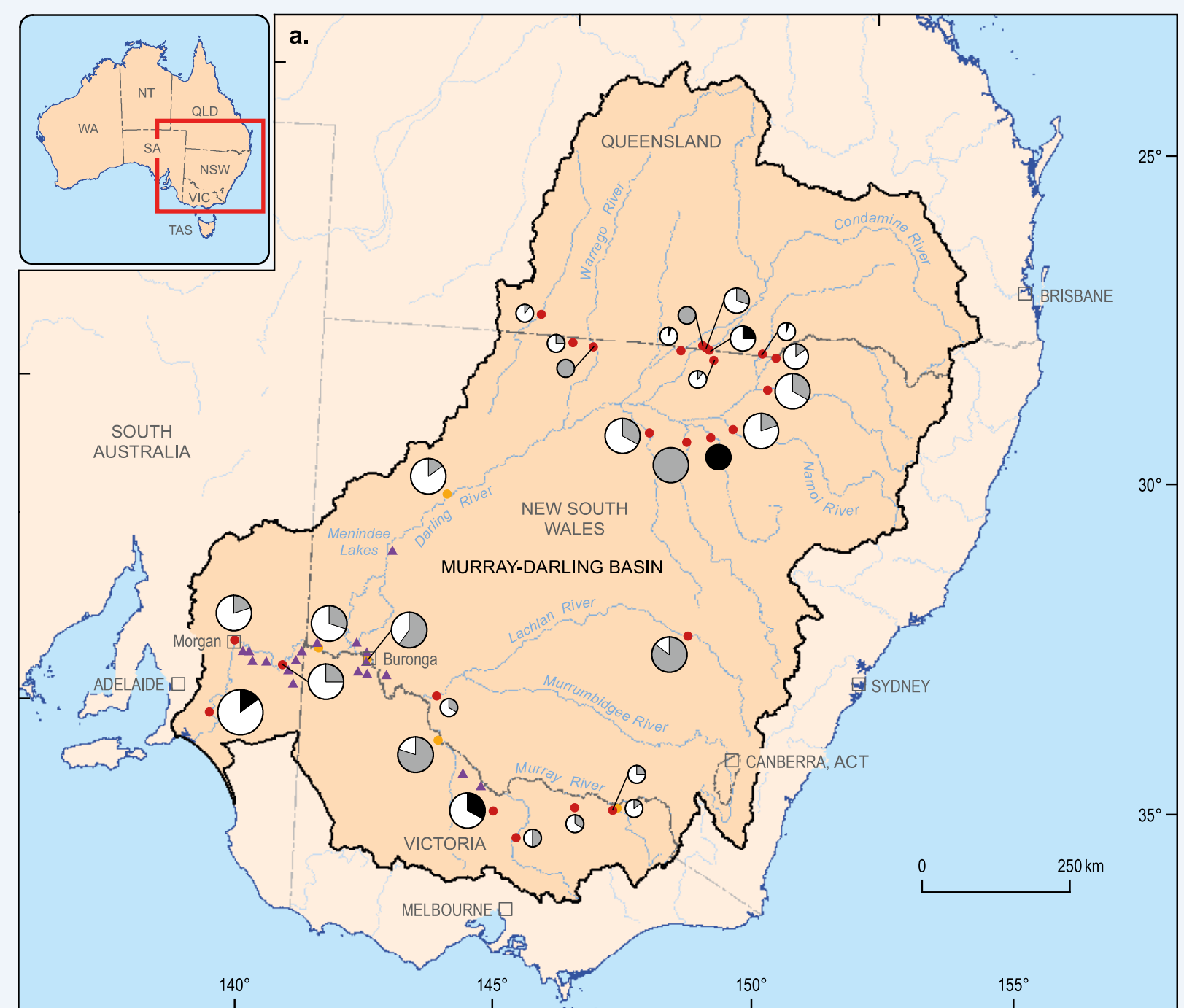

Size of baseline (year 2000 baseline EC)

$\bigcirc^{\bigcirc} \begin{aligned} & 50-200 \\ & 200-400 \\ & 400-600 \\ & 600-1400\end{aligned}$

Figure B7.4a: Baseline river salinity measured in 2008-09 for catchments as part of a coordinated salinity management strategy for the Murray-Darling Basin. Salt interception schemes, (borefields) are a significant engineering solution as part of the basin strategy. (Source: Murray-Darling Basin Authority)

- Salt interception scheme

- Australian Wetlands Australian Wetlands
and River Centre site
\% below baseline
The Murray River drains a semi-arid landscape containing significant stores of salt. In certain reaches, saline groundwater discharges into the river, a process exacerbated by water-table rises caused by enhanced recharge from extensive clearing of native vegetation and irrigation development. In response, various land management and engineering solutions have been implemented, with the goal of maintaining river salinity at the downstream town of Morgan (SA) below $800 \mu \mathrm{S} / \mathrm{cm}$ (electrical conductivity-ECunits) for $95 \%$ of the time (Figure B7.4a).

Salt interception works, involving the large-scale pumping and disposal of saline groundwater away from the river, are a major plank of the strategy. Collectively, these schemes reduce the salt load to the river by about $450000 \mathrm{t} /$ year, by pumping about $55 \mathrm{GL} / y e a r$ of saline groundwater to reduce the hydraulic gradient towards the river. This groundwater is usually piped to an evaporative disposal basin (Figure B7.4b) where crystallised salt can be harvested.

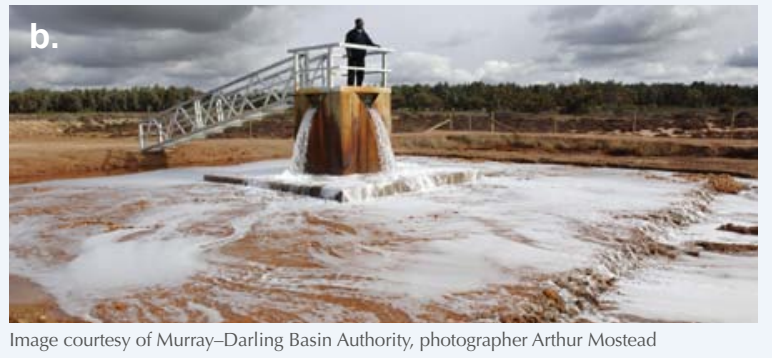

Figure B7.4b: Discharge of saline (ca $45000 \mathrm{EC}$ ) groundwater from the Buronga Salt Interception Scheme at the Mourquong evaporative disposal basin, South Australia. About 23000 t of commercial-grade salt is harvested each year from the disposal basin. (Source: Murray-Darling Basin Authority) 


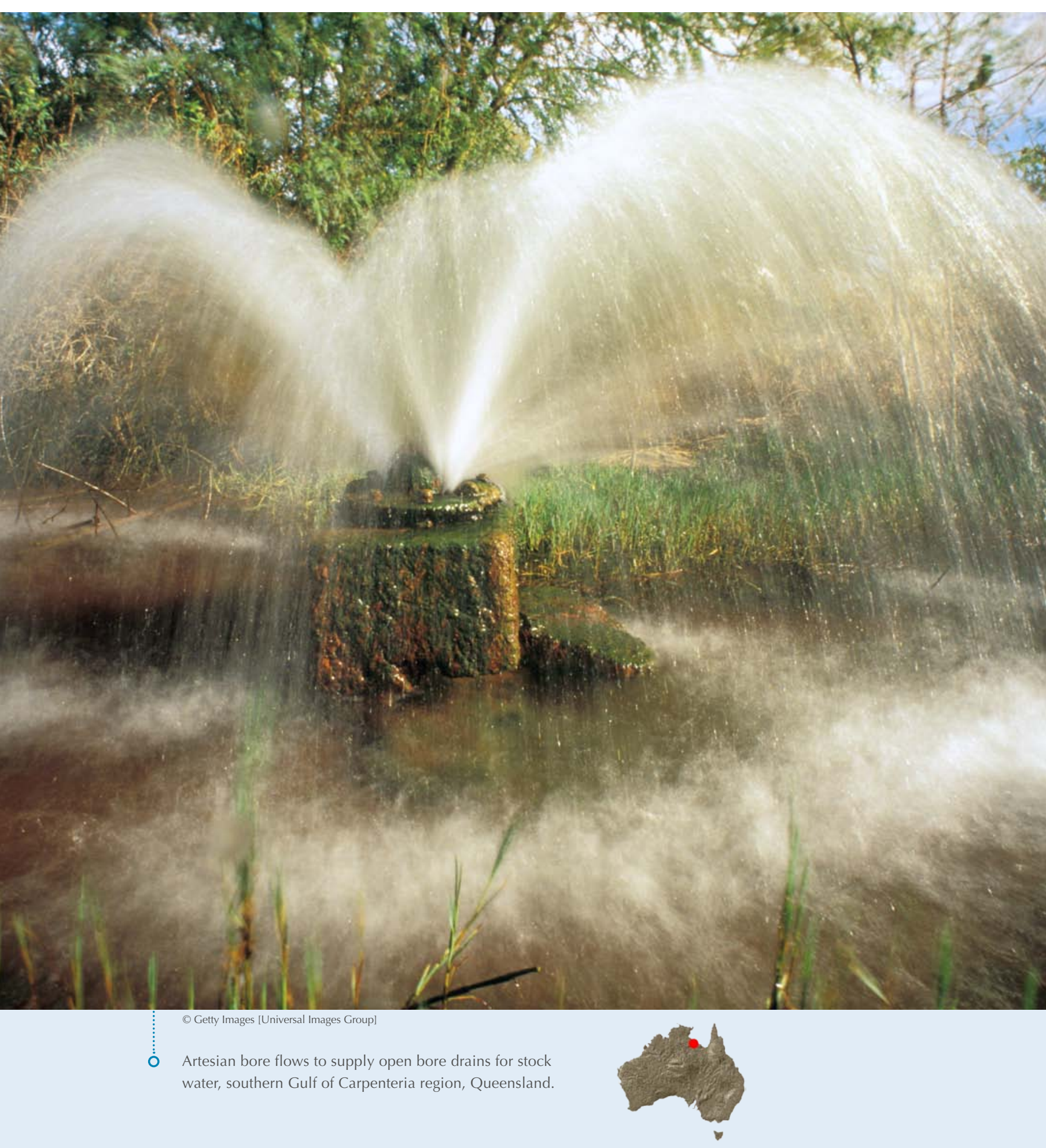

It is important to note that not all land salinisation is groundwater related. 'Transient' salinity is the term coined for the build-up of salt in the soil profile due to dense clay subsoil horizons limiting downward leaching. The near-surface salt store fluctuates with rainfall and evapotranspiration, and is not associated with a shallow water-table. Such subsoil horizons tend to be alkaline, to have high levels of $\mathrm{Na}$ and to be deficient in nutrients, with potential plant toxicities due to elevated boron, carbonate and aluminate. These deficiencies are a significant resource management issue in their own right, estimated to cost the farming economy about \$1.3 B each year (Box 7.4).

\section{Changing land use: a trigger for acid waters}

Salinisation was an unanticipated consequence of clearing of inland catchments. Similarly, the clearing and drainage of coastal catchments has brought about unintended negative impacts (Chapter 6). Floodplain and backswamp drainage works and tidal barrages were established, ostensibly as a flood mitigation measure, but also to 'reclaim' the land for agricultural purposes. However, the negative consequence was not salinisation but the release of acid water or oxygen-depleted 'black' water into waterways and estuaries. Public concern mounted with huge fish kills, particularly after drought-breaking rains. So what was happening?

To answer this, we have to go back to 6.5-8 ka when the rapid mid-Holocene sea-level rise that created the Torres and Bass straits also deposited estuarine clays as palaeovalley infill and thin veneers over coastal sands. This also laid the foundations for acid 
sulfate soils that contain pyrite. These iron sulfides were formed by bacteria combining iron from the organic-rich waterlogged sediments with sulfate in the brackish tidal waters. It has been estimated that there is about $1 \mathrm{Bt}$ of pyrite within these sediments along the Australian coast. When maintained in a natural waterlogged state, the sediments, termed potential acid sulfate soils, are stable. However, activities such as road construction, drainage, cropping, urban development and mining can expose these sediments to air. This triggers oxidation of the pyrite, which in turn generates sulfuric acid, forming an acidified profile of actual acid sulfate soils. This can lead to denuded acid scalds. Following rain, the store of acid can migrate into drains, estuaries and wetlands (Figure 7.15). The acid water can have a $\mathrm{pH}$ less than 2 and dissolves iron $(\mathrm{Fe})$, aluminium $(\mathrm{Al})$ and other metals, resulting in a toxic concoction for aquatic life (Chapter 6). Following a major flood in 1994 , more than $1000 \mathrm{t}$ of sulfuric acid, $450 \mathrm{t}$ of $\mathrm{Al}$ and $300 \mathrm{t}$ of $\mathrm{Fe}$ were released into the lower reach of the Richmond River (northern NSW). Dissolved silica can also initiate algal blooms, and precipitates of $\mathrm{Fe}$ and $\mathrm{Al}$ can smother aquatic plants. Secondary oxidation of $\mathrm{Fe}$ also consumes oxygen, contributing to the 'black' water events.

Understanding the complex interactions between groundwater and surface water is fundamental to managing acid sulfate soils. Backswamp drainage lowers the shallow water-table, exposing the soil pyrite to air and initiating acidification. Rising water-tables can bring the acid products to the land surface. Seepage of acid groundwater occurs when the shallow water-table is higher than the drain water level. Acid export can result, with tidal drawdowns causing low drain levels and a high hydraulic gradient towards the drain. This is exacerbated if the acid sulfate soil has high hydraulic conductivity, mainly due to cracks and macropores caused by soil shrinkage or biological activity.

The economic impact of acid sulfate soils along the coast is significant, considering that this is where most Australians live (Chapters 1 and 6). The cost of works to avoid or prevent acid drainage associated with coastal urban development is estimated to exceed $\$ 100 \mathrm{M}$ every year in Queensland alone. To make things worse, it has recently emerged that acid sulfate soils are not just limited to the coastal zone. Sulfidic muds can be found in inland wetlands, particularly ones associated with long-term inundation and impacted by salinity. Recent droughts have led to these wetlands drying out, initiating sulfide oxidation and acid release. In 2002, the alarm was raised at Bottle Bend Lagoon on the Murray River, when the $\mathrm{pH}$ dropped to less than 3, killing the fish and also the surrounding trees (Figure 7.16).

Acid groundwater containing toxic dissolved metals has also been identified in the Western Australian wheatbelt, particularly in the extensive valley floors. These groundwaters typically have a $\mathrm{pH}$ of 3-4, with the acidity attributed to oxygenated recharge water reacting with shallow Fe-rich groundwater. The latter is thought to have initially formed in topsoil horizons during prior waterlogged conditions, which then percolated downwards to the water-table, leaving behind residual alkalinity in the form of carbonate

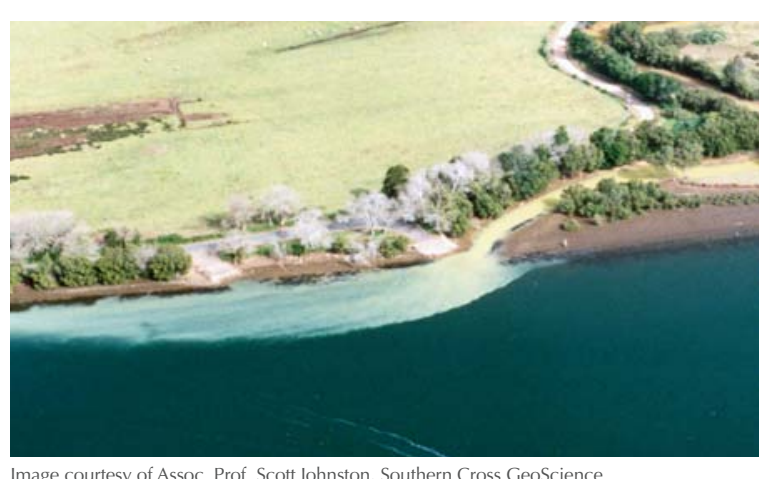

Figure 7.15: Discharge of an acid water plume into the estuary of the Hastings River, mid-north coast of New South Wales. (Source: Johnston et al., 2004)

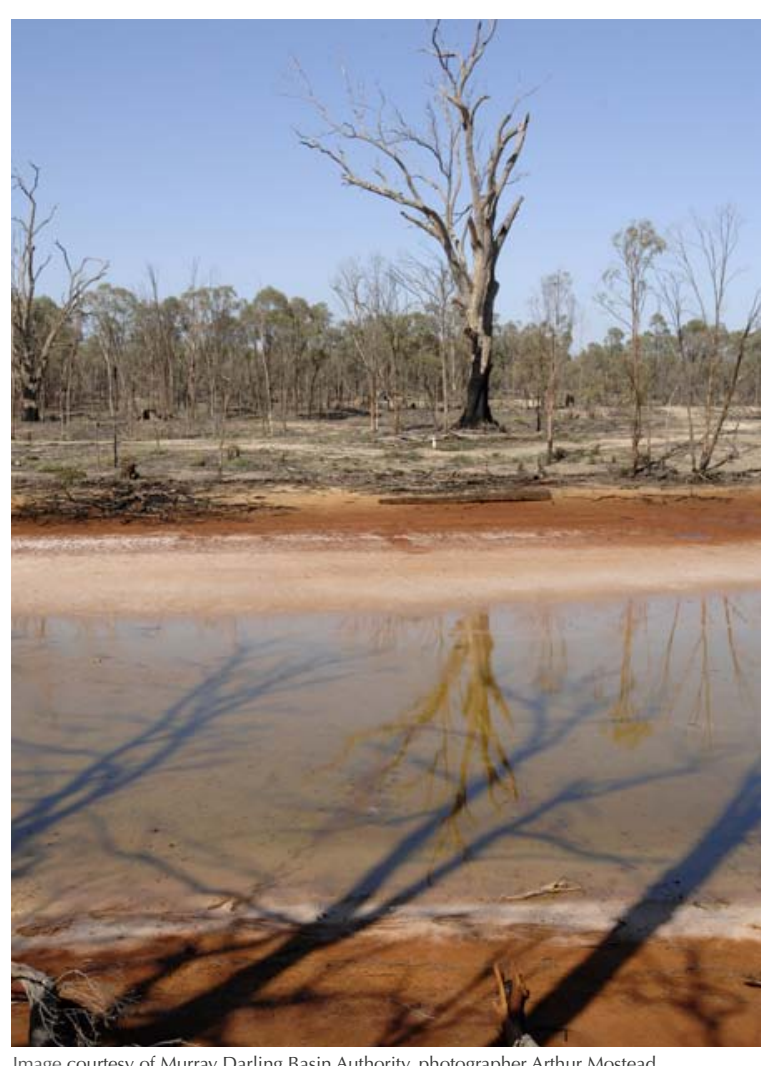

Figure 7.16: Bottle Bend Lagoon, near Mildura, Victoria, on the Murray River, affected by both salinity and acid sulfate soils Salinity has been measured at 140000 electrical conductivity units ( $\mathrm{EC}$ ), and $\mathrm{pH}$ has been measured at $<3$. For comparison, the salinity of seawater is ca $55000 \mathrm{EC}$. 


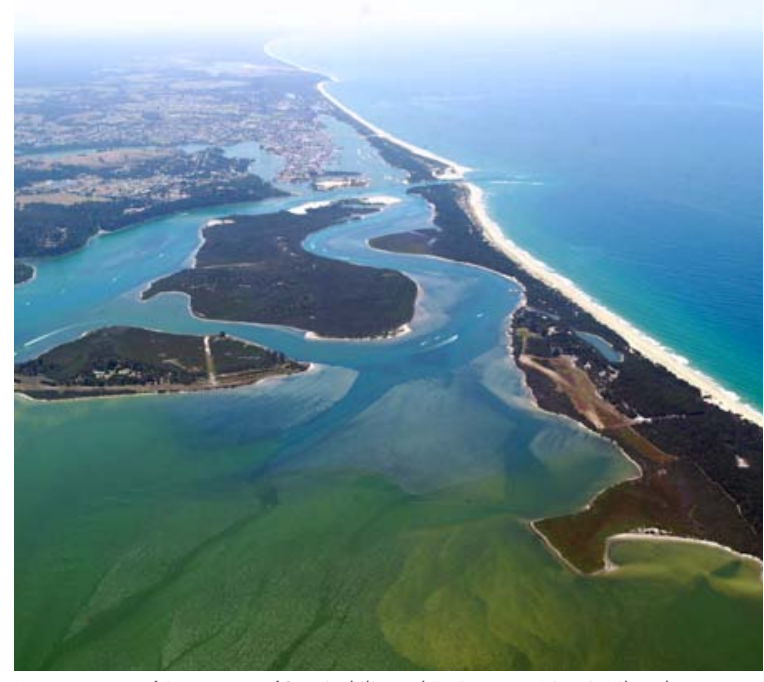

Image courtesy of De
Richard Teychenne

Figure 7.17: Bloom of the cyanobacterium (blue-green alga) Synechococcus in the Gippsland Lakes, Victoria, in January 2008. Algal densities were above water-quality trigger levels for about five months. Groundwater discharge as well as surface runoff can transport nutrients into waterways to provide conditions for the triggering of toxic algal blooms. (Source: Department of Sustainability and Environment, Victoria) soil nodules. As the groundwater still contains dissolved $\mathrm{Fe}$, it has the potential to become even more acidic if exposed to the air. There is concern that the shallow groundwater pumping and the network of over $5000 \mathrm{~km}$ of deep drains used to control shallow saline groundwater may also release acid and toxic metals to aquatic ecosystems. The $\mathrm{Al}, \mathrm{Fe}$ and $\mathrm{Mn}$ levels in the acid groundwaters can exceed $10 \mathrm{mg} / \mathrm{L}$, with high concentrations (sometimes $>1 \mathrm{mg} / \mathrm{L}$ ) of lead, copper, nickel, zinc and uranium.

\section{Change and development: a legacy of nutrients and contaminants}

A legacy of waste disposal practices in Australia was uncovered in the 1970s when attention was directed to point-source pollution, mainly from industry, but also from municipal waste disposal and leaking petrol stations. Shallow sands such as the Perth coastal plain and the Botany Sands in Sydney were the focuses of investigation. For a long time before regulation, waste products that could soak away at the back of a business were an externality: 'out of sight, out of mind'. The problem for the community is that groundwater has a 'long memory' (Did you know? 7.6), and consequently some 600 likely pollution point sources were identified in the Perth area alone.

Groundwater can also be a vector for the transport of dissolved nutrients into waterways. The discharge of groundwater with elevated levels of nitrogen and phosphorus brought about by agricultural or urban activities can cause eutrophication in rivers and wetlands. This is the excessive growth of aquatic plants that prevents the penetration of sunlight, and upon decay depletes dissolved oxygen levels (Figure 7.17). Cyanobacteria (blue-green algae) blooms kill fish and can also be toxic to humans and livestock. In 1991, such an outbreak occurred over a $1000 \mathrm{~km}$ reach of the Darling River, resulting in the New South Wales Government declaring a state of emergency.

\section{Surface changes: subsidence and lowering of the land}

Land subsidence is the lowering of the land surface due to changes that are taking place underground, including the overextraction of groundwater. This subsidence can be reversible in confined aquifers that are subject to elastic compression or expansion as groundwater pressure changes, but can be irreversible where fine-grained sediments such as clay or peat compact on dewatering.

Confined aquifers hold water in elastic storage; hence withdrawal of groundwater leads to a compaction of the aquifer and to subsidence at the land surface. Recovery of water levels or the addition of water can similarly lead to a rise in the land surface. Generally, this is too small to be measured by conventional means and has no significant impacts; however, one of Geoscience Australia's high-resolution GPS stations in the Perth Basin is ideally situated to measure these changes. The GPS station at the Hillarys Marina tide gauge in Perth's northern coastal suburbs is almost coincident with the centre of the drawdown cone in the Jurassic Yarragadee Aquifer, one of two confined aquifers used for Perth's water supply. Since the mid 1990s, extraction from the Yarragadee has substantially increased with population growth, resulting in a 
maximum drawdown of some $50 \mathrm{~m}$ at Hillarys, together with around $10 \mathrm{~m}$ of drawdown in the overlying Cretaceous Leederville Aquifer. The Hillarys GPS station showed a $50 \mathrm{~mm}$ subsidence of the land surface between 1997 and 2011, coincident with these potentiometric head changes (Figure 7.18).

The best-known Australian case of land subsidence associated with groundwater dewatering is that of the Latrobe Valley in the Gippsland Basin. Here, mining at Morwell has removed some $1500 \mathrm{Mt}$ of coal for Victorian power stations and $850 \mathrm{GL}$ of groundwater for mine stability. Around the mining operations, this has led to groundwater levels dropping by up to $125 \mathrm{~m}$ and the land subsiding by more than $2 \mathrm{~m}$ in places. There are concerns that land subsidence is a much broader issue for the Latrobe Aquifer, which is extensive, and is used for irrigation and industry, as well as being dewatered offshore with oil and gas production in Bass Strait (Chapter 4). Monitoring along the Gippsland coastline shows a consistent decline in groundwater levels of about $1 \mathrm{~m} /$ year. Modelling has inferred that subsidence in the most affected coastal area would be in the order of $0.5-1.2 \mathrm{~m}$ by 2056 .

\section{A groundwater future for the driest inhabited continent}

We have seen a rapid expansion in the use of groundwater resources in Australia over the past 40 years. This 'boom' in groundwater development, particularly of shallow alluvial systems in floodplain and coastal landscapes, has been driven by government limits placed on surface-water licences, combined with rainfall declines and prolonged droughts, particularly in southern and western Australia. During this period, scientific investigation and monitoring have just not kept pace with the development. We are also only just starting to recognise the connectivity and influence that groundwater can have. A positive influence is providing for river baseflow and ecosystem health. A negative influence is the mobilisation of salts, acid and contaminants. Sustainable management of Australia's groundwater systems is therefore critical to protecting our unique ecosystems, heritage and cultural values, and long-term socioeconomic advancement.

Australia also has a global role to play in helping to feed the burgeoning world population, particularly amid declining land and water resources. Despite all this, there are significant data and knowledge gaps in the understanding of how our groundwater systems actually work and how they interact with the rest of Australia's landscape.

So what are the issues and technologies that are on the horizon that will influence how we use and manage our groundwater systems in the future?

\section{Groundwater and a changing climate}

The vagaries of the Australian climate have long been recognised by farmers and scientists alike. However, it has really only been over the past few decades that the impacts of longer term climate trends have been realised. This was bought home in the southwest of Western Australia, with the mean

\section{Did knouw?}

\section{6: Fremantle's 'lost' water}

As in the case of Darlinghurst, gaols had a ready supply of labour to dig wells. Between 1888 and 1894, inside the gaol at Fremantle, the port city in Western Australia, wells were sunk with connecting tunnels dug along the water-table in the underlying Quaternary coastal limestone. This network serviced Fremantle's water supply, but the addition of two more steam engines led to overpumping and a consequent increase in salinity.

In 1910, the gaol and Fremantle were connected to the metropolitan water supply scheme, and knowledge of the tunnels was lost. In 1989, a bore in the prison began pumping oily water, and analysis of the oil traced it to a nearby fuel pipeline supplying ships in the port. It was found that fuel oil had leaked adjacent to the prison and accumulated in the rediscovered tunnels.

The contamination has now been remediated and, as the gaol is not used as a prison any more, visitors can inspect the tunnels by boat.

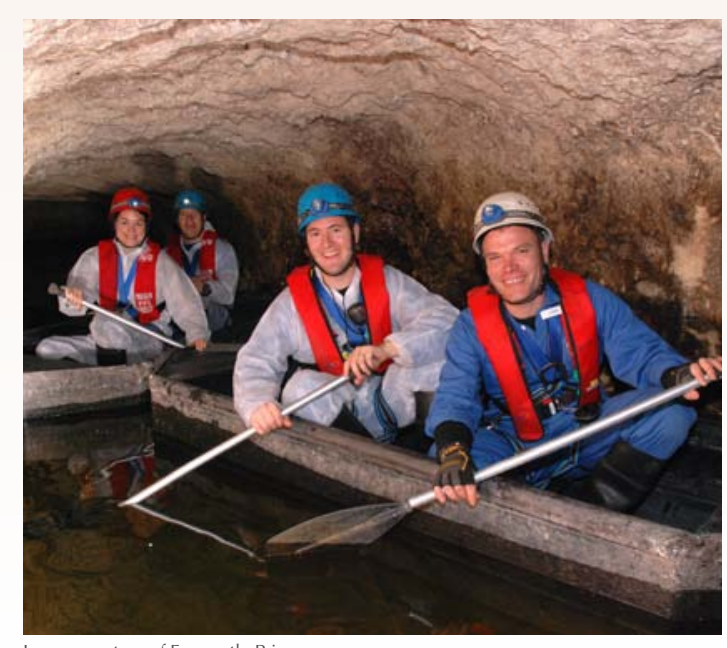



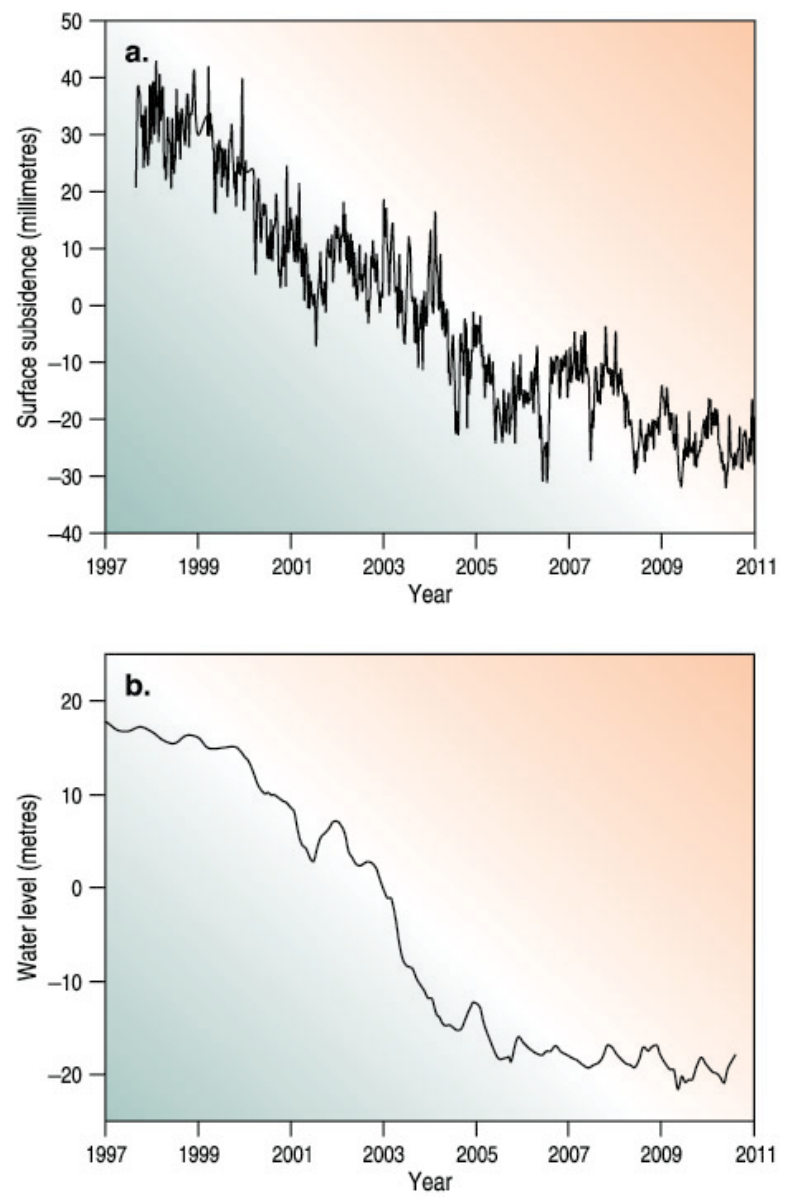

Figure 7.18: (a) Land subsidence recorded by high-resolution GPS associated with (b) declines in groundwater levels due to extraction from the confined Yarragadee and Leederville aquifers, Hillarys Marina, Perth, Western Australia. (Source: Department of Water, Western Australia; Geoscience Australia) annual rainfall decline since 1975 (Figure 7.9). This, and the water crisis in the Murray-Darling Basin, spurred (among other Australian research) a series of CSIRO Sustainable Yield projects involving assessment of regional water resources in the context of future climate change.

The analysis is constrained by the current high level of uncertainty embedded in the global warming projections and the sensitivity of the global climate to responding to greenhouse gases. Some conclusions regarding groundwater in Australia are as follows:

- In the Murray-Darling Basin, the climate change impact on groundwater levels through decreased rainfall recharge was considered minor in comparison with the impact from current and future predicted growth in groundwater use related to population growth.

- In northern Australia, rainfall is highly seasonal, and modelling suggests that the nature of the rainfall (such as duration and intensity) is critical to defining recharge outcomes. A lower recharge may not necessarily be the result of a lowering of total rainfall.

- In southwest Western Australia, the impact of a future hotter and drier climate on groundwater levels will vary, depending on catchment factors such as vegetation cover, soils, water-table depth and groundwater extraction. Groundwater systems in the sandy coastal plain where native vegetation has been cleared are anticipated to be fairly resilient to all but extreme climate change. This is because reduced drainage discharge and evapotranspiration losses will largely offset reduced recharge.
- In Tasmania, the impact of climate change on groundwater levels is anticipated to be very minor.

These assessments highlight the complexity of understanding the relationship between rainfall and recharge. They also suggest that groundwater systems are more resilient to climate change than surface water, so these resources will likely take on an even larger role in providing water security into the future (Chapter 11).

\section{'Water banking' options for managed aquifer recharge}

Dams have been the primary solution to the problem of providing water security in Australia. In the Murray-Darling Basin, public-managed reservoirs have a total capacity of about $35 \mathrm{~km}^{3}$, whereas the average basin runoff is $21 \mathrm{~km}^{3} /$ year. However, evaporative losses can be huge, particularly from storages in the semi-arid interior. The Menindee Lakes in western New South Wales have been engineered to retain floodwater from the Darling River. The maximum capacity of these lakes is about $2000 \mathrm{GL}$, but on average more than 20\% (430 GL) is lost through evaporation each year. To put this into context, this annual loss represents more than $10 \%$ of the $3000-4000 \mathrm{GL} /$ year of water savings proposed under the guide to the Murray-Darling Basin Plan.

Storing water underground in aquifers is one way of beating evaporation. Managed aquifer recharge is the term used for a portfolio of approaches to replenish aquifers purposefully for subsequent recovery or environmental benefit (Figure 7.19). The application of managed aquifer recharge 
is in its infancy in Australia, contributing about $7 \mathrm{GL} /$ year to urban water supplies. Assessments undertaken for Perth, Adelaide and Melbourne suggest that this could be scaled up to at least $200 \mathrm{GL} /$ year in these three cities alone. Perth already has a passive system where drainage sumps, and sometimes wetlands, in the dunal depressions receive road runoff and allow infiltration into the shallow aquifer. Runoff from roofs and paved driveways also infiltrates through soak wells in the sandy soil. The recharge from winter storms is then extracted during summer from more than 100000 garden bores. In water-short Adelaide, urban stormwater is being seen as a resource to collect and recharge into both fractured rock and sedimentary aquifers, to be recovered during peak summer demand. In many Australian cities, the annual volume of urban stormwater runoff can be more than the water being reticulated. However, less than $3 \%$ of urban stormwater runoff is currently being harvested, with water storage being a major impediment.

Managed aquifer recharge operations in Australia were actually pioneered not in the cities but in irrigation areas. Infiltration pits and sand dams built from the 1960s in the Burdekin Delta now recharge up to $45 \mathrm{GL} /$ year to offset groundwater pumping and prevent seawater intrusion (Figure 7.20). Also in Queensland, weirs were built across the Callide and Lockyer creeks with the express purpose of replenishing the shallow alluvial aquifers. In the Angus-Bremer irrigation area of South Australia, drawdowns and rising groundwater salinity in the exploited aquifer were mitigated through injection of surface water.

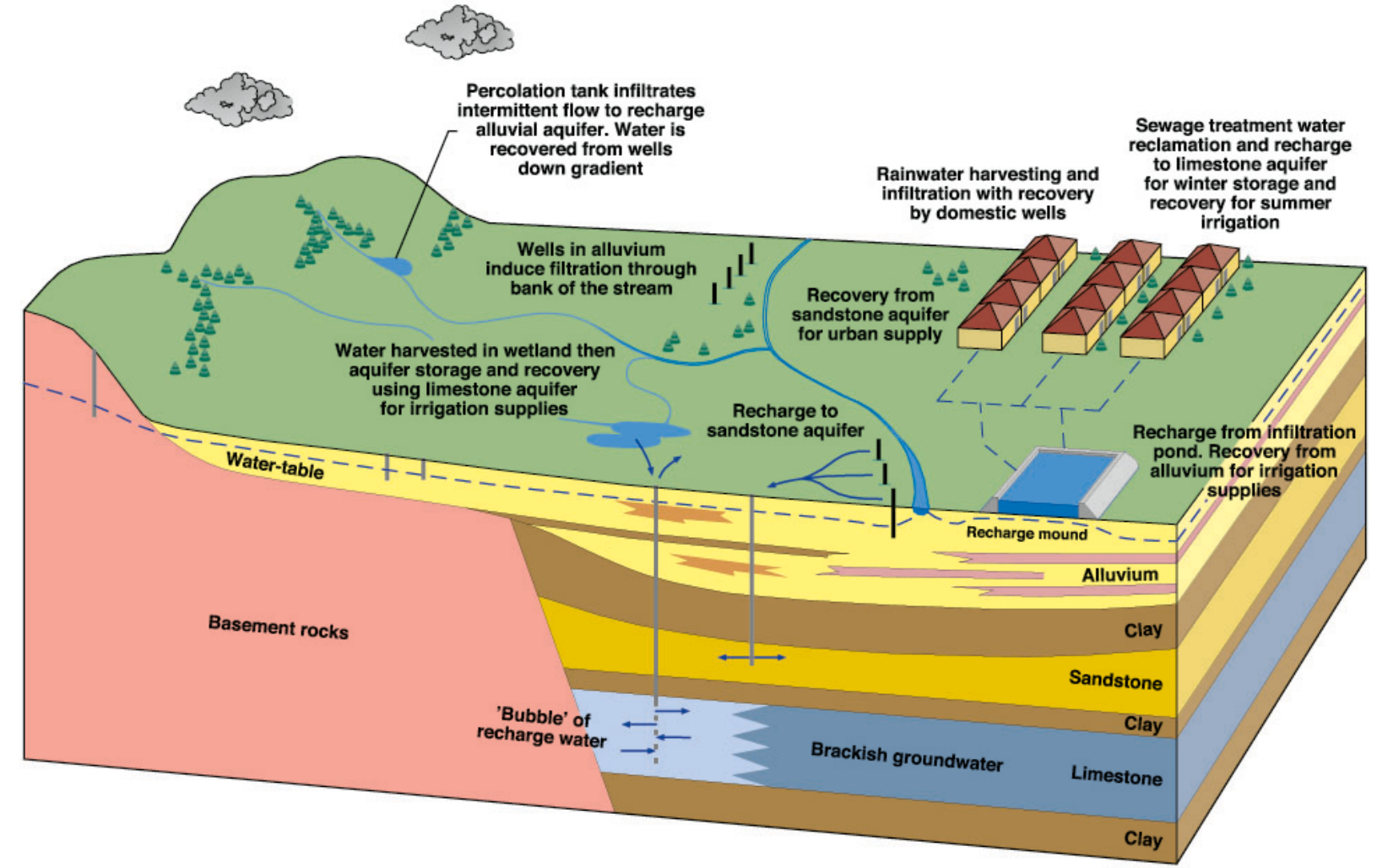

The full potential of actively using aquifers as underground water storages for urban, rural and remote water use across Australia has yet to be realised.

\section{Large sedimentary basins: a groundwater El Dorado?}

In May 2000, the CEO of Anaconda Mining called a press conference to reveal details of a plan to pipe newly discovered groundwater in the Officer Basin (Figure 7.1) to Kalgoorlie and Perth. This followed initial drilling to locate a contingency supply of process water for the Murrin Murrin nickel laterite operation near Laverton in the Eastern Goldfields (WA). An incredulous press
Figure 7.19: Some examples of managed aquifer recharge well injection, infiltration basins and percolation tanks. (Source: Dillon et al., 2009)

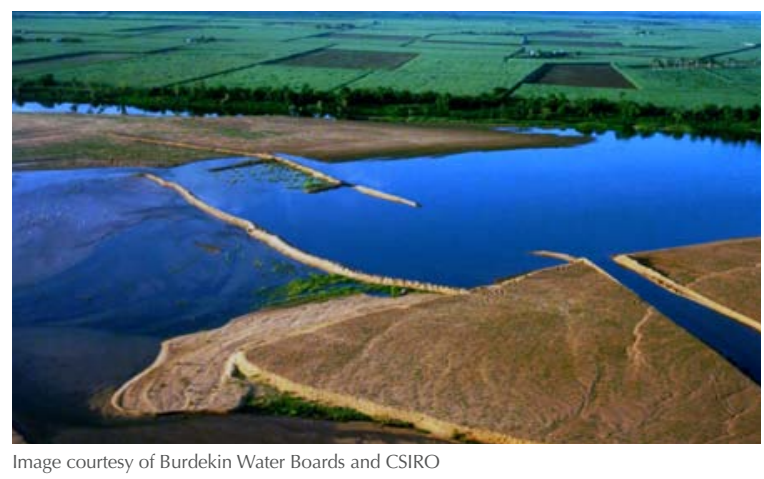

Figure 7.20: Managed aquifer recharge operations in the Burdekin Delta, Queensland, using sand dams to facilitate river infiltration. (Source: Dillon et al., 2009) approaches to enhanced aquifer storage and recovery, including 
ran stories on the 'inland sea' that could supply Perth for 4000 years (cf. Box 1.5). One headline claimed 'mining company trips over basin the size of England'. In fact, the Officer Basin had been mapped and described previously, with the main aquifers being the $400 \mathrm{~m}$ thick sequences of the Permian Paterson Formation and Devonian Lennis Sandstone. However, its groundwater potential was largely unknown outside a few unpublished government reports. The Anaconda drilling subsequently revealed that the groundwater was, as predicted, brackish. The potential of the Officer Basin, however, is still largely unknown, and the existence of significant fresh groundwater cannot be discounted.

To the north, the Canning Basin underlying the Great Sandy Desert is Australia's second largest artesian basin (Figure 7.1). The basin covers $530000 \mathrm{~km}^{2}$, about the size of mainland France, and contains extensive Permian, Jurassic and Cretaceous sandstone aquifers. This basin certainly does contain large volumes of low-salinity water, which is only used along the coast. Carbon dating of the groundwater in the West Canning Basin suggests that the groundwater is replenished regularly, and is not a fossil remnant of a previous wetter period (Chapter 5).

These basins are commonly viewed as large untapped groundwater resources. However, dreams of piping the groundwater to Perth for urban use have been thwarted by the tyranny of distance, as preliminary costings confirm that the energy, greenhouse emissions and overall supply cost would be significantly greater than for seawater desalination. The other factor is the sustainability of extraction, as recharge rates are largely unknown. Groundwater development of these large sedimentary basins in the future is more likely to service local or regional needs.

We have seen earlier that the Great Artesian Basin is Australia's largest groundwater resource. The Murray-Darling Basin, comprising the southern part of this large basin, was so stressed by the prolonged droughts of the 1990s-2000s that the impacts could be measured from space (Box 7.5).

\section{Untapped resources: brackish and saline aquifers}

The Australian map of groundwater salinity (Figure 7.21) shows the extent to which only brackish or saline groundwater is available for large tracts of the continent. This is particularly the case for the southern and inland areas, where surface water availability can also be severely limited. Here, a flat, ancient landscape and the lack of flushing rains and rivers have conspired in the prolonged accumulation of salt (Chapter 5). However, the advancement of desalination technologies may yet unlock this groundwater resource.

Although Australia is the driest inhabited continent, only about $1 \%$ of the global installed desalination capacity is found here. The bulk of desalination in Australia focuses on using seawater for our coastal capitals; such capacity is projected to increase 10-fold from $45 \mathrm{GL} /$ year in 2006 to 450 GL/year by 2013 (Figure 7.22). Desalination of local brackish groundwater is already occurring for key remote communities in the arid interior,

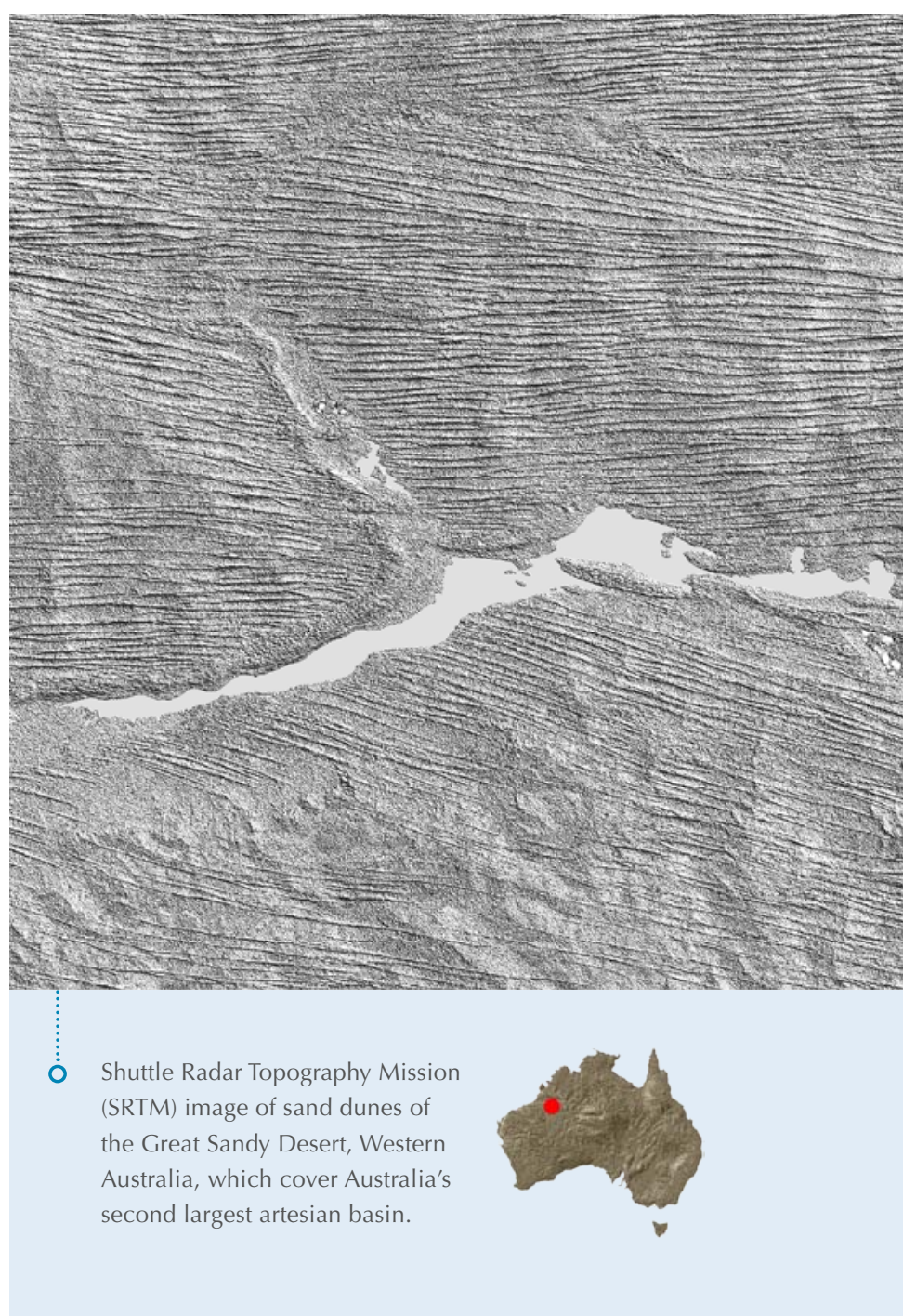




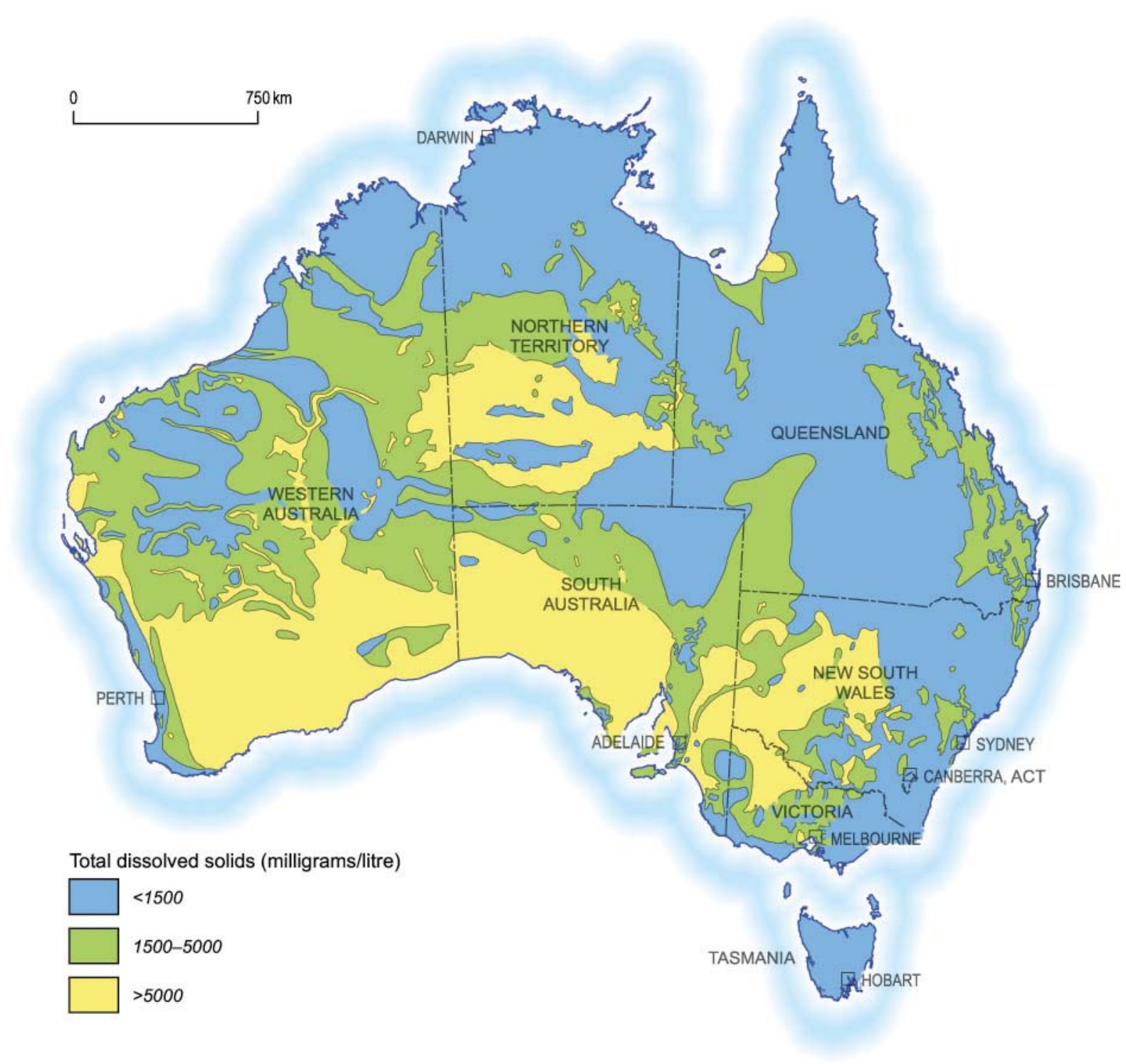

Figure 7.21: Groundwater salinity within the main aquifers across Australia. (Source: Lau et al., 1987) such as Yulara, near Uluru. The lowering of capital, operating, maintenance and energy costs as desalination technologies advance could provide impetus for improved water supply and economic development across large areas of Australia. Over recent decades, improvements in pumps have halved the energy requirements of reverse osmosis plants, with new energy-recovery equipment halving this again. The linking of desalination with renewable energy sources such as solar and geothermal is also showing promise (Chapter 10). It is important to note that for much of Australia the available groundwater is brackish (say, $<5000 \mathrm{mg} / \mathrm{L}$ ) rather than of ocean salinities (>30 $000 \mathrm{mg} / \mathrm{L})$. This is important because the energy requirements for reverse osmosis of brackish water $\left(0.7-1 \mathrm{kWh} / \mathrm{m}^{3}\right)$ are significantly less than for oceanic equivalents $\left(3-3.7 \mathrm{kWh} / \mathrm{m}^{3}\right)$. Much of the desalination research agenda, such as forward osmosis techniques, new-generation membranes and nanotechnologies, aims to reduce the current seawater energy benchmark of $3.5 \mathrm{kWh} / \mathrm{m}^{3}$ to the theoretical minimum of $0.8 \mathrm{kWh} / \mathrm{m}^{3}$.

\section{Groundwater and new energies}

The picture many people have of artesian water is the steam coming off. Artesian water from deep confined aquifers is by its nature relatively hot, depending on the aquifer depth and geothermal gradient. Typical geothermal gradients in sedimentary basins range from $2^{\circ} \mathrm{C} / 100 \mathrm{~m}$ in sandstone to $5^{\circ} \mathrm{C} / 100 \mathrm{~m}$ in shales, so that groundwater temperatures commonly range from $30^{\circ} \mathrm{C}$ to $70^{\circ} \mathrm{C}$. Local extremely high gradients have been measured-for instance, 
$1^{\circ} \mathrm{C} / 5 \mathrm{~m}$ across brown coal seams in the Morwell open cut in Victoria. This raises the potential of using the geothermal energy captured within hot sedimentary aquifers (Chapter 10).

In the Great Artesian Basin, hot bore water, up to $100^{\circ} \mathrm{C}$, has historically been discharged into bore drains to allow it to cool sufficiently for stock to drink. Cooling towers equipped with electric fans are also used, resulting in the irony of using fossil-fuel electric power to remove the thermal energy. There are examples across the basin of the direct use of the hot bore water, typically for swimming pools and therapeutic spas (Box 7.3). There are also examples of using open-loop groundwater-source heat pumps to generate electricity; examples of these small Rankine cycle plants have operated successfully in Mulka (SA) and Birdsville (Qld) (Figure 7.23). At the Perth zoo, the bore drilled into the Perth Basin in 1905 was reputedly used to heat the reptile house. It was only in the 1990s that hot Perth Basin groundwater began to be used for heating swimming pools. The North Perth Basin is also an exploration target for hot geothermal groundwater suitable for electricity generation. The hunt for renewable carbon-neutral energy sources has led to interest in the geothermal resource potential of hot sedimentary aquifers and fractured rocks across Australia (Chapter 10).

One aspect of the future exploitation of energy resources in Australia is the potential impact on groundwater resources. This is coming to the fore with the rapid development of coal-seam gas reserves, notably from the Jurassic Walloon Coal Measures of the Bowen and Surat basins (Qld)

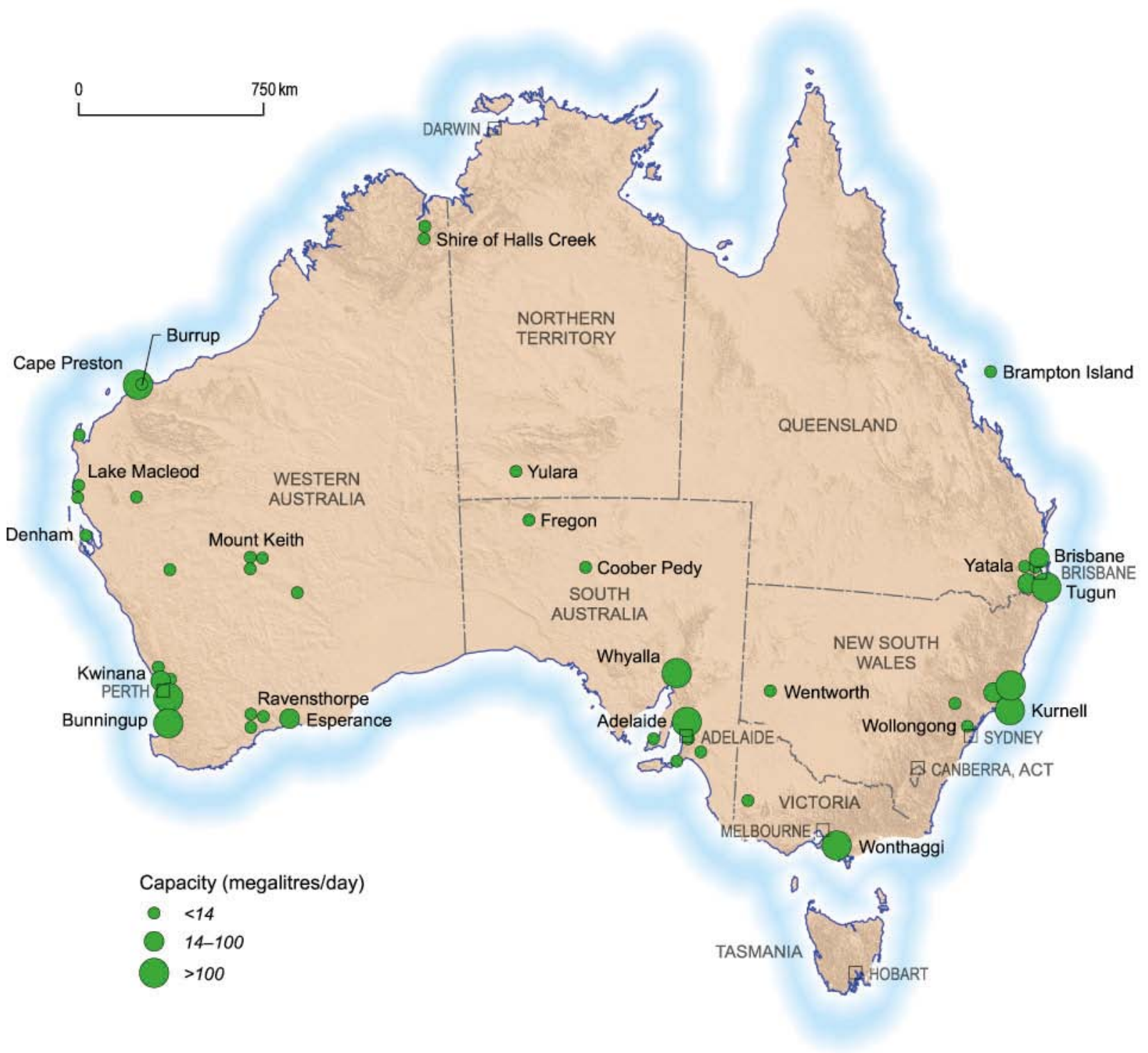

Figure 7.22: Outlook to the year 2013 for desalination sites across Australia. This shows the significant investment in seawater desalination to secure water supply for coastal capital cities, as well as smaller scale operations using brackish groundwater to support remote communities and mines. (Source: Hoang et al., 2009) 


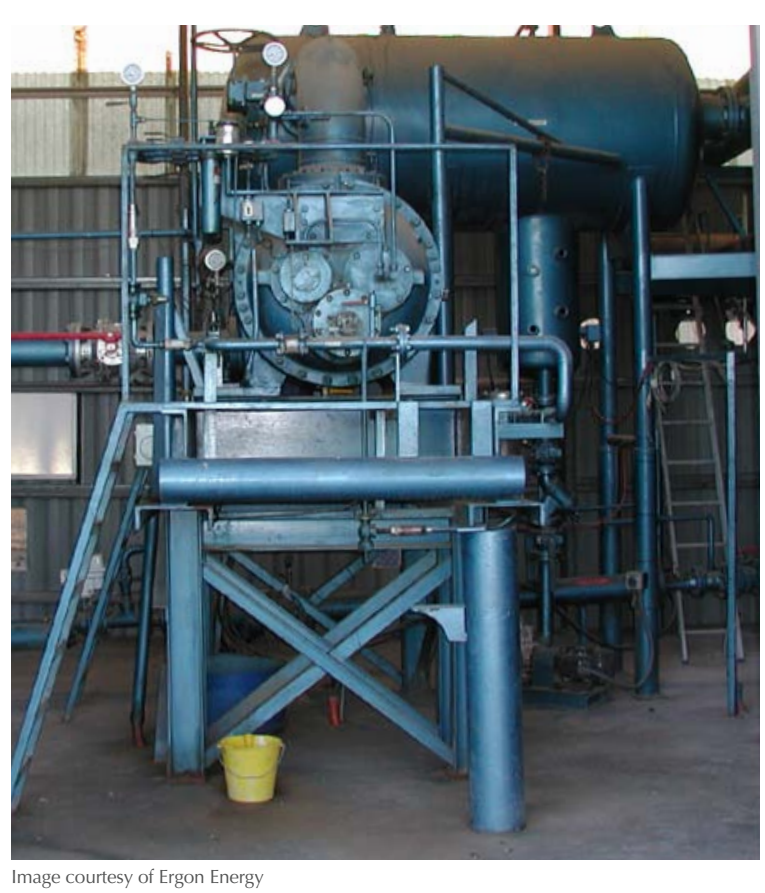

Figure 7.23: At Birdsville in western Queensland, an organic Rankine cycle heat exchanger is used to produce electricity from $98^{\circ} \mathrm{C}$ groundwater from the Great Artesian Basin. The groundwater is supplied at a rate of $27 \mathrm{~L} / \mathrm{s}$ from a $1280 \mathrm{~m}$ deep bore, and the plant has a net output of $80 \mathrm{~kW}$ or about $30 \%$ of the town's power. (Source: Primary Industries and Resources South Australia)
(Chapter 9). The extraction process involves wells drilled into the coal seam to initially extract groundwater to depressurise the seam so that the gas is desorbed and released. Of concern is the appropriate disposal, reuse or reinjection of the coal-seam water, as well as the potential for leakage from the adjacent Great Artesian Basin and overlying alluvial aquifers (Chapter 11).

\section{A geoscience systems approach to future hydrogeology}

By its very nature, an understanding of groundwater systems needs a multidisciplinary systems-based approach, requiring a cohort of geologists, hydrologists, ecologists, modellers, engineers, social scientists and economists, among others. At the core, however, lies the need for a geological understanding of how aquifers and aquitards work.

Geoscience Australia's Broken Hill Managed Aquifer Recharge (BHMAR) project can be used as a case study to highlight the importance of the need for a geoscience foundation to groundwater studies. This project was tasked to discover and evaluate groundwater resource and managed aquifer recharge targets in a data-poor region of the Darling River floodplain in western New South Wales. As part of an initiative funded by the Australian Government Department of Sustainability, Environment, Water, Population and Communities, the overarching objective was to investigate options for enhancing the efficiency of the Menindee Lakes Scheme, a series of large, shallow, water storages in a semi-arid landscape. The project found that, by integrating the full range of geoscientific tools, datasets and skillsets, it was possible to uncover more effectively the extent, distribution and nature of good-quality groundwater resources and aquifer storage.

A regional helicopter-based electromagnetic survey mapped fresh groundwater associated with river leakage in unconsolidated sands and gravels, as well as mapping the clay aquitards that are important as seals in managed aquifer recharge borefields (Figure 7.24a). The airborne electromagnetic data provided the 3D framework of the region in terms of conductivity, which relates closely to salinity. A series of monitoring bores were constructed during an extensive sonic drilling program (Figure $7.24 \mathrm{~b}$ ). The bores provided a $1 \mathrm{D}$ sample of the aquifer's geometry and characteristics, while the airborne electromagnetic data provided the spatial context to map out and interpolate, in $3 \mathrm{D}$, the aquifer's geometry across the region.

The excellent core recovery from the bores enabled detailed sediment and pore fluid analysis, including grain-size distribution, various $\mathrm{X}$-ray determinations (XRD/XRF), moisture content and fluid salinity (Figure 7.24c). These data on the vertical hydrogeological profile were supplemented by downhole geophysical logging, including gamma, conductivity and nuclear magnetic resonance of the project bores (Figure 7.24d). These rock property data were used in the processing of the airborne electromagnetic data, ensuring confidence in what the remote-sensed signal was measuring. 
Extensive sampling and chemical analysis of the groundwater, as well as of the rivers, lakes and rainfall, were evaluated from a water quality perspective, and also provided an understanding of key hydrological processes, such as river leakage, hydraulic connections between aquifers and potential water-rock interactions during managed aquifer recharge operations.

An airborne LiDAR survey was used to generate a high-resolution digital elevation model (DEM) of the region (see also Chapter 5). This dataset revolutionised geomorphological understanding. For example, it was used to derive the flood inundation history, leading to an improved knowledge of the recharge dynamics of the system. The LiDAR survey surface DEM map was supported by more detailed bathymetric surveys of the bed of the Darling River (Figure 7.24e). Together, these high-resolution models and maps highlighted the localised nature of river leakage. The LiDAR survey also helped to determine the geomorphological and stratigraphic framework of the region. The age of the sediments was determined by biostratigraphic dating using palynology (spores and pollen: Chapter 3). The landscape age was determined by optically stimulated luminescence techniques.

An understanding of the geological history and depositional environments can in turn be used in the interpretation of the geometry and hydraulic properties of key aquifers and aquitards. Routine pump testing of project bores was used to derive estimates of aquifer hydraulic properties in target areas (Figure 7.24d).

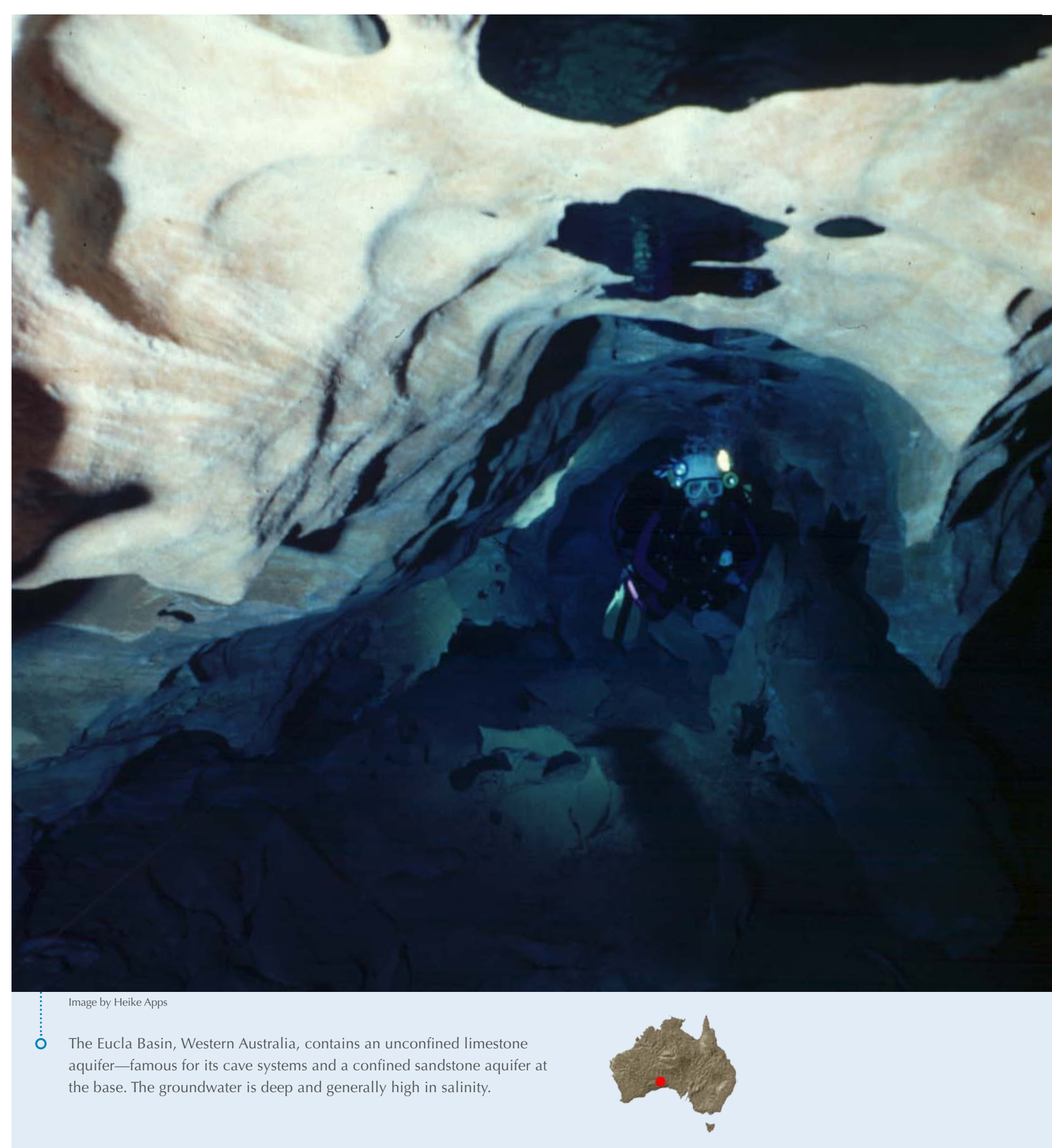



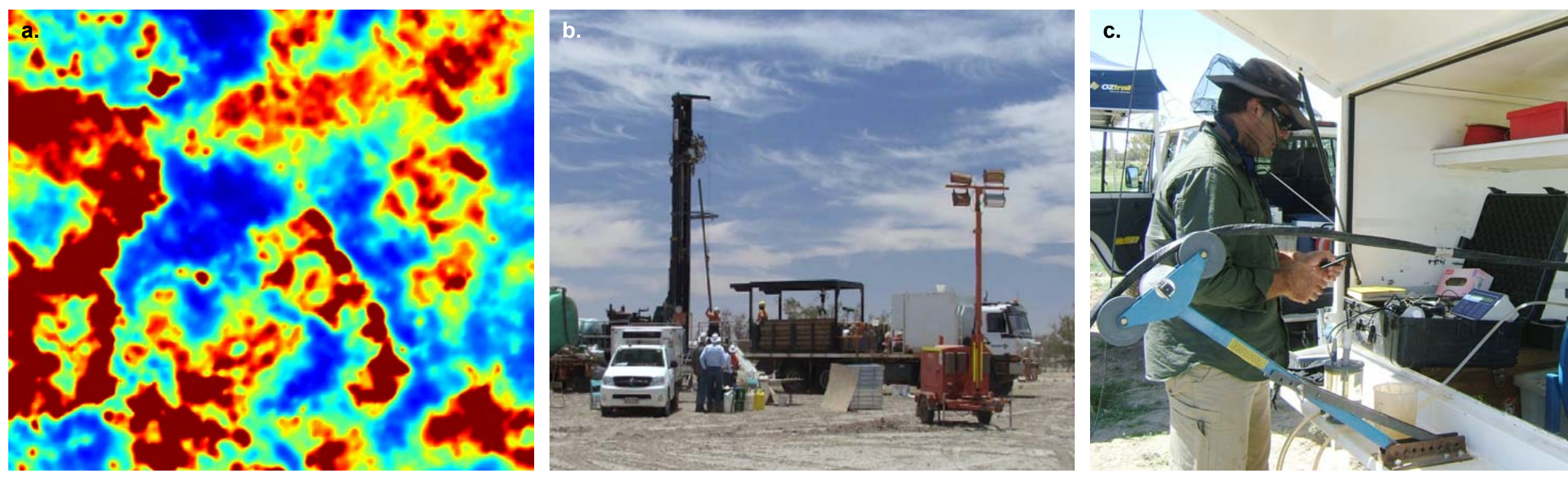

Figure 7.24: The Broken Hill Managed Aquifer Recharge project-an example of a geoscience systems-based approach, including geophysics, geomorphology, stratigraphy, sedimentology, geochemistry and hydraulics to understand groundwater systems. (a) Regional airborne electromagnetic survey over part of the Broken Hill area. (b) Sonic drilling to retrieve high-quality core in unconsolidated sediments and construct monitoring bores. (c) Comprehensive sampling and chemical analysis of geological material and pore fluids. (d) Downhole geophysical logging, including gamma, conductivity and nuclear magnetic resonance. (e) Bathymetric surveys and riverbed sediment sampling of the Darling River to better understand stream-aquifer connectivity.

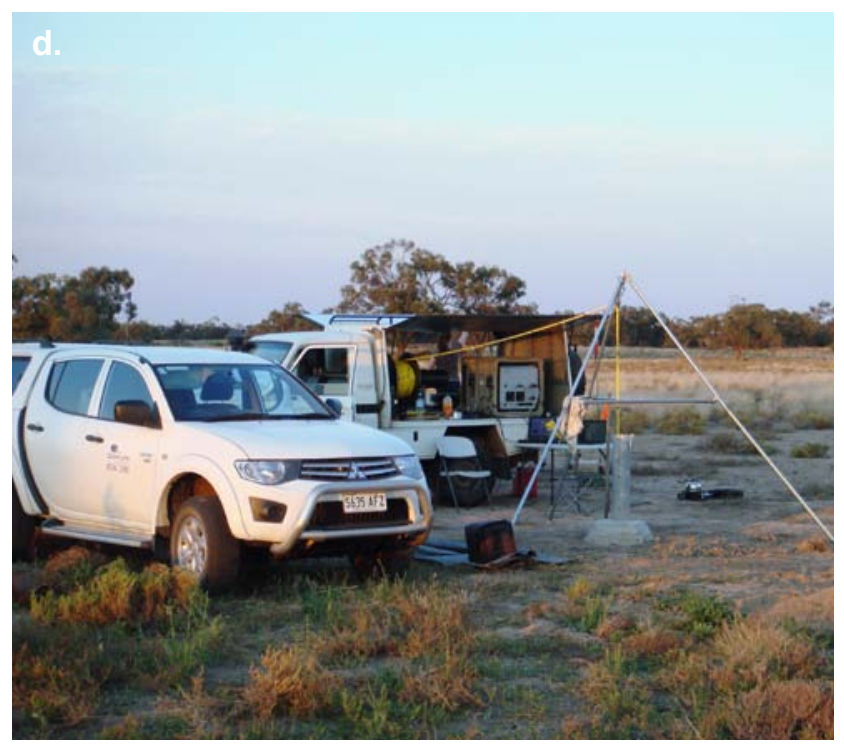

Each of the various tools that were applied provided a particular new insight into understanding the groundwater and aquifer resource for Broken Hill. Their true value and power are maximised when the tools are fully integrated into a geoscience systems-based approach in space and time. This approach shows us that geoscience innovations have a vital place in understanding groundwater

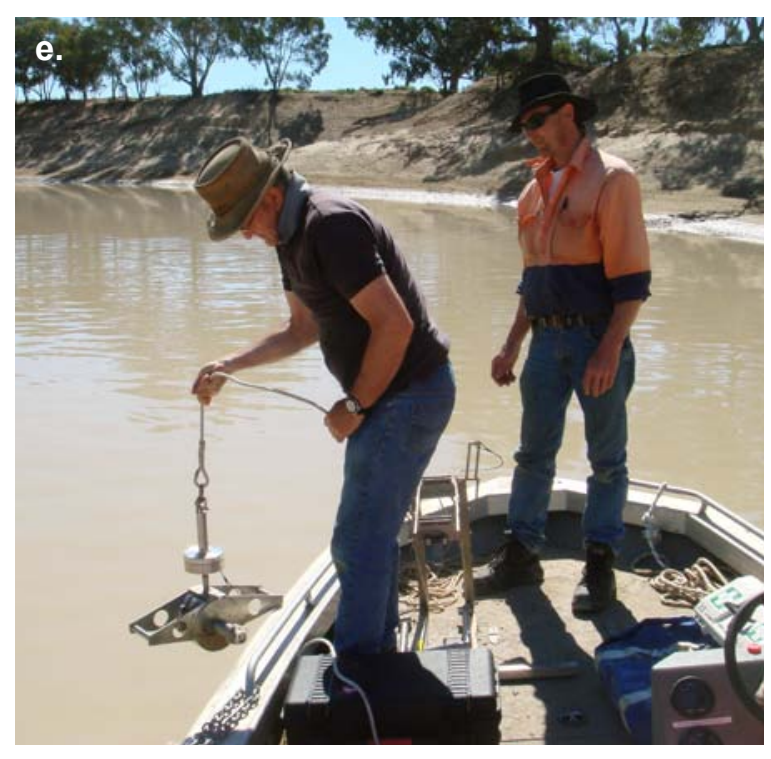

processes. Such a geoscience systems-based approach that integrates the latest advances in areas such as geological characterisation, landscape evolution, geophysics, hydraulics and hydrogeochemistry can make important inroads into unravelling the complexities of groundwater systems and contribute to critical land and water management issues. 

O Getty Images [A Campanile]

- Desiccation cracks in the dry bed of Lake Eyre, South Australia.

\section{Bibliography and further reading}

\section{Groundwater: a critical resource}

Australian Bureau of Statistics 2010. Water account Australia 2008-09, release 4610.0, ABS, Canberra.

Australian Bureau of Statistics 2010. Water use on Australian farms 2008-09, release 4618.0, ABS, Canberra.

Bayly IAE 1999. Review of how indigenous people managed for water in desert regions of Australia. Journal of the Royal Society of Western Australia 82, 17-25.

Box JB, Duguid A, Read RE, Kimber RG, Knapton A, Davis J \& Bowland AE 2008. Central Australian waterbodies: the importance of permanence in a desert landscape. Journal of Arid Environments 72, 1395-1413.

Brodie RS 2002. Putting groundwater on the map: a status report on hydrogeological mappingin Australia. In: Balancing the groundwater budget, proceedings of the International Association of Hydrogeologists conference, Darwin, 12-17 May 2002. www.connectedwater.gov.au/ documents/IAH02_HydroMap.pdf

Bureau of Meteorology 2011. Map of average conditions. www.bom.gov.au/climate/averages/maps.shtm

Cooper D \& Jackson S 2008. Preliminary study on indigenou water values and interests in the Katherine Region of the Northern Territory, CSIRO Sustainable Ecosystems, Darwin.
CSIRO 2008. Water availability in the Murray-Darling Basin. A report to the Australian Government from the CSIRO Murray-Darling Basin Sustainable Yields Project, CSIRO, Australia.

Faggion AE 1995. The Australian groundwater controversy 1870/1910. Historical Records of Australian Science 10, $337-348$

Gibson DL \& Wilford J 2002. Aspects of regolith and landscape of the Strathbogie-Caniambo-Dookie area: the need for interpretation of detailed geophysical datasets in the light of regional data and models. In: Victoria Undercover Benalla 2002 conference proceedings and fieldguide, Phillips GN \& Ely KS (eds), CSIRO Publishing, Victoria, 235-247.

Jacobson G \& Lau JE 1987. Hydrogeology of Australia, 1:5,000,000 scale map, Bureau of Mineral Resources, Geology and Geophysics, Canberra.

Lau JE, Commander DP \& Jacobson G 1987. Hydrogeology of Australia, Bulletin 227, Bureau of Mineral Resources, Geology and Geophysics, Canberra.

Murray-Darling Basin Authority 2010. Guide to the proposed Basin Plan: overview, Murray-Darling Basin Authority, Canberra. http://thebasinplan.mdba.gov.au

National Water Commission 2006. Australian water resources 2005, National Water Commission, Canberra. www.water.gov.au

Radke BM, Ferguson J, Cresswell RG, Ransley TR \& Habermehl MA 2000. Hydrochemistry and implied hydrodynamics of the Cadna-owie Hooray Aquifer, Great Artesian Basin, Bureau of Rural Sciences, Canberra. 
Report of the Second Interstate Conference on Artesian Water, Brisbane, 1914, AJ Cumming, Government Printer.

Roberts A \& Mountford C 1979. The dreamtime book, Rigby, Adelaide, 166-167.

Smith DI 1998. Water in Australia: resources and management, Oxford University Press, Melbourne.

Thomson DF 1962. The Bindibu Expedition III. The Bindibu. Geographical Journal 128, 262-278.

Weaver TR, Cartwright I, Tweed SO, Ahearne D, Cooper M, Czapnik K \& Tranter J 2006. Controls on chemistry during fracture-hosted flow of cold $\mathrm{CO}_{2}$-bearing mineral waters, Daylesford, Victoria, Australia: implications for resource protection. Applied Geochemistry 21, 289-304.

\section{Groundwater: a geological agent of change}

Boulton AJ \& Hancock PJ 2006. Rivers as groundwaterdependent ecosystems: a review of degree of dependency, iverine processes and management implications. Australian Journal of Botany 54, 133-144.

Bureau of Rural Sciences. Connected water — managing the linkages between surface water and groundwater, Australian Government, Canberra. www.connectedwater.gov.au

Fensham RJ \& Fairfax RJ 2002. In the Footsteps of J Alfred Griffiths: a Cataclysmic History of the Great Artesian Basin Springs in Queensland. Australian Geographical Studies: $40,210-230$

Fitzpatrick R \& Shand P 2008. Inland acid sulphate soils: overview and conceptual models. In: Inland acid sulphate soil systems across Australia, Cooperative Research Centre for Landscape Environments and Mineral Exploration Open File Report 249, 6-74.

Freij-Ayoub R, Underschultz J, Fangjun L, Trefry C, Henning A, Otto C \& McInnes K 2007. Simulation of coastal subsidence and storm wave inundation risk in the Gippsland Basin, CSIRO Petroleum Report 07-003, CSIRO Wealth from Oceans Flagship.

Hamilton S 2004. River-groundwater interactions in the Cudgegong Valley, Mudgee NSW. In: Conference proceedings, 9th Murray Darling Basin Groundwater Workshop, Bendigo, 17-19 February 2004

Hatton T \& Evans R 1998. Dependence of ecosystems on groundwater and its significance to Australia, occasional paper 12/98, Land and Water Resources Research and Development Corporation, Canberra.
Humphreys WF 2006. Aquifers: the ultimate groundwaterdependent ecosystems. Australian Journal of Botany 54 $115-132$

Johannes RE \& Hearn CJ 1985. The effect of submarine groundwater discharge on nutrient and salinity regimes in a coastal lagoon off Perth, Western Australia. Estuarine, Coastal and Shelf Science 21, 789-800.

Johnston SG, Slavich P \& Hirst P 2004. The acid flux dynamics of two artificial drains in acid sulfate soil backswamps on the Clarence River floodplain, Australia. Australian Journal of Soil Research 42, 623-637.

National Land and Water Resources Audit 2001. Australian dryland salinity assessment 2000: extent, impacts, processes, monitoring and management options, Australian Government, Canberra.

New South Wales Department of Environment and Climate Change 2009. Salinity audit_upland catchments of the New South Wales Murray-Darling Basin, NSW Departmen of Environment and Climate Change, Sydney.

O'Grady A, Carter J \& Holland K 2010. Review of groundwater discharge studies of terrestrial systems, CSIRO Water for a Healthy Country National Research Flagship.

Rengasamy P 2006. World salinization with emphasis on Australia. Journal of Experimental Botany 57, 1017-1023.

Sammut J \& Lines-Kelly R 1996. An introduction to acid sulfate soils, Australian Government Department of Environment, Sport and Territories \& Australian Seafood Industry Council.

Sinclair Knight Merz 2001. Environmental water requirements of groundwater dependent ecosystems, Environmental Flows Initiative technical report 2, Commonwealth of Australia, Canberra.

Stieglitz T 2005. Submarine groundwater discharge into the near-shore zone of the Great Barrier Reef, Australia. Marine Pollution Bulletin 51, 51-59.

Tomlinson M \& Boulton A 2008. Subsurface groundwater ecosystems: a review of their biodiversity, ecological processes and ecosystem services, Waterlines Occasional Paper no. 8 , National Water Commission, Canberra.

Tregoning P, Leblanc M, Ramillien G, Tweed S \& Fakes A 2009. Monitoring groundwater variations in the MurrayDarling Basin using space gravity measurements, Research School of Earth Sciences, Australian National University, Canberra.
Winter TC, Harvey JW, Franke OL \& Alley WM 1998. Groundwater and surface water a single resource, circular 1139, US Geological Survey, Denver.

\section{A groundwater future}

CSIRO 2009. Groundwater yield in south-west Western Australia, summary of a report to the Australian Government from the CSIRO South-West Western Australia Sustainable Yields Project, CSIRO, Australia.

CSIRO 2009. Water availability for Tasmania, report one of seven to the Australian Government from the CSIRO Tasmania Sustainable Yields Project, CSIRO, Australia.

CSIRO 2009. Water in northern Australia, summary of reports to the Australian Government from the CSIRO Northern Australia Sustainable Yields Project, CSIRO, Australia.

Dillon P, Pavelic P, Page D, Beringen H \& Ward J 2009 Managed aquifer recharge: an introduction, Waterlines Report Series no. 13, National Water Commission, Canberra.

El Saliby I, Okour Y, Shon HK, Kandasamy J \& Kim S 2009. Desalination plants in Australia, review and facts. Desalination 247, 1-14.

Geoscience Australia 2007. Direct-use of geothermal energy: opportunities for Australia, Geoscience Australia, Canberra.

Hoang M, Bolto B, Haskard C, Barron O, Gray S \& Leslie G 2009. Desalination in Australia, CSIRO Water for a Healthy Country National Research Flagship.

Leblanc MJ, Tregoning P, Guillaume R, Tweed SO \& Fakes A 2009. Basin-scale, integrated observations of the early 21 st century multiyear drought in southeast Australia. Water Resources Research 45, W04408.

Service RF 2006. Desalination freshens up. Science 313 , $1088-1090$.

UNESCO Centre for Membrane Science and Technology 2008. Emerging trends in desalination: a review, Waterlines Report Series no. 9, National Water Commission, Canberra. 